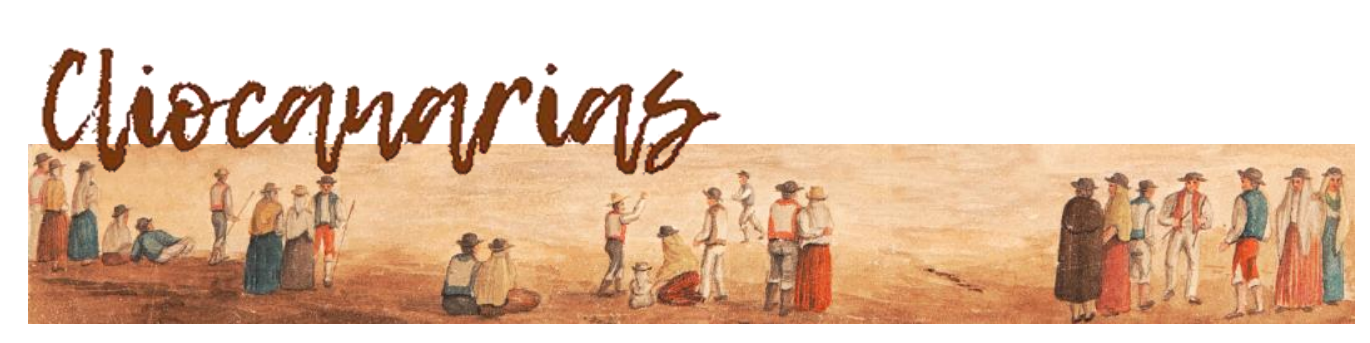

ISSN 2695-4494

https: / / doi.org/ 10.53335/cliocanarias.2021.3.28

\title{
DOCUMENTOS PARA LA HISTORIA DE LOS MONTES DE GRAN CANARIA: LAS ACTAS DE LA JUNTA DE MONTES (1788-1793)
}

\author{
DOCUMENTS FOR THE HISTORY OF MOUNTAINS OF GRAN \\ CANARIA: THE MINUTES OF THE JUNTA DE MONTES (1788-1793)
}

\section{Alexis Daniel BRITO GONZÁLEZ*}

\begin{abstract}
Resumen: La Junta de Montes de Gran Canaria fue un órgano creado con la intención de preservar lo que quedaba de los montes de dicha isla a finales del siglo XVIII. El libro de actas de dicha Junta es un instrumento interesante y novedoso para comprender las acciones emprendidas por la misma, dada la escasez de fuentes documentales que se conservan del cabildo grancanario en el Antiguo Régimen.
\end{abstract}

PALABRAS ClaVE: Gran Canaria, montes, libro de actas, junta, siglo XVIII.

ABSTRACT: The Junta de Montes of Gran Canaria was a council created with the intention of preserving what was left of the mountains of that island at the end of the 18 th century. The minute book of this council is an interesting and new instrument to understand the actions undertaken by it, given the scarcity of documentary sources that are preserved of the Gran Canaria council in the Old Regime.

KEYWORDS: Gran Canaria, forest, minute book, council, eighteenth century.

\section{Introducción}

Tras la finalización de la conquista, se implantó en las islas una sociedad que algunos investigadores han denominado como una "civilización de la madera " ${ }^{1}$. Las condiciones fisicas y geográficas del archipiélago canario que, a comienzos del siglo XVI, contaba con una importante cubierta forestal y una reducida población así como la carencia de fuentes energéticas, con la excepción hecha de la madera, propició la explotación intensiva de los bosques de laurisilva y pinares, sobre todo en las islas de realengo. El aprovechamiento de los montes fue de tal calibre que bien pronto saltaron las alarmas y en las ordenanzas del Concejo de Gran Canaria de 1531 se desarrolló un título de exclusivamente a las montañas y guardas de ellas, estableciendo una serie de

\footnotetext{
* Doctor en Historia y archivero. C. e.: adbg70@yahoo.com

${ }^{1}$ LOBO CABRERA, Manuel; Germán SANTANA PÉREZ, Germán; Ángel Luis RODRÍGUEZ PADILLA: Los usos de la madera: recursos forestales en Gran Canaria durante el siglo XVI, Las Palmas de Gran Canaria, 2007.
} 
medidas preventivas, como la interdicción de sacar madera sin licencia de la justicia y regimiento de la isla, la prohibición de la entrada de ganado (excepto yeguas y puercos) a la Montaña de Doramas, al Monte Lentiscal y al pinar, o la de hacer carbón o ceniza en cualquiera de dichos montes ${ }^{2}$. No obstante, la falta de fuentes de documentación originales, como los libros de actas del Cabildo de Gran Canaria, por ejemplo, nos impide conocer si estas medidas fueron efectivas, así como el cumplimiento y grado de implicación de la propia institución.

En las últimas décadas, la historiografía canaria ha desarrollado un especial interés por analizar la evolución de los montes en el archipiélago. Los primeros estudios a gran escala centrados en la propiedad pública de la tierra, como el de Suárez Grimón (1987) para Gran Canaria o la tesis doctoral de Núñez Pestano (1989) para Tenerife, ya incidieron en que una de las causas de la deforestación fueron las ocupaciones ilegales de tierras concejiles propiciadas por la retirada del mercado de estas. Sin embargo, la producción bibliográfica es desigual según la isla que analicemos; la profusión de fuentes documentales en la isla de Tenerife, donde podemos destacar, por ejemplo, la publicación de las actas del Cabildo de Tenerife en la colección Fontes Rerum Canariarum del Instituto de Estudios Canarios ha posibilitado la realización de numerosas investigaciones de las cuales debemos citar el proyecto Historia de los montes de Tenerife 3 por su envergadura y exhaustividad.

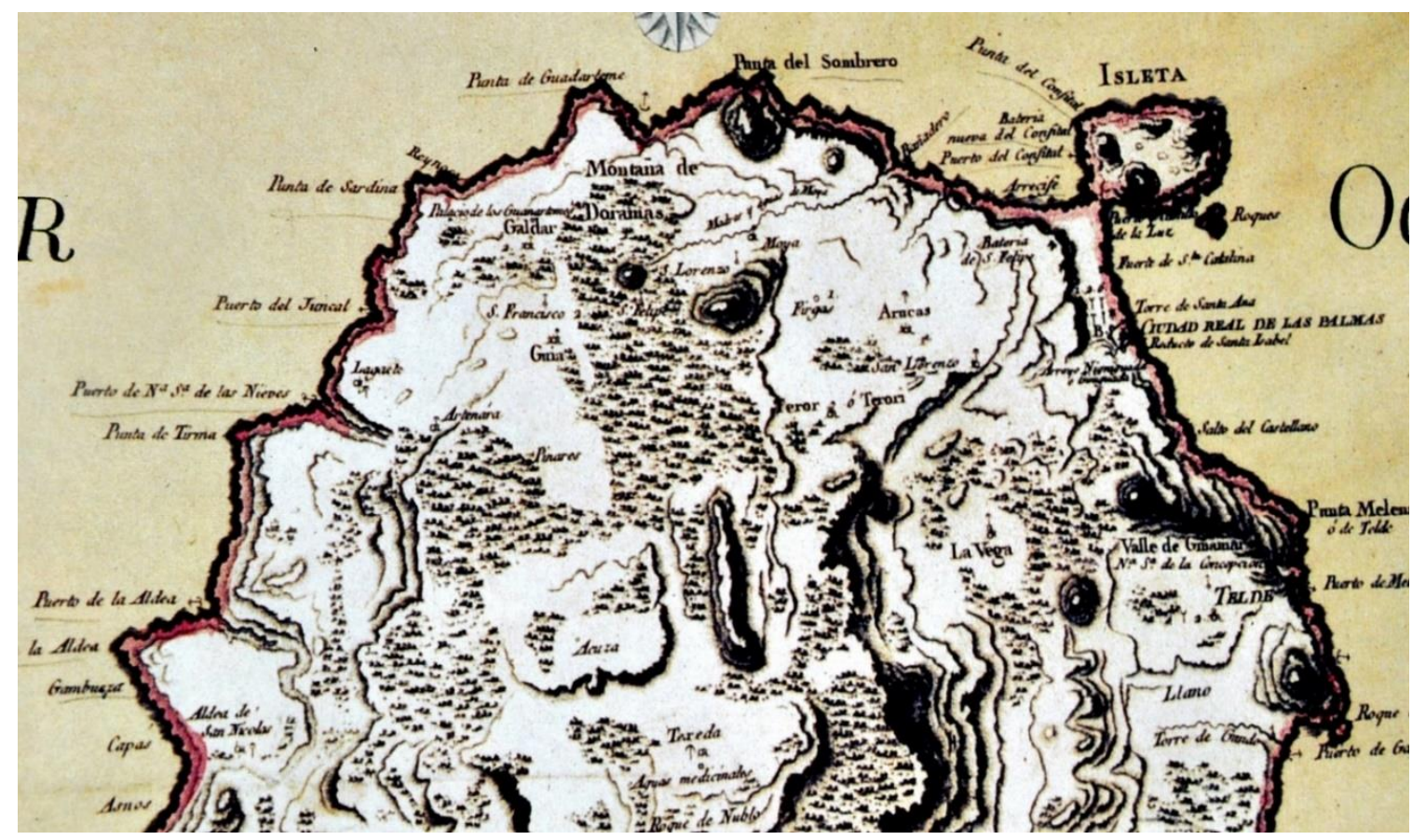

Mapa de la mitad septentrional de Gran Canaria en la segunda mitad del s. XVIII, formado a partir del mapa de D. Tomás López, en el que se aprecian los Pinares y el Monte de Doramas [TOUS MELIÁ, Juan: Descripción geográfica de las islas Canarias (1740-1741), Santa Cruz de Tenerife, 1997, p. 153].

2 MORALES PADRÓN, Francisco: Ordenanzas del Concejo de Gran Canaria (1531). Sevilla, 1974, p. 134.

${ }^{3}$ Los resultados de dicho proyecto se publicaron en la obra colectiva: QUIRANTES GONZÁLEZ, F. [et al.]: Los montes de Tenerife a través de su historia, La Laguna, 2011. 
Algo similar ocurre para la isla de La Palma, donde la conservación de los libros de actas del Cabildo insular, así como de otras importantes fuentes primarias, ha permitido analizar la trayectoria histórica de sus montes, destacando los trabajos que le ha dedicado Pedro C. Quintana Andrés, entre otros.

$\mathrm{Y}$ es que la falta de documentación, tanto primaria como secundaria, ha constituido un auténtico obstáculo para la investigación de los montes en la tercera isla de realengo. Tanto el ataque de Van de Does de 1599 como el incendio de las casas consistoriales en 1842 fueron dos golpes decisivos que se añadieron a siglos de desidia en la conservación del archivo municipal. Sin embargo, y gracias al esfuerzo de diversos autores como el profesor Suárez Grimón con su citada obra sobre la propiedad pública, vinculada y eclesiástica, podemos tener un acercamiento más o menos preciso sobre la evolución de los mismos.

Por este motivo, el análisis exhaustivo de cualquier documento referente a los montes de Gran Canaria resulta de especial interés y, no por conocido, ha sido suficientemente analizado. En este sentido, presentamos en este trabajo las actas de la Junta de Montes que se creó a finales del siglo XVIII en Gran Canaria como un último recurso para evitar la desaparición de los montes de la isla, y que se puede entender como una continuación del estudio que realizamos sobre el Reglamento de 1788 que, aprobado por la Real Audiencia, dio origen a esta Junta y se convirtió en su norma de funcionamiento.

\section{La Junta de Montes}

Si bien existía una preocupación latente en determinados sectores sociales por el estado de los bosques en Gran Canaria, fue en las últimas décadas del siglo XVIII cuando saltaron las alarmas, pues a las usurpaciones de tierras - tanto en las tierras de realengo como en los montes- se unían las roturaciones en sus linderos para dedicarlas al cultivo, además del abandono y dejadez en el cuidado de los montes públicos. A lo largo de 1787, el síndico personero D. Pedro Bravo presentó diversos memoriales sobre este tema y la necesidad de conservación de lo que quedaba aún de los ya agonizantes montes grancanarios. El 17 de diciembre de ese año se realizó un cabildo general sobre esta cuestión con la presencia del corregidor D. Vicente Cano, en la que el síndico personero D. Francisco de Paz Ascanio presentó la propuesta de crear una Junta que tratase en profundidad sobre este problema. Ante la indecisión del Cabildo, la Real Audiencia ordenó, mediante un auto de 22 de diciembre, la creación de la Junta para la elaboración de una propuesta, que se llevó a cabo antes del fin del mes de enero de 1788.

La Junta presentó su proposición en el cabildo de 7 de febrero de 1788, la cual se articulaba en veintitrés puntos que contenian diversos aspectos sobre la conservación, las penas, los replantos y la vigilancia de los montes, y que conllevó la queja del corregidor por considerarlo una intromisión en sus funciones. El texto fue debatido en el cabildo de 13 de febrero y finalizó con la inclusión de cuatro puntos (extendiendo el texto final a veinticinco) a propuesta del regidor D. Isidoro Romero y Ceballos, que estaban centrados principalmente en cuestiones sobre la Montaña de Doramas y su entorno, tras lo cual se elevó a la Real Audiencia para que diese su parecer. En un informe del 
2 de abril, el fiscal del tribunal, Yzuriaga, mostraba su conformidad con el mismo añadiendo algunas modificaciones en lo relativo a las licencias de corte de madera, penas y nombramiento de guardas, aprobado todo ello por la Audiencia el 3 de abril y ratificado el 17 de junio de 1788 .

En cuanto a sus componentes, los inicialmente nombrados por la Real Audiencia para la redacción del Reglamento fueron los regidores D. Francisco de León y D. Pedro Mackintosh, junto a los diputados José Arbonies y Nicolás Massieu $^{4}$. Sin embargo, el repentino fallecimiento de D. Pedro Mackintosh en mayo de 1788 y el fin del período electo como diputado de D. José Arbonies provocaron su sustitución por otros miembros del Cabildo insular, en concreto por el regidor D. Isidoro Romero y Ceballos y el diputado D. Andrés Cabrera, los cuales fueron aprobados por auto del tribunal de 28 de junio de 1788 .

No fueron los únicos que pasaron por la Junta durante estos años; así, el regidor D. Francisco de León fue reemplazado por el también regidor D. Manuel del Río, mientras que entre los diputados del común y síndicos personeros el movimiento fue mayor, pues podemos citar que pasaron por la Junta Andrés Cabrera de León, el capitán D. Francisco de Laysequilla, Ignacio Díaz, Andrés Barreto y D. Agustín Márquez (todos ellos diputados del común). así como los sindicos personeros D. José Gómez, D. Juan Reyes Cabrera, D. Sebastián de Quintana y Juan de Cala.

\section{E1 libro de actas (1788-1793)}

El documento que ofrecemos en esta aportación se conserva en el fondo del Ayuntamiento de Las Palmas de Gran Canaria que se encuentra en el Archivo Histórico Provincial de Las Palmas, en concreto dentro de la serie Intereses Generales $^{5}$. Se trata de un libro de actas que consta de 383 folios que abarcan un período cronológico comprendido entre los años 1788 y 1793 . No obstante, hemos de precisar que los primeros cuarenta y cinco folios del mismo se centran en la gestación del Reglamento y de la Junta de Montes mediante la certificación del escribano mayor del Cabildo de la isla desde el cabildo celebrado el 13 de diciembre de 1787. En este se notificaba que la Real Audiencia devolvía al mismo el conocimiento económico y gubernativo de los montes de la isla hasta el celebrado el 1 de julio de 1788, en el que se atiende otro auto de 28 de junio de la misma Audiencia por el cual se aprobaba el nombramiento de los diputados de la Junta y, por tanto, ordenaba que se procediese a la ejecución de lo establecido6.

En definitiva, las actas propiamente dichas comienzan realmente en el folio cuarenta y siete del libro, a partir del cual se redactan ciento cincuenta y tres actas de dicha Junta extendidas cronológicamente entre el 29 de julio de 1788

${ }^{4}$ BRITO GONZÁLEZ, Alexis D.: «El Reglamento de montes de 1788. Un proyecto frustrado para salvar los bosques de Gran Canaria a finales del Antiguo Régimen", en Vegueta n. ${ }^{\circ}$ 19, (2019), p. 495.

${ }^{5}$ La referencia completa sería la siguiente: (A)rchivo (H)istórico (P)rovincial de (L)as (P)almas, Fondo del Ayuntamiento de Las Palmas de Gran Canaria, eerie Intereses Generales, legajo 1, expediente 4.

${ }^{6}$ El estudio que realizamos sobre el Reglamento de montes de 1788 nos exime de transcribir o extractar los primeros cuarenta y cinco folios (BRITO GONZÁLEZ, Alexis D.: "El Reglamento de montes de $1788 \ldots$, art. cit.). 
y el 16 de septiembre de 1793, un periodo de algo más de cinco años. Sin embargo, hemos de advertir que este documento no incluye todo el período activo de la Junta, pues esta fue disuelta por auto de la Real Audiencia de 14 de abril de 1795, un año y medio más tarde del fin de este libro de actas, y que durante este tiempo ese organismo continuó su actividad, como sabemos por fuentes indirectas ${ }^{7}$.

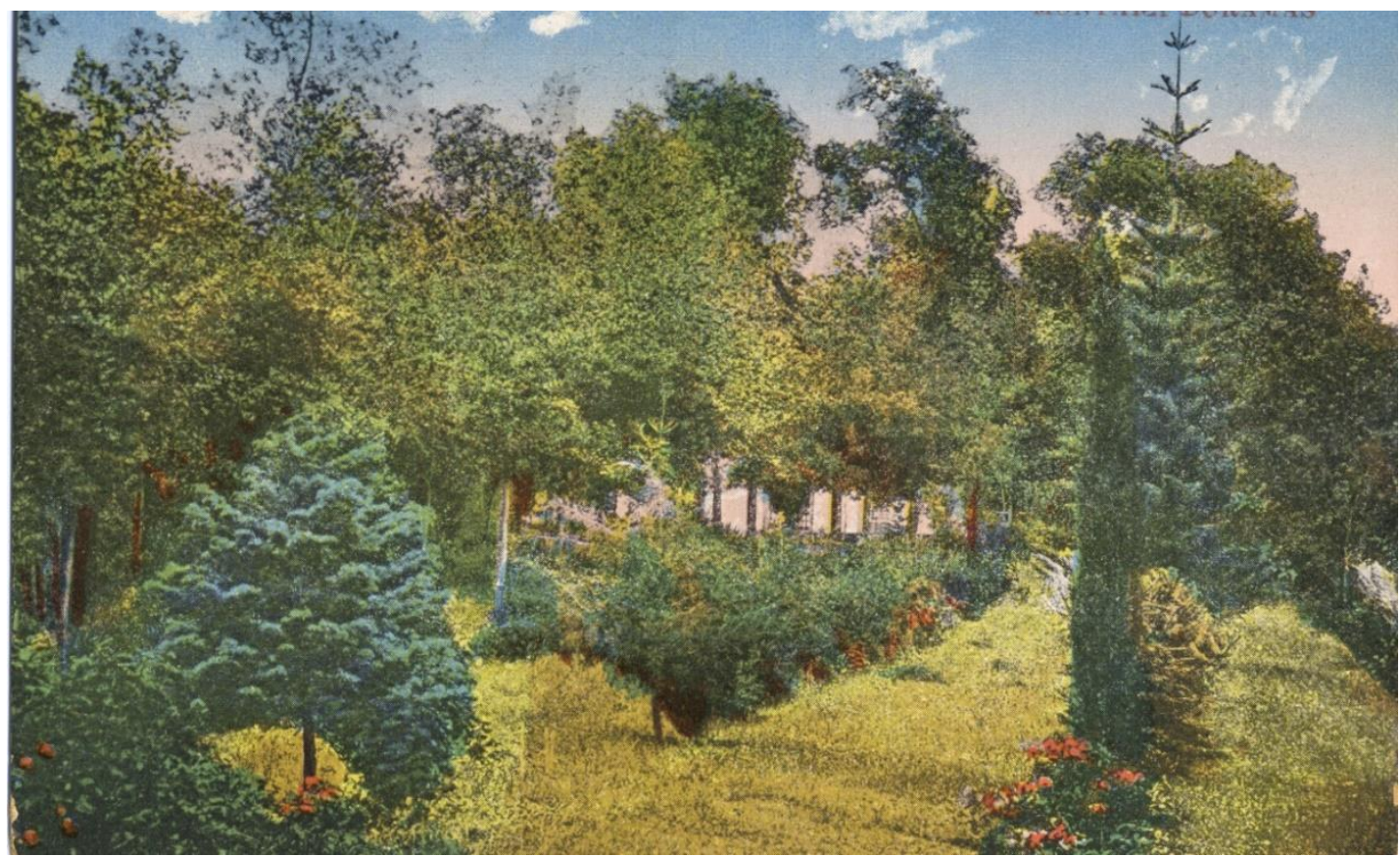

Monte Doramas (principios del s. XX (Fondo Fedac)

Las actas recogen un amplio abanico de temas, pero se pueden sintetizar en tres grandes grupos: en primer lugar, la actividad propia de la Junta, como nombramientos de guardas, recepción y cumplimiento de autos y decretos de la Real Audiencia, así como la presentación de informes y exposiciones propias; en segundo lugar, la consulta y lectura de informes o correspondencia con otras instituciones (como la Real Audiencia o la Real Sociedad Económica de Amigos del País) sobre el estado de los montes de las islas y los posibles remedios para mejorarlos; en tercer lugar, la tramitación y concesión o no de las licencias de cortes de madera de los montes. Salvo contadas excepciones, se trata de actas no muy extensas, en las que se suelen tratar uno o dos temas, ya que por lo general muestran una periodicidad irregular en cuanto encontramos meses en los que se pueden reunir en tres y cuatro ocasiones mientras que en otros solo lo hacen en una.

\section{Normas de edición}

Para facilitar tanto la lectura como la comprensión del texto, en ocasiones denso con la inclusión de autos de la Audiencia, escritos de los guardas y correspondencia con otras instituciones, por citar algunos ejemplos, se ha

7 Acuerdo de la Junta de Montes y oficio de remisión a la Audiencia, sobre concesión de licencias de cortes de madera en el pinar y Montaña de Doramas al mayordomo de San Matías de Artenara; a Francisco Miguel Déniz, vecino de Las Palmas; al teniente coronel Andrés Russell; y a Domingo Sánchez, vecino de Tirajana (AHPLP, Real Audiencia de Canarias, Procesos civiles y penales, expdte. 15.389 (1794). 
realizado un extracto de las actas conservando la información fundamental de las mismas, en especial nombres de personas, de lugares, calles, embarcaciones, etc.

Sin embargo, y debido al enorme interés que abarca el contenido de algunas $\operatorname{actas}^{8}$, se ha procedido a la transcripción de su texto mediante las siguientes normas:

a) Se coloca el texto transcrito en cursiva para diferenciarlo del resto del texto que lo pueda acompañar.

b) Se mantiene la grafia original con las excepciones siguientes: normalización del uso de puntuación y tildes y no se transcriben las consonantes dobles al principio de las palabras.

c) Desarrollo de las abreviaturas, sin señalar en cursiva las letras que no aparecen.

d) Los números se transcriben en su forma romana o arábiga.

e) Unión o separación de palabras con criterios actuales.

f) Las letras o palabras agregadas al texto, ya sea porque faltaron en el original o a causa del deterioro del soporte, se señalan entre corchetes.

g) Las palabras interlineadas o en los márgenes y las adiciones al texto se señalarán colocando el texto entre líneas tendidas convergentes hacia abajo: "e yo \Juan/".

h) Las palabras tachadas, corregidas y otras anomalias se señalan en nota.

i) En el caso de textos de cierta extensión que ocupan varios folios se ha procedido a indicar el foliado (para facilitar su localización en la fuente original); y el cambio de página se anuncia de acuerdo a esta fórmula: / / ${ }^{\text {vto. }}$

\section{Bibliografia}

BRITO GONZÁLEZ, Alexis D.: «El Reglamento de montes de 1788. Un proyecto frustrado para salvar los bosques de Gran Canaria a finales del Antiguo Régimen", en Vegueta, n. ${ }^{\circ}$ 19, 2019, pp. 487-511.

EXPÓSITO LORENZO, Ma Gloria, y Pedro C. QUINTANA ANDRÉS: «Deforestación y contrabando: los montes palmeros a fines del Antiguo Régimen (1799-1830)", en X Coloquio de Historia Canario-Americana (1992), vol. 2, pp. 365-384.

FERNÁNDEZ PELLO, L. [et al.]: "La importancia de los deslindes en el conocimiento de la evolución de la superficie forestal en la isla de Tenerife", en Estudios Canarios. Anuario del Instituto de Estudios Canarios, n. ${ }^{\circ} 49$ (2004-2005), pp. 197-228.

\footnotetext{
8 Entre esos documentos interesantes se encuentran la propuesta del regidor D. Isidoro Romero para añadir al Reglamento de Montes (acta 7); la exposición de D. Francisco de León sobre lo ocurrido en el Monte Lentiscal al guarda con intrusos (acta 16); el memorial del teniente de guarda en la Montaña de Doramas Juan de Almeida sobre amenazas (acta 44); la correspondencia con la Real Sociedad Económica de Amigos del País (actas 45, 60, 61, 79, 87, 95); la instrucción del regidor D. Isidoro Romero para el desempeño de los guardas (acta 75); informes de los guardas (actas 78, 83, 109, 114); o la representación que realizó el diputado D. Andrés Cabrera sobre la Montaña de Doramas (acta 147), por citar los de mayor extensión.
} 
GONZÁLEZ DE CHÁVEZ MENÉNDEZ, Jesús: "Notas para la historia de los montes de Gran Canaria en el tránsito del antiguo al nuevo régimen", en Homenaje a Jesús Arencibia, 1982, pp. 93-106.

GONZÁLEZ GARCÍA, Esther M.: "Los montes en la historia de las islas", en $I X$ Coloquio de Historia Canario-Americana (1990), vol. 2, pp. 129-146.

LOBO CABRERA, Manuel, Germán SANTANA PÉREZ, y Ángel Luis RODRÍGUEZ PADILLA: Los usos de la madera: recursos forestales en Gran Canaria durante el siglo XVI, Las Palmas de Gran Canaria, 2007.

LUIS GONZÁLEZ, Manuel: "La evolución histórica de los paisajes vegetales de la vertiente norte de Tenerife", en Revista de Historia Canaria n. 186 (2004), pp.167-188.

MORALES PADRÓN, Francisco: Ordenanzas del Concejo de Gran Canaria (1531), Sevilla, 1974.

NÚÑEZ PESTANO, Juan Ramón: La propiedad concejil en Tenerife durante el Antiguo Régimen: el papel de una institución económica en los procesos de cambio social. Tesis doctoral inédita, La Laguna, 1989.

QUINTANA ANDRÉS, Pedro C.: Los montes palmeros en la Edad Moderna (1493-1850). Comunidad rural, conflictos sociales y explotaciones forestales. Las Palmas de Gran Canaria, 2008.

QUIRANTES GONZÁLEZ, F. [et al.]: Los montes de Tenerife a través de su historia. La Laguna, 2011.

RODRÍGUEZ BENÍTEZ, Pedro José: Hambre de tierras. Atraso agrario y pobreza en La Palma: una crisis de larga duración. Santa Cruz de Tenerife, 2004.

SUÁREZ GRIMÓN, Vicente: La propiedad pública, vinculada y eclesiástica en Gran Canaria en la crisis del Antiguo Régimen. Las Palmas de Gran Canaria, 1987. 


\section{ACTAS DE LA JUNTA DE MONTES}

\section{8/Julio/29. Canaria.}

Junta con asistencia de D. Francisco de León y Matos, D. Isidoro Romero y Zevallos, regidores, y D. Andrés Cabrera, diputado del común; ausentes D. Nicolás Massieu y el síndico D. José Gómez por hallarse en el campo.

Se acuerda nombrar por guarda del Monte Lentiscal a Agustín Velázquez, vecino de Canaria; por guardas de la Montaña de Doramas a D. Luis Falcón, vecino de Teror, y a José Almeida, vecino de Guía; y por guarda de los Pinares a D. Antonio Tobar Falcón, vecino de Tejeda. Y se pase testimonio de los nombramientos a la Real Audiencia.

D. Francisco de León exhibe un auto de la Real Audiencia de 8 de Julio de 1788 en el que manda se prevenga al corregidor que procure evitar los perjuicios que se enuncian acerca de la desolación del Monte Lentiscal.

Se exhiben las denuncias dadas por Agustín Francisco, por indisposición de Antonio Rodríguez, sobreguarda de la Real Audiencia, el día 10 del corriente contra José Ríos y Antonio Mújica. Respecto a ellas, y teniendo noticia la Junta de estarse procediendo contra los reos con el mismo motivo, se pongan en legajo con las antecedentes.

\section{2}

\section{8 / Agosto/ 13. Canaria.}

Junta con asistencia de D. Isidoro Romero y Zevallos, regidor perpetuo, y D. Andrés Cabrera, diputado del común. Ausente el resto por hallarse en el campo, y excusado el señor síndico personero por algunos embarazos.

El escribano comunica que, habiendo escrito a los guardas electos en la junta anterior para que concurriesen ante el corregidor a recibir su título, se presentaron en esta ciudad pero el señor corregidor se habia negado a habilitarlos. Se acordó que el diputado del común pase oficio al corregidor suplicándole expida los títulos de los nombrados por esta Junta y aprobados por la Audiencia, y que si tiene motivos para no acceder a los deseos de la Junta los manifieste para que la Junta los pase a la Audiencia y no verse responsable de los daños que puedan ocasionarse a los montes.

\section{3}

\section{8/Septiembre/27. Canaria.}

Junta con asistencia de D. Nicolás Massieu y D. Andrés Cabrera.

Se presentaron tres memoriales. Uno de D. ${ }^{a}$ Ana Monteverde, vecina de Canaria, solicitando licencia para sacar de la Montaña de Doramas trescientas latas para composición de levantar las parras de su hacienda. Otro de D. José Tovar, clérigo presbítero, vecino de Gáldar, solicitando licencia para sacar de la Montaña de Doramas trescientas latas para composición de levantar las parras de su hacienda. Y otro memorial de D. Diego de Quintana, vecino de Gáldar, solicitando licencia para sacar de la Montaña de Doramas doscientas latas para composición de levantar las parras de su hacienda. 
Se acordó que, viniendo en la forma prescrita y mandada guardar por la Real Audiencia, se dará providencia, y el presente escribano, según se le tiene mandado, no admita memoriales en los términos prevenidos.

\section{4}

\section{8/Octubre/8. Canaria.}

Junta con asistencia de D. Isidoro Romero y Zevallos, regidor perpetuo, y D. Andrés Cabrera, diputado del común, y D. José Gómez, síndico personero.

Presentación por D. Isidoro Romero de un testimonio entregado por el escribano de acuerdo D. Dámaso de Hermosilla, que comprende la exposición del fiscal de Su Majestad de 1 de octubre y auto de la Real Audiencia de 3 de octubre sobre el expediente formado y relativo a la Montaña de Doramas. Y se acuerda se cumpla y se manden las cartas correspondientes a los tenientes de guardas antiguos a fin de que, en el término de ocho dias, remitan los títulos de tales a esta junta para pasarlos a la Audiencia; y que los guardas nombrados acudan en ocho dias a formalizar la aceptación y juramento y obtener los títulos competentes, y se le haga entrega de los respectivos capítulos del Reglamento formado para el reglamento de los montes para que los pongan en práctica en la parte que les toca.

D. Andrés Cabrera hace presentación de un testimonio entregado por mandato de la Real Audiencia por D. Francisco Martínez de denuncias dadas por D. Juan Antonio Domínguez, sobreguarda de la Montaña de Doramas, de los daños cometidos en ella. Se acordó se ponga en el legajo correspondiente, ya que el tribunal remitió lo mismo al corregidor.

Memorial de José Díaz, vecino de Guía, para sacar de la Montaña de Doramas las piezas de madera necesarias para la fábrica de una casa de acuerdo con la memoria firmada de José Gómez, carpintero. Se acordó se concede.

Exposición del síndico personero sobre la comunicación de las multas presentadas en la Audiencia y que se haga igual a la Junta.

\section{5}

\section{8/Octubre/16. Canaria.}

Junta con asistencia de D. Isidoro Romero, regidor perpetuo, y D. Andrés Cabrera, diputado del común, y D. José Gómez, sindico personero.

Memoria de D. Luis Falcón, vecino de Teror, sobre que ha sido nombrado guarda mayor de la Montaña de Doramas, para lo cual tiene hecho juramento, pero que es imposible de cumplir por hallarse habitualmente impedido por dolores de ciática, que su mujer D. ${ }^{a}$ Francisca Bárbara Falcón también se halla con indisposiciones habituales, al tiempo que tiene distintos terrenos, tanto en Teror como en Tejeda, que necesitan de su presencia en aquellos huecos que experimenta mejoría, y ser diputado del pósito de Teror y últimamente ser secuestrario de los bienes de los herederos del capitán D. Antonio Enríquez, por lo que pide se le exonere de dicho empleo. Se acuerda pase a la Real Audiencia por haberlo confirmado este tribunal y que resuelva el mismo. 
Memorial de Gregorio Miranda, vecino de Gáldar y dueño del barco La Concepción, por el que solicita licencia para cortar madera de la Montaña de Doramas, según consta de la memoria adjunta que presenta del maestro que lo ha de componer. Adjunta memoria de 13 de octubre de Blas de Miranda, oficial de ribera, vecino de Gáldar residente en Canaria, con la madera que necesita: una quilla, dos rodas, quince brazos redondos para ligazón dobles, quince chim ${ }^{\text {tos }}$ dobles, seis cintas dobles, quince artes dobles de popa y proa, dos piezas de bancos dobles, cuatro latas dobles de popa y proa, un yugo doble de proa, un albañil para proa, un banco de trancar para popa y una gusarda9 Se acordó conceder la licencia.

\section{6}

1788/Octubre/21. Canaria.

Junta con asistencia de D. Isidoro Romero, regidor perpetuo, y D. Andrés Cabrera, diputado del común.

El escribano expone que pasó a la Real Audiencia a presentar la consulta de la renuncia de D. Luis Falcón, y el tribunal admitió la excusa, por lo que la Junta nombra a D. Francisco Domínguez Falcón y Naranjo, vecino de Teror en San Isidro, como teniente de guardamayor de la Montaña de Doramas, y se pase a la Real Audiencia para su aprobación.

\section{7}

\section{8/Octubre/31. Canaria.}

Junta con asistencia de D. Isidoro Romero, regidor perpetuo, y D. Andrés Cabrera, diputado del común.

Propuesta hecha por D. Isidoro Romero, quien dice que habiendo entendido que el escribano maior de Cavildo don Carlos Vázquez ha pasado a la Montaña de Oramas a ebacuar ciertos deslindes por mandato del superior tribunal de la Real Audiencia, le parese que esta es una ocación oportuna para el deslinde y amojonamiento general de ella, sin el qual estará siempre aventurada la conzerbación de tan presiosa piesa; y que para ponerlo en ejecución se suplique al referido tribunal se sirba mandar pase a aquella parte adonde se halla dicho escribano el maestro alarife de la ciudad con orden de que en todos aquellos parajes en donde dicha montaña no tenga por lindero barranco, barranquillo, roca o risco de nombre conosido, simiente por mojón una gran piedra sobre un masiso de cal y piedra que haia llenado el hueco de un simiento de tres cuartos de hondo y una vara en cuadro a distancia que desde uno se descubra el otro $y$ desde esotro exotro y asi subsesibamente, a fin no solo de dar a conocer expresamente los limites de dicha montaña a todos los que se asercaren a ella, sino de impedir para lo futuro dudas, equivocaciones y usurpaciones a no mediar una grande osadia de parte de los que los intentasen, porque los simientes de cal son unas señales nada equivocas por donde se descubren y sacan los rastros de muy antiguos edificios y padrones de los confines de provincias, exponiendo a continuación los siguientes párrafos para añadir al nuevo plan

${ }^{9}$ Se trata de buzarda.

https://doi.org/10.53335/cliocanarias.2021.3.28

10/Cliocanarias, ISSN 2695-4494, n. ${ }^{\circ} 3$ (2021), pp. 1-128, La Laguna (Canarias) 
aprobado del gobierno de los montes y para breve instrucción de los guardas que se remiten a la Real Audiencia.

Párrafo $1 .^{\circ}$. Para que los carboneros no causen ynsendios haciendo el carbón adbitrariamente en los parajes que les parese como hasta aqui se les ha tolerado, se les señalará por los guardas dos o tres puestos fijos y determinados a bastante distancia de la primera fila de árboles y malesa, en donde únicamente puedan haser el carbón conduciendo a dichos parajes la leña de que //60rto se ha de haser con arreglo a lo que se previene en el párrafo $2 .^{\circ}$ y $3 .^{\circ}$ de dicho nuebo plan; esto es, que haia de ser presisamente de leña de breso, y en su defecto de retales o desechos secos aunque sean de otros árboles, con tal de que se tomen con interbención de guarda. Y el mismo señalamiento de puestos se habrá de haser en el pinal, assi para el dicho carbón que alli se hiciese como para hacer la brea; $y$ aunque en unos $y$ otros montes es tan presisa esta precaución, lo es sin duda con más nesesidad en el dicho pinal por la prontitud con que prenden la [h]ojarasca y pinochas de que está cubierto el terreno, y de cuios descuidos se han tenido tristes esperiencias insendiándose dicho pinal casi todos los años, y por tanto se debe mirar con mucha seriedad este asunto, assí pasa residenciar al guarda que no lo selare como para cargar la pena que impone el capitulo 23 de la citada real cédula de montes, que se deberá aplicar también a los dichos carboneros y brederos que asi en la montaña como en dichos pinales se les tomase haciéndolo en otros parajes fuera de los que se les señalare, como se previene en este párrafo. Y por lo que hase a la leña de que habrán de haser //60 vto el carbón y brea en el pinal, se les señala y permite para ello los retales de los pinos que se hayan cortado para obras y las sepas y troncos cortados supuesta la interbención de los guardas, quien para estos fines en ninguna forma permitirá se derribe pino por el pie.

$2 .^{\circ}$. Habiéndose entendido de que los carboneros no se contentan solamente con el daño que hacen cortando árboles por el pie si no es arrancando las sepas y raices, se les prohibirá vajo las penas del capitulo 22 y 23 de dicha real cédula de montes el corte de árbol de pie y arranque de cepa verde, permitiéndose nobstante con permiso del guarda el arranque de las que estén enteramente secas y de aquellas mui corpulentas que haian quedado de algún árbol biejo cortado, pues las tales aunque retoñen es sin fuerza y se malogra el que en su lugar se replante uno nuebo que en lo adelante pueda dar probecho; y la prohibición de cortar árbol de pie se ha de entender no solo de los que llaman brabos, que son los más biejos, sino es de los tallares, que son los de media edad y los nuebesitos, comprehendiéndose //61rto en la misma pena los que rosaren la malesa que se hase de los brotes de las raises de los mismos árboles, pues esta es muy combeniente para el abrigo de los arbolitos nuebos que nacen de la vaga, los que quedan rosados a flor de la tierra quando se permiten semejantes talas; pero vien podrán entresacar la leña de zarza y helechos y de otros arbustos que más vien dañan que aprobechan a los arbolitos nuebos, mas ha de ser con prebio conocimiento de los guardas.

3. . Siendo como es tan perjudicial la libre facultad que hasta aqui han tenido los labradores de cortar por si o por fragueros sin interbención de los guardias las piesas del uso de la labranza, haciendo por impericia gravisimo 
daño, derribando árboles sin premeditación, precisión, economía y aprobechamiento $y$, lo peor de todo, sin dejar la horca y pendón que se prebiene en el párrafo $6 .^{\circ}$ del nuebo plan de montes, conforme al espiritu del capitulo 18 de la real cédula de montes, se debe prohibir para cortar semejantes perjuicios a los dichos labradores y fragueros //61vto el que hagan dichos cortes sin la correspondiente lizencia y presencia de dichos guardas, vien que a los dichos labradores por el interés y fomento de la agricultura se les despachará gratis las licencias $y$ asistencia del guarda, jurando ser para usos propios quando pidan la licencia y no para vender y comerciar, pues en este caso habrán de pagar sus derechos. Y se deberán entender por piesas del uso de labranza: yugos, cabezas, timones, arados, trillos, palas, gambuesas para enserrar ganados, corchos para abejas, picas o astas, garrotes y orcones para serrería, parigüelas, corsas, plumas y soleras para andiamadas de fábricas y escaleras.

4. . Que quando las lizencias para cortes no exeda de quinze tijeras o de dose tiserones o de dose jubrones o de dos o tres tosas, se redusga a la mitad los derechos de las lizencias, pues las fábricas y reparos de los edificios se deben considerar como de primera nesesidad, y no parese justo se imposibilite sus progresos que tanto importa al Estado en la maior población; y por esta razón / /62rto se escuzan para adelante los más derechos que se han introducido en las lizencias después que las da la Junta, obserbándose para con el señor corregidor lo mismo que se ejecutaba quando las daba la ciudad plena; esto es, que con solo el memorial decretado de la Junta, de que se tomará razón en un libro separado que haia para ello, bastará para que el dicho señor corregidor despache la dicha Lizencia sin más autos ni diligencias prebias, y habrá presisamente de expresarse en ellas la sircunstancia de haberse de dejar orca y pendón en los árboles que no se nesesite cortar por el pie y la obligación de poner tres árboles o de contribuir con sinco reales de vellón por cada árbol de pie que se corte, según está acordado y aprobado en el citado nuevo plan, obserbándose por dichos guardas lo que en esta parte se les prebiene: esto es, poner la razón de los árboles que se cortasen al respaldo de la lizencia, que debolberán con exibo de los derechos percibidos por cada pie de árbol cada tres meses a dispocición de la Junta, que consultará con el superior tribunal los destinos que combenga mejor dar a dichos fondos, y en dicho tiempo la darán tambien de las //62vto nobedades que haian ocurrido en dichos montes, como también está acordado, y de las denuncias que haian hecho ante el señor corregidor.

5. . Para que la horca y pendón sea útil a los montes habrán de tener entendido los guardas que el gajo que se ha de dejar ha de ser de los más rectos $y$ enrramados, $y$ de ninguna manera de los colaterales retuertos ni mal sanos, pues entonces faltaria el fin y probecho de este método que consiste en hacer árboles de pie alto; $y$ por esta misma razón no permitirán el corte por el pie de árboles que no sean los más antiguos, para dar lugar los más nuebos a que crescan, enbarnescan y puedan serbir con el tiempo para obras maiores compreendidas en las clases de vigas y tosas.

6. ${ }^{\circ}$. Siendo mui digno de remedio el desorden con que los fragueros en el pinal pierden muchísimos pinos cortándolos con la hacha, bien dentro del corazón para descubrir la tea //63rto a quantos van encontrando por no caminar $y$ 
buscar los pinos ia sasonados y hechos, se les deberia aplicar la pena del capitulo 23 de la citada real cédula de montes; y lo mismo a los que para haser aros de queso y otras obras descortesan en sircunferencia los árboles que están de pie verdes, pues indefectiblemente se pierden, como repetidas esperiencias de musiur Duhaniel lo han demostrado.

7.'. Que dependiendo el adelantamiento de los árboles de haserse los cortes y limpia de ellos en la debida estación, se devería prohibir absolutamente la corta de maderas para barcos y edificios en todo el tiempo que no fuese desde mediado diziembre hasta mediado febrero, a exepción de una pieza mui presisa de timón, etc., que nesesite o haia perdido algún buque, assi nacional como extranjero, sin el qual no pueda seguir viaje, porque a los árboles el corte en otra estación que no sea la dicha los atrasa, quando por el contrario en esta, como es la sazón de estarse preparando para su empuje, brotan vigorosamente en la primavera; y es conforme al capitulo 10 de la citada real cédula de montes, pero esta limitación //63vto, que es combeniente a la montaña y monte, no es nesesaria en el pinal y demás árboles resinosos, pues estos jamás brotan una bes de cortados por el pie.

8. . Habiéndose tenido hasta aqui tan poca consideración con los pinales, siendo assi que son tan nesesarios para la tablasón de barcos y maderas de edificios, permitiéndose una absoluta libertad en el corte de los pinos, de lo que ha probenido una despoblación de grandes pedasos de terrenos, se debe prohibir absolutamente el que persona alguna pueda cortar en dichos pinales madera sin lizencia de la Junta y presencia del guarda, so pena de perder la madera. Y se le encargará estrechamente no permita el corte de pinos que no estén bien hechos con pretesto de sacar soleras y jubrones, pues las primeras se pueden haser de los gajos y retales, y los segundos de vigas aserradas, vajo las penas significadas para los que cortan sin lizencia en la montaña y Monte de Lentiscal.

9. ${ }^{\circ}$. Habiendo tomado tanta altura el valor de las //64rto maderas de tea adbitrariamente $y$ sin tener las tosas y vigas, jubrones y soleras una sierta medida de grueso y largo, como se obserba en otras probincias, combendria por punto de buen gobierno el que la ciudad fijase en esto algunas reglas por asunto de mucha importancia para las fábricas de edificios y buques.

10. ${ }^{\circ}$. Quando los leñadores no encuentren desechos de retales, gajos o árboles secos de que haser la leña, en este caso permitirán los guardas el corte de algunos árboles, aunque sean verdes, con tal de que sean de asebiño y de otros que estén desgajados, [h]endidos, retuertos, chamoros o chaparrados, de los quales no deba esperarse provecho para piezas de obra de tierra y marino; pero habrá de ser en el estrechísimo caso de no haberla seca en todas las montañas, absteniéndose en todo caso de tocar aquellos árboles que estubiesen vien guiados y derechos, sean viejos o nuevos.

11. . La misma prohibición de cortarse sin lizencia los pinos se deberá entender también para los sabinales y demás especies de árboles de //64vto monte que se crien en los del otro lado de las cumbres desta ysla, de que se está mirando haberse hecho una dolorosisima destrucción, de suerte que es de temer que llegue a una total en aquellas partes. 
12. . Para que la Junta pueda resolber con madurez lo que combenga en orden a los plantios, se podría pedir informe a los guardas de los tres diferentes montes, a fin de que espusiesen con claridad qué parajes están más despoblados, qué especies de árboles se reconocen, por qué medios mejor se aumentan, si de simiente o barbado, quáles por lo uno y quáles por lo otro, qué especies son más raras y que por lo mismo se nesesita recurrir a su replantación antes que enteramente se destruian, y en qué tiempo se advierte más sasonada la semilla, prebiniéndoseles desde luego que de los dichos árboles raros, en los que se comprehende el til, sabina, barbusano, jalla y hijo y palo blanco, no permitan su corte sin bastante nesesidad, por ser tan nesesarios para dibersas obras y usos de carpintería ensamblados //65rto, conforme se contiene en el nuebo plan de gobierno de montes en el párrafo $3 .^{\circ}$.

13. ${ }^{\circ}$. No habiendo llegado el caso de haberse hecho saber a los pueblos de la ysla lo dispositibo de la dicha nueva planta de gobierno, como se dispone en el párrafo 23 de ella, se podría y debería consultar al superior tribunal de la Real Audiencia, suplicándose se sirba prescribir el modo y forma de poner en ejecución la referida publicación. Para que no se alegue ignorancia y para que del mismo modo los referidos guardas se impongan en sus respectibas obligaciones, se les debería pasar una copia integra del dicho nuebo plan y de los párrafos que de este plan tuviere a bien aprobar dicho tribunal.

14. ${ }^{\circ}$. En punto de siembras, lo más fásil y combeniente parece ser por semillas recogidas a su debida sasón en los mismos montes. Y respecto a que el Escobón no ai dél mucho en la Montaña de Oramas y ninguno en el Lentiscal, se podría también sembrar esta semilla //65vto y castaña, por ser árboles muy prontos en adelantarse y de ex[c]elente leña el escobón, que se multiplica mucho por semilla, y el castaño ser lo nesesario para muchos usos, además de su fruto, que es tan apreciable, $Y$ en el Lentiscal se pueden haser los plantios de asebuche por estaca, que prende bien, y los lentiscos de Barbados y su vaga, y teniéndose en consideración la calidad deste clima combendría que las dichas siembras y replantos se hiciesen desde mediado diziembre hasta mediado febrero, conforme al capitulo 11 de la citada real cédula de montes, lo qual se podria ejecutar atendida la escases de propios por los mismos vecinos, poniendo cada uno su persona o un peón, pues que son interesados en la conzerbación de los montes, como se deduse del capitulo 9 hasta el 14 de dicha real ynstrucción, asistiendo a ello una persona inteligente que dirija los plantios conforme a la instrucción que se le comunicase por la Junta en dicha ocasión.

15. . Se deberia encargar a los guardas, como uno de los puntos más esenciales de la conser//66rtobación de los montes, la obserbancia rigurosa del párrafo primero del nuebo plan reducida a no permitir en la dicha montaña $y$ montes, assi en lo vedado como en lo no vedado, ganado cabrio ni serdo que no tenga arganel; $y$ en lo que no estubiere bedado para el corte habrá citios en que no deban entrar especie alguna de ganados por estar poblada de arbolitos nuebos y, por lo tanto, se les debería adbertir hagan guardar el acotamiento en semejantes citios, permitiéndose sin embargo sacar la [h]ierba arrancada pero sin rosar, vajo las penas establesidas al capitulo 21 de real cédula de montes. 
Y para que todo lo que acordare la Junta tenga el rigor correspondiente en razón de esta propuesta, pide el exponente se sirva consultarlo al superior tribunal de la Real Audiencia a fin de que se sirva aprobar o reprobar, como sea más de su agrado, dichas adiciones; y asimismo declarar si, en el caso de estar ocupados en asuntos del señor corregidor o ciudad o ausentes los escribanos de Ayuntamiento, podrá la Junta valerse de cualesquiera otro del número para celebrar sus actas y de qué modo habrá de gober//66vto narse para solicitar de Su Majestad la aprobación del nuevo plan aprobado, si lo ha de hacer la ciudad o esta Junta; y lo mismo para la aprobación del Consejo Supremo en orden a la asignación que del caudal de propios se les ha señalado a los guardas y sobreguarda, que es cuanto se le ofrece que decir en la materia.

Se acordó que, sacándose testimonio de la propuesta anterior, se pase en consulta a la Real Audiencia para que resuelva.

Certificación del escribano receptor de la Real Audiencia, D. Francisco Martínez, de pasar a la Junta razón de una denuncia del teniente de guarda mayor de la Montaña de Doramas de 23 de octubre. Se acordó se una al legajo que corresponde.

Memorial de Gregorio Hernández, vecino de Fontanales, solicitando licencia para cortar en la Montaña de Doramas una cumbrera y cuatro soleras para su casa. Se acordó conceder la licencia y pasarlo al corregidor para que expida la correspondiente.

\section{8}

1788/Noviembre/5. Canaria.

Junta con asistencia de D. Isidoro Romero, regidor perpetuo, y D. Andrés Cabrera, diputado del común.

Memorial de José Navarro, vecino de Canaria, solicitando licencia para cortar madera para una lancha, que consta de la memoria que presentó firmada por el maestre de ribera Miguel Farias. Se acordó conceder la licencia y se pase al corregidor para que la expida.

\section{9}

1788/Noviembre/8. Canaria.

Junta con asistencia de D. Isidoro Romero, regidor perpetuo, D. Andrés Cabrera, diputado del común, y D. José Gómez, síndico personero.

Presentación por D. Isidoro Romero del escrito y decreto de la Real Audiencia. En Canaria, 8 de Noviembre de 1788, Juan de Almeida, vecino de Guía y guarda mayor de la Montaña de Doramas nombrado por el Cabildo, dice que para cumplir con su cargo debe pasar casi diariamente a la referida montaña y registrar todos sus bosques espesuras hasta los parajes más remotos para evitar los continuos fraudes y como quiera que dicho empleo es odioso y lleba consigo la emulacion de todas las personas que se hallan conmescladas en semejantes exesos, y maiormente quando reconosen no poder ejecutarlos sin que esperimenten las penas establesidas, a causa del ningún disimulo que en mí encuentran por el notorio celo y cuidado con que me porto y procuro desempeñar 
dicho encargo, ha llegado el caso que algunos delinquentes quando me encuentran solo se resisten a entregarme la hacha $u$ otra qualquiera pieza de herramienta con que quebrantan la prohibición: por cuia razón, y para ebitar el posible contingente de esperimentar en mi persona alguna fatal desgracia a que estoy expuesto, me ha sido presiso llebar en mi compañia a un hombre pagándole dos reales plata diarios, además del presiso mantenimiento el tiempo ha que ejerzo dicho empleo, en el que no me es posible continuar con este gravamen y perjuicio a menos que por el citado Cavildo y Ayuntamiento se probea de un guarda menor que me acompañe a todas las gestiones que yo practicase en dicha montaña, con señalamiento de alguna renta o que se adelante alguna más cantidad a la mía para que pueda sufrir el pagamento de un hombre de mi satisfación para el referido fin [...]. Los señores mandaron que pase este memorial a la Junta.

Y la Junta acordó que, teniendo por precisa que haya dos guardas menores, le parece justa la pretensión, a quienes contempla se les puede dar una gratificación o ayuda de costa anual del fondo destinado para los replantos, que es el de 5 reales por cada pie de árbol que se corte, lo cual se consulte con la Audiencia para que, siendo de su aprobación, pueda proceder a la nominación de sujetos.

Memorial de D. José Rojo pidiendo licencia para extraer del Monte Lentiscal tierra a fin de reparar en su hacienda de la Vega los daños que la causó la lluvia del 3 del corriente. Se acordó que informen el sobreguarda de la Real Audiencia y teniente de guarda Agustín Velázquez de qué paraje se podrá extraer dicha tierra sin perjuicio notable del monte.

\section{0}

\section{8/Diciembre/10. Canaria.}

Junta con asistencia de D. Francisco de León y D. Isidoro Romero, regidores perpetuos, D. Nicolás Massieu y D. Andrés Cabrera, diputado del común.

Habiéndose entendido que los dos tenientes de guarda de la Montaña de Doramas no han puesto en entera ejecución de los capitulos primero al seis de la instrucción que se les comunicó especialmente sobre la entrada de ganados, se acordó se les haga saber cumplan al pie de la letra dichos capítulos, pues de lo contrario se tomará providencia y serán responsables.

Habiéndose tratado sobre el replanto de los montes de la isla a causa de ser este el tiempo oportuno para ellos, y prometiendo la abundancia de lluvias que experimentan, se acordó suplicar a la Real Audiencia se sirva mandar que los alcaldes de los pueblos comarcanos a los parajes que necesiten de replanto en la Montaña y Monte Lentiscal faciliten a los guardas el número de personas de sus respectivos vecindarios que por dichos guardas se les pidan en los dias que estos señalaren para hacer dichos replantos.

Habiéndose tenido presente el deseo de la Real Sociedad de ayudar al replanto de los montes, según el oficio que pasó a la ciudad en 12 de febrero de este año, se acordó se pase oficio por el señor D. Francisco de León manifestando la oportunidad que ofrece la ocasión y tiempo para dichos replantos, y que la Junta tiene acordado en acta de este dia suplicar a la Real Audiencia 
para que los alcaldes de los pueblos comarcanos a la Montaña y Monte Lentiscal faciliten el número de personas que se les pidan por los guardas para hacer los replantos.

\section{1}

1788/Diciembre/13. Canaria.

Junta con asistencia de D. Francisco de León y D. Isidoro Romero y Zevallos, regidores perpetuos, D. Nicolás Massieu, diputado del común.

Habiéndose enterado la Junta que no se ha puesto en noticia a todos los pueblos inmediatos a la Montaña de Doramas y pinar los medios y reglas mandados observar por la Real Audiencia para su conservación y aumento, se acordó que el presente escribano acabe de dar curso a dichas publicaciones en los lugares donde no se haya hecho.

Presentación por D. Francisco de León de un testimonio de la Real Audiencia por la consulta de la Junta sobre los medios para el replanto en el Lentiscal y Montaña de Doramas, que es el siguiente: En Canaria, en 11 de diciembre de 1788, habiendo visto el acuerdo de 10 de diciembre de la Junta de Montes sobre el replanto de estos, dijeron que, por ahora y sin perjuicio de los salarios que se deben pagar a los que asistan al plantio para lo que pase a la vista del señor fiscal de Su Majestad, se ejecute como lo ha acordado la Junta, valiéndose para ello de los medios que tenga por oportunos.

Y en su vista se acordó que por medio de D. Francisco de León se ponga en noticia del señor corregidor los medios ocurridos a la Junta a fin de que se verifiquen sin demora dichos plantios y que dé las correspondientes órdenes a los alcaldes para que estos cooperen por su parte en auxiliar a los guardas de los montes.

Asimismo, se acordó que por el presente escribano se escriban cartas a los dos guardas de la Montaña de Doramas y el pinar para que el día 22 del corriente se hallen en esta ciudad a fin de que informen a la Junta de las novedades que hayan ocurrido en el tiempo que tienen a su cargo dicho empleo conforme al reglamento, e instruirles del modo y forma que deban practicar los replantos y demás que se ofrece.

D. Francisco de León presentó la carta a la Sociedad y se aprobó.

\section{2}

\section{8/Diciembre/15. Canaria.}

Junta con asistencia de D. Francisco de León y D. Isidoro Romero, regidores perpetuos, D. Andrés Cabrera, diputado del común, y D. José Gómez, síndico personero.

Se vio la presentación que hizo a la Real Audiencia el sobreguarda de la Montaña de Doramas nombrado por ese tribunal, D. Juan Antonio Domínguez, el 13 de este mes, y el decreto a ella proveído por dicho tribunal. Y se acordó se le entregue a dicho sobreguarda igual instrucción a la que se dio a los guardas nombrados por la Junta, ya que en el escrito que presentó a la Audiencia viene a pedir que se le entregue la instrucción para el gobierno y métodos de los guardas de los montes. 
13

1788/Diciembre/16. Canaria.

Junta con asistencia de D. Francisco de León y D. Isidoro Romero, regidores perpetuos, D. Andrés Cabrera, diputado del común, y D. José Gómez, síndico personero.

D. Francisco de León da parte de cómo, habiendo pasado a casa del corregidor a comunicarle el encargo que se le hizo el 13 de diciembre para que facilitase los medios de los replantos y la publicación en los pueblos, el corregidor dijo que para obrar con la formalidad correspondiente se diese dicho paso por escrito, y se le pase testimonio de lo acordado en la materia. Y la Junta acordó que se saque testimonio del auto de la Real Audiencia y de lo acordado en su consecuencia y se pase al corregidor.

\section{4}

\section{8/Diciembre/22. Canaria.}

Junta con asistencia de D. Francisco de León y D. Isidoro Romero, regidores perpetuos, D. Nicolás Massieu, diputado del común, y D. José Gómez, síndico personero.

Se acordó que por el presente escribano se saque testimonio íntegro del reglamento de montes y se pase al corregidor para que se sirva mandar por veredas a los respectivos alcaldes lo publiquen en los pueblos de su jurisdicción, y que sea íntegro sin limitación de ningún capítulo.

Habiéndose tratado sobre los límites de la Montaña, a consecuencia de haber dado parte uno de los tenientes de guarda a la Junta que del amojonamiento y deslinde hecho por el escribano D. Carlos Vázquez en el mes próximo pasado de mandato de la Real Audiencia resultaba notable perjuicio público y mucho beneficio a los detentadores, de todo lo cual tenía dado cuenta al señor corregidor, se acordó que por el presente escribano, sacando testimonio de este acuerdo, se ponga en noticia de la Real Audiencia para que dicho superior tribunal tome las providencias que tenga por conveniente; e igualmente el que con motivo de hallarse varios deslindes hechos en diversos tiempos ignora la Junta a cuál deberá estar para con arreglo a él procurar su reintegro a beneficio del público.

D. Francisco de León manifestó la respuesta dada a nombre de la Real Sociedad en 17 del corriente y firmada de su vicedirector, D. Luis de la Encina, al oficio que le pasó por acuerdo de esta junta de 13 del mismo. Se acordó se den las gracias a dicho cuerpo.

Habiendo comparecido personalmente los dos guardas nombrados por ella de la Montaña de Doramas a consecuencia de lo acordado en 13 del corriente, se les previno el método que deberán observar en los replantos de dicha montaña y que de todo lo que ocurriere dieren cuenta a la Junta, como también lo ejecutasen semanalmente de lo que en dichos replantos fueren adelantando.

\section{5}

1789/Enero/ 12. Canaria. 
Junta con asistencia de D. Francisco de León y D. Isidoro Romero, regidores perpetuos, D. Andrés Cabrera, diputado del común, y D. Juan Reyes, síndico personero.

Se vio un memorial de Ildefonso Cayetano de Santa Ana, en que solicita licencia para doce docenas de galápagos, diez de toletes y cuatro cepos de ancla, para el uso de sus barcos en la pesca de la costa de África. Se acordó se concede y se pase al corregidor para que la expida.

Memorial de D. Domingo Galdós, receptor del Santo Oficio, con memoria jurada del carpintero Esteban Pastrana, en el que solicita para las fábricas del Santo Oficio ochenta tijerones de a seis varas y media de largo, veinte vigas de a siete varas y media de largo y palmo y torno en cuadra, cuarenta tosas de a cuatro varas y veinte de a cuatro varas y medio. Y se acordó concederla.

Memorial de Cristóbal Morales, beneficiado de la parroquial de Telde, en que para la construcción de una casa de su habitación pide licencia con memoria jurada del oficial para sacar del Pinar veinte tosas, cuarenta jubrones, cien tijeras y doce vigas. Se le concede.

D. Isidoro Romero presenta dos cartas del teniente de guarda de la Montaña Francisco Dominguez Falcón en que representa, entre otras cosas, lo urgente e indispensable que es la publicación de reglamento de montes para su entero cumplimiento, y que los alcaldes presten el auxilio necesario para el desempeño de sus funciones.

Hágase saber a los tenientes de guardas y sobreguardas de la Montaña de Doramas se guarde y cumpla el acuerdo de esta Junta que prohíbe el corte de follados para el uso de hogares, pues se reserva para la arquería de pipas, canastas y demás utensilios de labranza.

Memorial de D. Miguel de la Nuez, D. Vicente Romero, Felipe Monzón, D. Antonio, D. Bernabé de Vega, José Rodríguez, Salvador de la Coba, José Alonso y demás vecinos, labradores y criadores, vecinos de la Vega, para entrar en el Monte Lentiscal y segar la hierba para alimentar a los animales por la falta de ella en el resto. Se acordó que, teniendo noticia de la escasez de hierba en las medianías y cumbres de la isla, y además haber informado el guarda y sobreguarda de que hay sitios donde se puede sacar hierba sin tener a causar daño a los acebuches, se pueda sacar hierba de los parajes que señalaren los guardas.

\section{6}

\section{9/Enero/26. Canaria.}

Junta con asistencia de D. Francisco de León y D. Isidoro Romero, regidores perpetuos, D. Andrés Cabrera, diputado del común, y D. Juan Reyes, síndico personero.

//81rto El señor don Francisco de León expuso que el día veinte del presente mes le dijo Agustín Velázquez, guarda del Monte Lentiscal que, a consequencia de lo acordado por la Junta en rasón de la yerba de dicho Monte, pasó a el día quince del propio y señaló del Roque de los Hoyos abajo del replanto de plaza pendida abajo y de los toscones del Tablero abajo para que en estos sitios únicamente se arrancase la yerba sacándola de dentro del Monte y dándola de 
comer a los animales fuera dél, prohibiendo el que la segasen, porque con malicia o sin ella cortarian los tiernos arbolitos que podian estar dentro de ella. Lo que hiso saver a quantos encontró dentro y fuera de dicho Monte, encargando a cada //81vto uno de ellos lo dijeren a los que vieren.

Pero haviendo buelto al referido Monte el dia dies y nueve vio a José Diaz, vecino de Tafira, y a otros que no conoció (ni quisieron dar sus nombres), segando con hoces la yerba dentro de la Hoya de Plaza Perdida (o Lentisquera), en donde mismo estuvieron muchos hombres dias pasados haciendo replantos de cuenta de la Sociedad bajo la dirección del capitán don José Arboniez, y vio arrancada una de las estacas de olivos que se plantaron, y pisoteado de hombres y de animales todo el sitio replantado. Y haviéndoles reprenhendido por el mal que havian hecho y que necesariamente hasian (aún sin querer) se resistieron a salir de dentro de dicho sitio replantado, hasta que //82rto les amenasó, advirtiéndoles nuevamente de donde debian arrancar la yerba sin usar de hoz con pretexto alguno.

Que de este sitio pasó dicho Velázquez a los demás del referido Monte y halló a muchas personas, $y$ dentro de ellos segando la yerba y muchos animales, los que dejó embargados; y a todos reprehendió y previno lo mismo que a los que halló en la Hoya de Plaza Perdida o Lentisquera, pero el moso de don Miguel Noria se le resistió con voces descompuestas, haviéndolo hecho también con el garrote el dia cinco del corriente $y$ que en vista de estos $y$ del haver dicho el expresado Velázquez que pasaba aquella noche a rondar el Monte, para lo qual habia dejado prevenido a Antonio Rodriguez, sobreguarda nombrado por la Real Audiencia, para que lo esperara en la Hoya de Mondalón como //82vto a hora de las nueve de la noche a fin de rondar ambos, pero que le era preciso llebar auxilio. Le previno estuviese con el señor corregidor, le contase quanto deja expuesto y demás que acaso le puede haver ocurrido y olbidarse ahora $y$ le pidiese el auxilio que necesitara. Y que en la noche del dia veinte y dos del propio mes le dio quenta el referido Velázquez de que, haviéndole dado el señor corregidor el auxilio de dos alguaciles y llevado además otro hombre consigo, pasó al Monte Lentiscal la noche del dia veinte a la hora y sitio concertado con el sobreguarda de la Real Audiencia, al que halló acompañado de otros hombres para su seguridad, y aunque rondaron el resto de la noche no hallaron cosa que hiciere daño al //83rto Monte. Pero al dia siguiente, que fue el veinte y uno, advirtieron que havia muchos hombres segando la yerba con hoces en el monte prohibido y sueltos los animales, los quales remitió a esta ciudad, como también algunas reses bacunas, a cuyos pastores habia prevenido dias antes que sin embargo de tenerlas atadas las alejasen, reprehendiendo a todos por haverlos cogido segando la yerba, quando ninguno ignoraba que estaba prohibido el entrar con hoces en el Monte por el daño que voluntaria o involuntariamente era indispensable se hiciese con ellas a los nuevos arbolitos que estaban nasidos entre la yerba, como todo constaba más largamente de la declaración que havía dado ante el señor corregidor en este dia.

//83vto A lo que añadió que si no se havia un riguroso castigo ni el Monte se podía guardar ni él se atrevía a bolber a él en calidad de guarda y mucho menos solo. Todo lo que hacia presente a la Junta dicho señor para que acordase lo que le pareciera más combeniente a fin de evitar los ex[c]esos y desórdenes que 
han resultado de la indulgencia que tuvo para con los vecinos del lugar de la Vega, teniéndose presente que la yerba ni seca ni verde perjudica a los árboles del enunciado Monte y que importa más criar monte que ganado en la actual constitución del país.

La Junta acordó que quería oír al señor sindico personero, quien dijo //84rto que por casualidad se halló una noche en la sala del despacho del señor corregidor a tiempo que los cavalleros don José Arboniez y don Manuel del Río estaban evacuando una diputación con el señor corregidor a la Real Sociedad en que le participaba los daños que se reconocían en el Monte Lentiscal con el modo en que se sacaba la yerba de él, solicitando el remedio para no experimentar la absoluta destrucción de los plantios y arbolitos que naturalmente se reproducen, supuesta la abundante hibernada que hemos tenido, con cuya inteligencia hiso ánimo desde luego de exponer en primera Junta, como lo hace en esta, que atendido el abuso con que se han dirigido los vecinos de los luga//84vtores inmediatos al monte Lentiscal en la saca de yerbas que se les toleró por pura equidad y atención a sus clamores, se acuerde por la Junta con la mayor prontitud la cierra absoluta de dicho monte para la saca de yerba y qualquier otro uso que se pueda hacer en él, solicitando dónde y ante quien contenga que sobre las penas establecidas a los contraventores en las reglas dadas para la cierra de dicho Monte se impongan otras que sean las mayores y más fuertes capaces de contener un desorden como el que se ha advertido, pues el personero opina, atendida la necesidad de la conserbación de esta alhaja pública, ser menos dañoso al//85rto común que perescan esas reses que havian de conserbarse con la yerba del Monte, que no que a este se le cause el más leve atraso en las actuales circunstancias en que se trata de su restablecimiento, y para lo qual sabe el personero se han hecho con zelo patriótico diversos plantios aprovechando la hermosa estación del hi[n]bierno con que la divina providencia nos ha favorecido protestando como protesta a nombre del público los daños y perjuicios que se le sigan en el caso de la más leve condescendencia a los clamores de los vecinos que en mucha parte tiene el personero por infundados, supuesto que, cuando no en las cumbres, en las medianias y partes de estas se hallan pastos abundantes.

La Junta acordó se prohíba el sacar yerba del Monte de todos modos bajo las penas establecidas para los que sacasen leña y estiércol.

\section{7}

\section{9/Febrero/4. Canaria.}

Junta con asistencia de D. Francisco de León y D. Isidoro Romero, regidores perpetuos, y D. Andrés Cabrera, diputado del común.

Memorial del teniente coronel D. Pedro Huésterlin en que bajo su palabra de honor solicita para la fábrica de una casa en una de sus propiedades cuarenta tijeras aserradas y tres vigas del pinar.

Memorial del presbítero D. Francisco Perera, con memoria jurada de Esteban Pastrana, de necesitar cincuenta jubrones de a siete varas y media, veinte tosas comunes y treinta soleras para componer las casas de su hacienda de las Goteras. 
Memorial del coronel D. José de la Rocha pidiendo licencia para ciento treinta y dos tosas, veintiséis vigas, cincuenta y seis jubrones, ochenta y cuatro tijeras y treinta soleras de arrastrar para el hospicio de esta ciudad y hospital de Telde con memoria jurada de Lorenzo de Niz, carpintero.

Memorial de D. Domingo Galdós en que pide licencia para la fábrica de un barco de 50 palmos de quilla con memoria jurada.

Más una representación de D. Andrés Cabrera pidiendo para la composición de sus casas veinte jubrones, ocho tosas y treinta y cuatro tijerones. Se acordó ponerlas en el hueco correspondiente y se le concede licencia a cada uno.

El escribano presenta auto de la Real Audiencia, con fecha de 28 de enero de 1789, en el que, visto el acuerdo de la Junta de Montes de 26 de enero prohibiendo la saca de hierba del Lentiscal bajo penas establecidas para los que saquen leña o estiércol, confirma la prohibición, aunque no ha lugar la agravación de mayores penas sino exigiendo las impuestas con todo rigor sin indulgencia.

Memorial del doctor D. Luis Manrrique, canónigo de la catedral, solicitando licencia para cortar de la Montaña de Doramas para la fábrica de una casa en el lugar de Moya y pago de Pavón, cuarenta tijeras, una cumbrera, veinticuatro jubrones, seis tosas, un pie derecho y las varas para envarar la casa, que consta de la memoria jurada que acompañada.

Memorial de D. Isidoro Romero pidiendo licencia para cortar y sacar del Pinar diez tosas, veinte vigas sencillas, sesenta soleras y veinte jubrones cuadrados para la fábrica de una casa. Se acuerda conceder ambas licencias.

\section{8}

\section{9/Febrero/25. Canaria.}

Junta con asistencia de D. Francisco de León y D. Isidoro Romero, regidores perpetuos, y D. Andrés Cabrera, diputado del común.

Representación de D. Antonio Tobar y Falcón, subteniente de milicias provinciales, vecino de Tejeda y teniente de guarda en el Pinar, diciendo que la renta que se le tiene señalada es para el cuidado de los Pinares, y que de ellos no se haga aquel abandono que diariamente padecian, que los tiene andados $\mathrm{y}$ registrados, $\mathrm{y}$ ha hallado que los pinitos pequeños los asolan los ganados, que son ovejas que llaman del pinar. Que en cuanto a la división que se deba hacer precisa, el que se haga con brevedad por medio de peritos inteligenciados a fin de que en lo que quede totalmente vedado se verifique el aumento, para lo cual necesita el auxilio de los alcaldes, sobre todo en este asunto porque jamás se ha verificado haver guardas en pinales, y a todos causa novedad su custodia, queriéndolo tener relajado como siempre. Y solicita que determine la Junta los derechos que deba percibir por los trabajos de asistencia de los cortes de madera en las licencias que se despachan por ser el trabajo más recio y le siguen los costos de bestia y asistencia a veces tres dias y otras ocho, según el paraje donde se pretenda el corte. 
Otra carta del mismo de 15 del corriente comunicando haber dado cumplimiento y que se la ha auxiliado en lo que se le ha ofrecido por el alcalde de Tejeda.

A la vista, se acordó comunicarle, y a los demás guardas, que la Junta no puede acordar el pago de los salarios que les están señalados por ahora hasta que venga orden del Consejo. Que en cuanto a la división, la ejecute el mismo guarda valiéndose de las noticias, medios y arbitrios que le parezcan más oportunos para verificarla en los términos más útiles para la conservación y aumento. Y que por cada dia que asista al corte de madera que se haga, le pague el interesado en ella 6 reales de vellón corriente cada día.

Se vio un informe de Juan de Almeida, teniente de sobreguarda mayor de la Montaña de Doramas, a la que se adhirió verbalmente D. Francisco Domínguez Naranjo, señalando la zona más conveniente para el corte de leña. Y señala que el más a propósito es en el paraje que llaman el Peñón comprehendido por la parte de arriba desde las cuevas del Gallego que están en el barranco que llaman del Laurel siguiendo el lomito arriba de dichas cuevas a dar al Lomo del Peñón, bajando por la sorruedilla a finalizar al barranco que viene de las madres del pinal barranco abajo saliendo por los Lanses a coger las cordilleras, cordillera arriba a dar al primer lindero de las cuebas del Gallego, sin tocar en los árboles de dichas cordilleras por hallarse desepados de los carboneros. Se acordó se ejecute el corte dentro de los limites señalados en su informe.

Habiendo entendido que aún no ha salido el ganado de la Montaña de Doramas, a pesar de lo prevenido en la instrucción, y sabiendo que el señor corregidor libró un despacho circular por medio del presente escribano para que todos y cada uno de los lugares de la isla diese a dichos guardas el auxilio que le pidiese, se haga saber a estos que de no hacer salir a los ganados de la Montaña se procederá contra ellos en los términos que se indica en la instrucción. Y se les hace saber que ha sido muy del desagrado de la Junta el que aquellos a quien se le ha concedido licencia para cortar madera se le hayan hecho exigir 15 reales de plata en cada día en que se verifica el corte, repartiéndoselos entre sí a 5 reales cada uno, como si en la realidad asistiesen todos los guardas cada día.

Vista las ventajas de la poda que se hizo en los meses de diciembre y enero en los árboles del Monte Lentiscal, se manda se haga lo mismo a los demás que la necesiten, ya por hallarse secas las ramas ya por la maleza que se ve en los pequeños.

Considerando la Junta que ni su establecimiento ni el reglamento hecho para el gobierno económico de los montes de la isla ni las dotaciones de los guardas de ellos se hallan aprobados por el Supremo Consejo, aunque lo están por la ciudad y confirmados por la Real Audiencia, se acordó se represente a Su Majestad o su Supremo Consejo se digne aprobar el establecimiento de la Junta de Montes, el reglamento hecho para su gobierno económico con las adiciones que hizo la ciudad y Junta, la dotación de los guardas. 
Memorial de D. Sancho Figueroa, ayudante mayor del regimiento de Telde, solicitando licencia para cortar y sacar del pinar trescientas treinta y tres piezas de madera para concluir una fábrica de casas en los Llanos de Telde. Se acuerda se le conceda.

\section{9}

\section{9/Marzo/10. Canaria.}

Junta con asistencia de D. Isidoro Romero, regidor perpetuo, y D. Andrés Cabrera, diputado del común.

Auto de la Real Audiencia de 2 de marzo de 1789 en el que, visto el recurso hecho por D. José Suárez de Aguilar, alcalde de Guía, por su exposición de 20 de febrero sobre el deplorable estado en que se halla la Montaña de Doramas después de haberse nombrado teniente de guarda mayor de ella a Juan de Almeida y lo demás que en ella se refiere, pase dicha representación a la Junta de Montes para que acuerde lo que hallare más conveniente. Y habiéndose tratado sobre ello y en vista de las varias noticias que sobre el mismo asunto ha tenido la Junta, para resolver sobre todo se acordó se llame a Junta a dicho efecto el jueves 12 a las 10 de la mañana.

El receptor de la Real Audiencia presentó otro auto de la Real Audiencia a consecuencia del recurso presentado en ese tribunal por Ildefonso de Santa Ana, José Flores, Andrés Negrín y demás dueños de barcos de la costa de pesquería de esta isla, en la que piden que por el escribano se le dé certificación del Libro de Acuerdos del Ayuntamiento en el que consta haberse mandado se diese a los suyos sin derechos las competentes licencias para el corte de toletes, galápagos y latas, utensilios necesarios para el surtimiento de los barcos. Y con dicha certificación la Audiencia manda, por auto de 18 de febrero de 1789, que se remita a la Junta testimonio de lo acordado por la ciudad en 23 de marzo de 1787 a fin de que arreglen sus providencias para lo sucesivo, y que el escribano y guardas devuelvan a esta parte los derechos que le hayan exigido. Y se acordó obedecer y se guarde y cumpla como en él se previene, haciéndose saber su contenido a los tenientes de guarda mayor de la Montaña de Doramas.

Se hizo saber otro auto de la Real Audiencia por el que se remita a esta Junta varias denuncias dadas en aquel tribunal por D. Juan Antonio Domínguez, teniente de sobreguarda mayor puesto por el tribunal. Se acordó que de dichas denuncias se saque copia y remita por el presente escribano al corregidor para que le dé su curso.

Se presentó una petición de varios vecinos de la Vega, Teror y San Lorenzo pretendiendo se les dé licencia para aprovechar con sus animales la hierba del monte, y presentan para ello un auto de la Real Audiencia de 28 de enero de 1789 en el que manda que las partes acudan a la Junta de Montes y que esta resuelva lo que tenga por conveniente. Y se acordó se dé vista al teniente de guarda de dicho monte nombrado por esta Junta y al sobreguarda de la Real Audiencia para que expongan lo que se les ofrezca en beneficio de la causa pública, y luego pase al sindico para que informe y se dé cuenta luego a la Junta para resolver. 


\section{0}

\section{9/Marzo/ 12. Canaria.}

Junta con asistencia de D. Isidoro Romero, regidor perpetuo, y D. Andrés Cabrera, diputado del común.

Habiéndose tratado sobre una representación del alcalde de Guía reducida a la mala versación del teniente de guardamayor de la Montaña de Doramas Juan Almeida, y el auto de la Real Audiencia de 2 del corriente que se encuentra en el acta anterior, se acordó que los diputados y síndico personero del citado pueblo de Guía informen con vistas de dicha representación, para lo cual el escribano sacará testimonio de ella con carta de orden de esta Junta.

\section{1}

\section{9/Marzo/26. Canaria.}

Junta con asistencia de D. Isidoro Romero, regidor perpetuo, y D. Andrés Cabrera, diputado del común.

Presentación por parte de Agustín Velázquez y Antonio Rodríguez, teniente de guardamayor y sobreguarda del Monte Lentiscal, del informe que en junta de 10 del corriente mes se les mandó dar en razón de la solicitud de vecinos de la Vega para que se les permitiese sacar hierba de dicho monte y una representación del sindico personero, que son las siguientes:

En cuanto al informe, los guardas dicen que en 1771 y $1776 / / 101$ rto estubo dicho monte serrado en la misma conformidad que aora, los ganados de labor y vestias de servizios aprobechavan sus pastos y los árboles se extendieron $y$ multiplicaron en aquel término prodigiosamente; pero en aquel entonces parece que los aprovechadores del yerbaje miraban con más apropio la extención del Monte. Ellos tenian sus animales amarrados en las orillas, gruesos, y manifestando complasencia en tomarse el trabajo de segar la yerva, pero en esta última época en que se les dio permiso en ciertos y determinados sitios para aprobecharla se ha observado mucho desorden, pues todos protestan el que observar el no dañar, y se experimenta que al ir a sacar el pasto sueltan los animales $y$ estos lo pisotean y estropean, y después, aunque aquel pasto que se queda solamente desflorado se quiera dar a otros animales, ya no lo aprovechan estando casi sensillo fuera de alli. Bajo los árboles //101vto grandes se encuentran renuevos tiernos que maltratan y que al siguiente año, trasplantándose a los despoblados, venian sin dificultad a ser árboles que causasen frondosedad = El socorro de las yuntas de labor y bestias de servicio, de que dimana muchas virtudes, es de atención sin pres/c]indir de lo antezedente. Se puede promover vajo las qualidades siguientes, según nuestro conocimiento y experiencia:

Primera: Que solo en las orillas del monte propiamente tales se puedan tener animales con la seguridad de que no sean capases de soltarse=

Segunda: Que todos los que amarrasen por dichas orillas propiamente tales y como en lo pasado estubo queden responsables mancomunadamente en sus respectivos parajes racionalmente tomados a suplir la pena de qualesq[u]iera defraude que en sus inmediaciones se advierta $=/ / 102$ rto. 
Tersera: Que en la misma conformidad no se siegue yerva en donde se han hecho plantios, porque estos pereserán al impulso de la $\mathrm{Jos}^{10}$ o del arranque como confundidos con ella, ni tampoco en los presisos sircuitos donde ay renuevos de asebuches que a la buelta de un año ya son árboles seguros, transplantándolos o beneficiándolos, siendo de cuenta de los inmediatos pastorantes qualesquiera desfraude que se note [...].//102vto.

Canaria, marzo veinte de mil setecientos ochenta y nueve años. Por las partes, Antonio Thomás Manzano y Salas.

En cuanto a la presentación del síndico personero Juan Reyes Cabrera, dice que tiene visto tanto la presentación de los vecinos como el informe evacuado por el teniente de guarda y sobreguarda de la Real Audiencia, y es de dictamen el personero se deniegue dicha pretensión, pues reprodusido el monte tendrán permanente los ganados el abrigo que [h]oy solicitan para no disfrutarlo más que una bes, porque con olvido el monte se a acava la esperanza de que en lo venidero sirba para los objetos a que conspira su conserbación, y asi contradise en toda forma dicha pretención.

Se acordó se pueda sacar a mano la hierba de dicho monte con tal, y no de otra manera, que se constituyan antes en debida forma responsables a la guarda y perjuicios que puedan sobrevenir al monte nuevo y replantos nuevamente hechos ocho vecinos de la Vega a satisfacción de esta Junta, quienes se habrán de ceñir precisamente para la saca de dicha hierba con los demás vecinos que necesiten aprovecharla a los sitios que señale el teniente de guarda y el sobreguarda, durando dicho permiso de extraer dicha hierba hasta el 15 de abril, prohibiéndose la entrada de animal alguno.

Se presentó memorial jurado de Antonio Quintana Jardín, vecino de la ciudad, solicitando permiso para sacar del pinar cuarenta tosas, treinta y seis vigas y sesenta jubrones para una casa que va a hacer, de acuerdo a la regulación jurada del carpintero Lorenzo Déniz. Se acordó conceder la licencia.

Se vio otro memorial de Ildefonso de Santa Ana, vecino de esta ciudad, solicitando permiso para sacar y cortar del pinar, según la memoria del maestre calafate, la madera necesaria para carenar el barco San Judas. Se acordó conceder la licencia.

El sobreguarda de la Montaña de Doramas puesto por la Real Audiencia, D. Juan Antonio Domínguez, exhibió la instrucción que se le había dado para su gobierno, y se halló que faltaba la demarcación de la parte de montaña que debe estar abierta para sacar leña y demás necesario para el uso de los vecinos. Se acordó se saque testimonio de la demarcación última que se hizo por el informe que dio el teniente de guarda José Almeida, que está en la Junta de 25 de febrero pasado.

\section{2}

1789/Marzo/30. Canaria.

Junta con asistencia de D. Isidoro Romero, regidor perpetuo, y D. Andrés Cabrera, diputado del común.

$10 \mathrm{Hoz}$. 
Se vio un memorial presentado por D. José de Lugo y Cabrejas, teniente capitán de milicias, para sacar del pinar, de la parte del sur, cuarenta y dos vigas, veinticuatro tosas y ciento cuarenta jubrones de madera para la fábrica de una casa, según la lista del carpintero Ramón Jiménez. Se acordó conceder la licencia.

Se vio un memorial de D. Agustín Márquez Romero, vecino de la ciudad, y castellano de la fortaleza San Fernando, señalando que pretendiendo licencia para cortar madera del pinar para construir una casa y concedida por esta Junta, ocurre la novedad de que el guarda del pinar se opone, además de pedir doce pesos por dicho corte. Por ello pide que se mande a dicho guarda admita todas las personas que en el día puedan hacer con toda brevedad el corte, estando pronto a satisfacerle el diario que se le tiene señalado por semejante asistencia, pues parece que no lleva otra mira que el dilatar dias y tomar más de lo legítimo. Se acordó se haga saber a dicho guarda no impida que la persona que tenga licencia lleve todos los fragueros que necesitare para el más breve despacho del corte de la madera, con tal que puedan hacerlo a su vista, no llevando más derechos que los tres de plata que están acordados por día.

\section{3}

\section{9/Abril/1. Canaria.}

Junta con asistencia de D. Isidoro Romero, regidor perpetuo, y D. Andrés Cabrera, diputado del común, y D. Juan Reyes Cabrera, síndico personero.

Se da cuenta de un auto de la Real Audiencia de 28 de marzo de 1789 sobre el expediente promovido a instancia de diferentes vecinos labradores de esta ciudad, la Vega y otros lugares para que se les conceda licencia para la entrada en el Monte Lentiscal para sacar hierba y acudir al pasto, y que se trajo en apelación por el síndico personero del acuerdo celebrado por la Junta de Montes en 26 del corriente. por el cual les concedió a dichos labradores la extracción de dicho hierbaje. Y el auto revoca el citado acuerdo y no se conceda licencia alguna para la entrada en el Monte Lentiscal, y que la Junta reapruebe por ahora las penas conminado con las más rigurosas a los contraventores, consultando su acuerdo antes de ponerlo en ejecución con este tribunal. Se acordó se llame a junta en el que se tenga presente la ordenanza de 1748.

\section{4}

\section{9/Abril/2. Canaria.}

Junta con asistencia de D. Isidoro Romero, regidor perpetuo, y D. Andrés Cabrera, diputado del común, y D. Juan Reyes Cabrera, síndico personero.

Habiéndose visto y tratado sobre el auto de la Real Audiencia extendido en la Junta antecedente y tenida presente la real ordenanza de montes de 1748 $\mathrm{y}$ lo que dispone contra los que introducen ganados y hacen cortes en los parajes vedados, se acordó se haga presente a la superioridad que la Junta es de parecer que la pena que se imponga a los que se introducen en el Monte Lentiscal y en cualquier otro vedado a sacar hierba o leña o pastar animales sea la que dispone el capitulo 17 de dicha real cédula de montes contra los que cortaren árboles o introducen ganados en los parajes vedados; es decir, 
mil maravedíes de pena por la primera, el doble a la segunda y veinticinco ducados y cuatro campañas por la tercera, añadiendo los motivos por los que la Junta aceptó dar la licencia para que pudiesen cortar hierba.

Habiéndose visto el informe que hace Antonio Rodríguez y Agustín Velázquez, teniente de guarda y sobreguarda, en razón de la pretensión de D. José Rojo de Castro, que solicita permiso para sacar tierra del Monte Lentiscal para terraplenar algunos pedazos derruidos del terreno de la hacienda que tiene en Satautejo, en la Vega, acordó que para resolver quería oír antes al síndico personero, quien dijo que, teniendo en cuenta las circunstancias actuales en que se está tratando del fomento y reparación de dicho monte, le parece muy perjudicial la pretensión, en cuya virtud se opone. Y habiéndose tratado, el señor D. Isidoro Romero es del mismo dictamen que el síndico. mientras que D. Andrés Cabrera es favorable a que se le dé la licencia por lo que, en vista de la discordia, se acordó pase a la Real Audiencia para que resuelva, se saque testimonio y ponga a continuación de esta Junta la real ordenanza de montes de 1748 a fin de tenerla presente cuando fuere necesaria.

A continuación se transcribe la real ordenanza de montes de 12 de diciembre de 1748 .

\section{5}

\section{9/Abril/23. Canaria.}

Junta con asistencia de D. Isidoro Romero, regidor perpetuo, y D. Andrés Cabrera, diputado del común, y D. Juan Reyes Cabrera, síndico personero.

Exposición del síndico personero sobre que la Junta se creó para tratar y resolver los asuntos tocantes a la conservación y fomento de los montes con la mayor facilidad y prontitud que exija la importancia de la materia sin sufrir los retrasos de tratarse en los cabildos, pero que la actividad de los capitulares sobre los temas relacionados con montes tiene una gran morosidad, pues desde el 22 de diciembre pasado acordaron de consultar con la Real Audiencia lo representado por el sobreguarda de la Montaña de Doramas en razón de los perjuicios advertidos en el deslinde que se practicó en presencia del escribano del Cabildo D. Carlos Vázquez, en el que se damnificó bastante a dicha montaña y benefició a los detentadores de sus terrenos. Y siendo esta una materia que demuestra la necesidad de su pronta averiguación por medio de un nuevo reconocimiento aún no se ha pasado dicha consulta, habiendo el personero entendido en el tiempo de su oficio la certeza de dichos perjuicios, pero ignora el resorte que haya movido tal retraso, sobre lo cual protesta primera, segunda y tercera vez. Además, señala que en veintiún días desde que se tomó la decisión de remitir la discordia a la Real Audiencia no ha tenido efecto la consulta mandada siguiendo las personas en el monte, los cuales reclama y protesta el personero y pide a la Junta acuerde lo que tenga por conveniente. Se acuerda hacer saber al escribano la exposición del síndico personero y concluya la que se acordó en 2 del corriente.

D. Isidoro Romero manifiesta la noticia que le pasó el teniente de guardia Francisco Domínguez de las denuncias que ha dado al corregidor desde 30 de octubre hasta el presente, especificando que son catorce denuncias. Se 
acuerda que los escribanos de Cabildo informen a primera junta del curso que hayan tenido las denuncias y su estado.

Memorial de D. José León, presbitero, vecino de Agüimes, pretendiendo sacar madera del pinar para la fábrica de una casa con la nómina jurada del oficial.

Y otro memorial de D. José Rojo pidiendo licencia para sacar del pinar la madera que consta de la memoria jurada del oficial para la composición del barco San Antonio Abad. Se acordó conceder ambas licencias.

Y otro memorial del teniente de guarda mayor D. Francisco Domínguez pidiendo se le satisfaga su media renta vencida en los seis meses que tiene servido y los derechos de cortes a que ha asistido y los de las denuncias que ha dado. Se acordó que en atención a tener consultado a la Real Audiencia por junta de 31 de octubre pasado varios puntos relativos al mejor gobierno de la misma, entre ellos la paga de los salarios señalados a los guardas, y se dé cuenta a ese tribunal de esta pretensión y que resuelva.

\section{6}

1789/Abril/30. Canaria.

Junta con asistencia de D. Francisco de León y D. Isidoro Romero, regidores perpetuos.

D. Isidoro Romero dice que, habiéndosele encargado en esta Junta en la celebrada en 25 de febrero de este año el que junto a D. Andrés Cabrera diese las competentes disposiciones para la monda y descuajo del Monte Lentiscal, supliendo los costos con el producido de la leña por las favorables resultas que de dicho método se habían reconocido al practicarse durante diciembre del año pasado y enero del presente, dio principio a la ejecución de dicho encargo a mediados de la semana pasada; que habiéndolo iniciado se ha suspendido por orden del señor corregidor, así como la venta de la leña y la de los acebuches que arrancó de cuajo el viento en el huracán acaecido en el mes de febrero o enero; que siendo un despojo de las facultades que tenía el exponente, en virtud de lo mandado por la Junta y las competencias dadas por la Audiencia, le ha parecido ser de su obligación dar parte a la Junta para que resuelva. Y en su vista, se acordó que el escribano dé cuenta al corregidor de la exposición y del particular acordado en 25 de febrero para que deje libres las facultades de la Junta continuando Agustín Velázquez con la limpia de los árboles, y en caso de que necesite testimonio tanto de la exposición como del acuerdo se le dé por el escribano.

Escrito fechado en Canaria, en 27 de abril de 1789, de Antonio Rodríguez, vecino de la Vega, señalando que el tribunal le ha nombrado por sobreguarda mayor del Monte Lentiscal en 6 de enero de 1788 con la asignación de cincuenta pesos anuales; y que habiendo transcurrido un año acudió por memorial al Ayuntamiento de esta isla, quien hasta la fecha no le ha dado providencia, aunque lo ha solicitado en varias ocasiones, y por ser pobre y necesitar el dinero pide se le satisfagan dichos cincuenta pesos. Los señores de la Audiencia mandaron que pase a la Junta para que provea sobre la pretensión del susodicho. Y se acordó contestar a la Real Audiencia que, ni constándole la 
asignación de renta ni habiendo resuelto el tribunal de donde se ha de satisfacer las rentas de los guardas como se le tiene consultado, no puede la Junta dar providencia.

Se vieron los memoriales pidiendo licencia para sacar del pinar de D. Juan Ruiz de Quintana para la fábrica de una casa, gañanía, molino y alpendre, un palo cuadrado, como una tosa para sacar tablas, veintiocho vigas, trece palos de tosas para tablado, ocho horcones para una gañanía, dos vigas sencillas y dieciocho jubroncillos, doscientas cincuenta tijerillas de cuatro varas para armadura de un granero, casa, cocina y marcos de puertas, ocho palos llamados chaplones para dos puertas y diez jubroncillos, y cuatro horcones más para el techo de un alpendre para una caldera de estila.

Otro, de Miguel de Alemán, vecino de Gáldar, para un barco, que son siete palos de pie quebrado, treinta piezas redondas, cinco pequeñas, cinco henchimientos, siete palos de planes, dos costones y sobrecostones, un contracodaste, dos cintas de proa, diecisiete palos de aposturas, un timón de veintitrés palomos, dos curvas, seis docenas de tablado y los maderos para una lancha.

Y otro, de D. Manuel Padrón para sacar madera para el hospital de la ciudad, en concreto veinte vigas, veinte palos de tea, treinta jubrones, treinta tijeras y las soleras que se necesitan para sacarla. Se acordó conceder las licencias.

\section{7 \\ 1789/Mayo/4. Canaria.}

Junta con asistencia de D. Francisco de León y D. Isidoro Romero, regidores perpetuos.

Viendo la Junta que, a pesar de las prevenciones verbales que han hecho a los guardias de los montes de esta isla para que pongan en ejecución el artículo 13 de la instrucción que se les entregó sobre que formen causas preventivas a los que resulten reos contra dichos montes, lejos de ejecutarlo insisten en remitir denuncias, de las cuales son muy pocas a las que se ha dado curso, resultado de la impunidad, el desprecio de los mismos guardas e inobservancia de lo mandado. Se acordó que los guardas de los montes cumplan sin excusa ni omisión lo que se les tiene prevenido en cada uno de los artículos de la instrucción.

El escribano da cuenta de haber cumplido en todas sus partes con lo acordado en junta de 30 de abril llevando a la Audiencia las consultas que se le previnieron; y habiendo pasado a las casas del corregidor a hacerle presente todo lo acordado en dicha junta, dicho señor respondió que me abstuviese en el susecibo de semejantes gestiones por ser como son contrarias a el respecto y autoridad que en su mersed existe imanada de Su Majestad, pues en tal caso prosedería contra mi en los términos que hubiese lugar. Y enterada la Junta de esa respuesta, acordó que, sacando el escribano testimonio del particular relativo al Monte Lentiscal acordado en junta de 25 de febrero, de la exposición hecha por D. Isidoro Romero en junta de 30 de abril, de lo acordado en su consecuencia y de la respuesta que antecede, dé cuenta a la Real Audiencia a la mayor brevedad para que resuelva lo más conveniente, pidiendo la Junta a 
ese tribunal le prescriba el método en que se debe dar cuenta al corregidor de las providencias económicas que tome, ya que se niega a toda contestación verbal que le han ido a hacer en su casa algunos de los individuos de esta Junta.

\section{8}

\section{9/Mayo/18. Canaria.}

Junta con asistencia de D. Francisco de León y D. Isidoro Romero, regidores perpetuos, D. Andrés Cabrera, diputado del común, y D. Juan Reyes, síndico personero.

Habiéndose empezado a tratar de varios asuntos que están a cuidado de esta Junta, el señor síndico personero dijo que ha llegado a su noticia de que por mandato de la Real Audiencia, a consecuencia de la orden con que se halla al Real Consejo de Castilla sobre repartimiento de los terrenos baldíos y sobres de montes y montañas, se están reduciendo a suertes las que se han reputado faldas de Montaña de Doramas; y entre ellas, aquellos terrenos que en virtud de providencia del mismo tribunal se segregaron del primer señalamiento hecho a favor del Real Hospital de San Lázaro en el pago de Fontanales, y también los demás que en otros pagos se reservaron desde aquel tiempo por haberse reconocido arbolados, como que su reducción a cultura traería los considerables perjuicios que se tuvieron presentes en la acta general de la isla celebrada con motivo de dicha data del Real Hospital, y pues la experiencia ha acreditado que repartidas aquellas faldas de Fontanales tan recientemente se encuentran [h]oy otras que ya se jusgan dignas de su repartimiento, suponiendo el personero será por hallarse destituidas de árboles, sacamos claramente la conzequencia indubitable de que sucsesivamente se yrán reduciendo a faldas todos los terrenos de dicha Montaña, y esta a perderse enteramente, lo que acontezerá también con el Monte Lentiscal. Los perxuicios que con estas pérdidas se ynferirán a toda esta ysla y aún a toda la provincia tiene el personero por excusarlo el repetirlo quando están tan manifiestos en las diversas representaciones que se hallan hechas por los antecessores del exponente, realizando una exposición sobre los daños que se están haciendo.

D. Francisco de León dice que es su voto que el escribano saque testimonio de la representación antecedente y lo lleve a la Real Audiencia, a quien se suplique suspender el sorteo o repartimiento de las llamadas faldas de la Montaña de Doramas, Monte Lentiscal y Pinares, y mandando pasar a esta Junta los expedientes relativos dichos sorteos o repartimientos para representar lo que estime por más útil a la causa pública.

D. Isidoro Romero se conforma con el voto de D. Francisco de León en cuanto a suplicar a la Audiencia mande suspender el sorteo, pero no en cuanto a que se pasen a la Junta los expedientes relativos a la discreción que se ha hecho por los pueblos de las sobras de montes, porque considera que esta diligencia, lejos de producir utilidad alguna por las ningunas luces con que se halla el exponente, más bien acarrearia un origen de contestación con los diversos pueblos; y duda que no podrán resolverse en mucho tiempo sin notable perjuicio a los habitantes de la isla, por lo cual le parecía más conforme preceda al dicho sorteo el amojonamiento general que tiene pedido y 
representado en junta de 31 de octubre pasado asistiendo algún señor de esta Junta o del Ayuntamiento.

D. Andrés Cabrera dice que es su voto que se suplique a la Audiencia mande suspender el sorteo por las razones que expresa el señor síndico, y que cualquier porción que se les desmembren causarán un daño considerable, y se suplique a dicho tribunal mande reintegrar a dichos montes las porciones que sin justo título se hayan desfalcado de ellos desde el deslinde hecho por el corregidor D. Nicolás de la Santa hasta el presente.

Memorial presentado por Francisco Gil de Vega, vecino en Valsequillo, pidiendo licencia para sacar treinta cargas de madera de tea, a que acompañó relación jurada del maestro Juan Bernardino como encargado de la obra de la ermita de San Miguel de dicho pago para quien es la madera. Se acordó conceder la licencia.

\section{9}

\section{9/Mayo/23. Canaria.}

Junta con asistencia de D. Isidoro Romero, regidor perpetuo, y D. Andrés Cabrera, diputado del común.

Memorial con memoria jurada de D. Manuel del Río, regidor y vecino de esta ciudad, para sacar madera del pinar, veinte jubrones y nueve tijeras, para fabricar una casa en la hacienda de la Vega por el maestro Antonio Ortíz.

Memorial de Vicente Quintana, vecino de Tejeda, pidiendo licencia para sacar madera del pinar con memoria del oficial Miguel Francisco, vecino de ese lugar, que son trescientas catorce tijeras, treinta y seis jubrones, diez cumbreras, quince palos y seis vigas con las soleras para arrastrar dicha madera, para la fábrica de cuatro casas, dos de alto y dos terreras.

Se acordó dar la licencia.

\section{0 \\ 1789/Mayo/27. Canaria.}

Junta con asistencia de D. Isidoro Romero, regidor perpetuo, y D. Andrés Cabrera, diputado del común, y D. Juan Reyes Cabrera, síndico personero.

Se hizo saber por el receptor D. José Alvarado un auto de la Real Audiencia de 25 del corriente por el que no ha lugar la pretensión de la Junta de Montes de 18, del sindico o del cuerpo capitular de esta isla, teniendo que pedir y exponer sobre el repartimiento de baldíos mandado hacer, y lo practique en la Audiencia.

Y otro auto de la Real Audiencia de 27 de abril de 1789 en el que, habiendo visto el acuerdo celebrado por la Junta en 22 de diciembre pasado sobre que el tribunal tome las providencias convenientes para el amojonamiento y deslinde de la Montaña de Doramas y demás contenido, dijeron que la Junta cele y evite las usurpaciones de los montes y montaña; y en cuanto a las hechas anteriormente, use de su derecho el personero por los medio legítimos sin innovar. 
También hizo saber otro decreto, de 5 de mayo, del citado tribunal proveído a causa de una representación del corregidor D. Vicente Cano de esa misma fecha, sobre la autorización de la Junta a sacar la leña del desbroce y que con la venta de ella se pague ese trabajo, así como sobre funciones en estas cuestiones de la Junta, para que en su vista informe de lo que se le ofreciere. Y se acordó se llame a junta.

Memorial jurado de Andrés Robaina, vecino del valle de Casares en Telde, para sacar madera del pinar con la memoria del carpintero Manuel Suárez, vecino de dicho lugar, para una casa que va a fabricar, y que será una cumbrera, seis tosas, treinta jubrones, sesenta tijeras y dos vigas. Se acordó conceder la licencia.

Memorial de D. Gregorio Alberto de Medina, presbítero vecino de la Vega, para sacar del pinar treinta cargas de rama para la festividad de San Antonio que se celebra en la parroquial de dicho pueblo de la Vega. Se acordó que en atención a que por bando público se halla prohibida toda enramada, assí en la capital como en los pueblos de la ysla, por evitar los perxuicios que en un corte se causa a los montes, no se concede la licencia.

\section{1}

\section{9//Junio/22. Canaria.}

Junta con asistencia de D. Francisco de León y D. Isidoro Romero, regidores perpetuos, D. Andrés Cabrera, diputado del común.

Memorial de D. Félix, mayordomo del palacio episcopal, pidiendo licencia para sacar y cortar de la Montaña de Doramas ciento cincuenta cargas de leña para el consumo del gasto de dicho palacio. Se acordó conceder la licencia con tal que sea del paraje donde menos perjuicio se siga a dicha Montaña.

32

\section{9/Junio/30. Canaria.}

Junta con asistencia de D. Francisco de León y D. Isidoro Romero, regidores perpetuos, D. Andrés Cabrera, diputado del común, y D. Juan Reyes, síndico personero.

El receptor de la Real Audiencia, D. José Alvarado, exhibe un auto de ese tribunal, dado en Canaria en 20 de junio de 1789, en el que, habiendo visto el expediente sobre el conocimiento económico y gubernativo de los montes de esta isla y las siete consultas hechas a la Real Audiencia desde 25 de junio del año pasado, resuelven sobre dichas consultas: a la primera, que continúe presidiendo la Junta el más antiguo celebrando una en día cierto de cada semana, y en ella se concedan, extiendan y firmen las licencias para cortes; a la segunda, que los sobreguardas de la Audiencia dirijan sus denuncias a la Junta, dejando esta la nota conveniente en un libro que se debe tener solo para esto y las pase con oficio al corregidor para que proceda conforme a derecho; a la tercera, que los alcaldes de los pueblos contiguos al Monte, pinar y Montaña faciliten a los tenientes de guardas los obreros que pidan para hacer replantos y sementeras, asistan para darles actividad y se pagará de 
jornal 4 reales de vellón de los que entran en los propios de los montes mismos, como son parte de multas, arriendo de abejas salvajes y guaniles; en la cuarta, que se haga como se propone, entendiéndose las cuatro campañas cuatro años de servicio en uno de los regimientos fijos de los presidios de África; en la quinta, que a cada uno de los tenientes de guarda de la ciudad, dos del pinar, dos de la Monta y uno del Monte Lentiscal, se satisfagan sus salarios de 50 pesos de los caudales que entran en propios de los montes mismos y también la parte de muchas de las denuncias que se han hecho; en la sexta, que al sobreguarda de la Audiencia del Monte Lentiscal se le den por ahora 25 pesos de aquella porción que de las multas corresponde a penas de cámara; y en cuanto a la séptima, que se aprueban los capitulos adicionados al reglamento, entendiéndose la presencia de los tenientes de guarda de la ciudad a las costas solo para el señalamiento, y siendo responsables los fragueros si después apareciese exceso o fraude en aquel sitio, y contribuyan los interesados por este señalamiento 8 reales de vellón, siendo la costa para construcción, y pasando de tres pies de árbol, y se hagan los demás sin estipendio. Además, señala que Divídase Montaña y pinal en dos partes y cométase con esta ceparazión a cada uno de los quatro tenientes de Guarda de la Ciudad el cuydado y zelo de la parte que se le señale. Debuelban las lizencias a la Junta con él cumplidas dentro del término que lleben señalado y manifiéstenlas a los sobreguardas de la Audiencia si las pidieren para que puedan cumplir con el encargo que les está cometido.

También exhibió dicho receptor D. José Alvarado las denuncias que D. Juan Antonio Domínguez, teniente sobreguarda de la Montaña de Doramas, presentó a dicho tribunal en 12 de marzo y 15 de junio de este año.

Y vista todo, se acordó se llame a Junta para el lunes 6 de julio a las nueve en punto de la mañana.

Se presentó memorial de Ildefonso de Santa Ana, vecino de esta ciudad y dueño del barco del tráfico de la costa San José, diciendo que dicho barco se halla sin las dos lanchas que llevó a la costa a causa de habérselas hurtado los moros africanos; y para no demorar el viaje solicita licencia para cortar en la Montaña de Doramas la madera para poner dos lanchas en lugar de las perdidas. La Junta concede la licencia asistiendo el guarda únicamente al señalamiento del sitio donde han de hacer el corte por lo que se le contribuyan 8 reales.

\section{9/Julio/6. Canaria.}

Junta con asistencia de D. Francisco de León y D. Isidoro Romero, regidores perpetuos, D. Andrés Cabrera, diputado del común, y D. Juan Reyes, síndico personero.

Habiéndose pasado a conferir sobre el auto de la Real Audiencia extendido en la junta antecedente, se acordó que antes de procederse a otra cosa diga el señor síndico lo que tiene que exponer. El cual dice que tiene que exponer que es gravosa a los gremios de labradores y mareantes de esta isla la contribución de 4 reales vellón por las licencias que obtengan, que ambos gremios se hallan 
exentos de toda contribución de derechos e impuestos que puedan causar trabas a su fomento, y con este estímulo siempre ha sido libre la saca de dichos aperos y útiles de pesca, aunque para evitar fraudes la ciudad resolvió que los mareantes solicitasen la licencia oportuna para su saca pero sin cobrarles derechos, lo cual tiene aprobado la Real Audiencia. Viendo que ya eran las 12 del mediodía, se acordó continuar mañana a las 9.

\section{4}

\section{9/Julio/7. Canaria.}

Junta con asistencia de D. Francisco de León y D. Isidoro Romero, regidores perpetuos, D. Andrés Cabrera, diputado del común, y D. Juan Reyes, sindico personero.

Habiéndose vuelto a tratar sobre el auto de la Real Audiencia resolviendo las siete consultas y lo expuesto por el síndico personero general, por no haber habido conformidad se mandó votar.

D. Francisco de León dijo que es su dictamen se guarde y cumpla y ejecuta cuanto en dicho auto se previene, remitiendo testimonio al corregidor.

D. Isidoro Romero dice que venera el auto de la Real Audiencia y que se ponga en ejecución; pero sobre la extinción de los guardas mayores de que ha estado la ciudad en posesión de nombrar entre sus individuos cada año y sobre el final que se ha de dar a los vecinos de los pueblos en los plantíos que se ofrezcan, es de parecer que se suplique a dicho tribunal se digne conservar dichos guardas mayores con el pie que siempre han gozado en las licencias que se libran. En lo que atañe a la propuesta hecha por el síndico personero, es del mismo dictamen: que no se les lleve derechos, pero que deban sacar la licencia correspondiente.

D. Andrés Cabrera dice que es su dictamen se ponga en ejecución el auto de la Real Audiencia y se suplique al mismo tribunal se digne modificar la providencia en cuanto a liberar a los mareantes del impuesto que se les carga por las licencias que deban sacar, y en lo demás es del dictamen de D. Francisco de León.

Y en vista de la variedad de dictámenes, se acordó pase el escribano a hacer relación de ellos y de lo expuesto por el sindico a la Real Audiencia para que resuelva lo que estime por más conveniente. Y para empezar a dar cumplimiento a las providencias dadas, se señala el lunes de cada semana a las 9 de la mañana.

Memorial de D. Bartolomé Morales pidiendo licencia para ciento cincuenta cargas de leña de la Montaña de Doramas para barrote y fornecimiento del barco Loreto, de Francisco Suárez, que está próximo a hacer viaje a La Habana.

Otro memorial del provisor general del convento de San Francisco de esta ciudad, pidiendo cien cargas de leña para su consumo.

Otro memorial de Josefa Gil para cortar madera de la Montaña de Doramas para fabricar un barco de la costa, con memoria que presenta y que son cien 
palos de ligazón, codaste, roda, aletas, sobrequilla, cuatro palos de cinta, yugo, madera para dos lanchas y veinte docenas de tablas de pino.

Otro de D. Francisco Suárez Romero, presbítero vecino de Aguimes, mayordomo de la iglesia de Nuestra Señora de la Candelaria de Ingenio, de madera del pinar para fenecer la obra de dicha iglesia, y con lista jurada que consta de dieciocho tosas, treinta vigotes de a cinco varas y media de largo y palmo y torno en cuadra, doce vigas regulares, cuatro vigas de a siete varas y media, dos vigas de nueve varas y media y cuarenta y dos jubrones cuadrados.

Se acordó conceder todas las licencias.

\section{5}

\section{9/Julio/20. Canaria.}

Junta con asistencia de D. Francisco de León y D. Isidoro Romero, regidores perpetuos, y D. Juan Reyes, sindico personero.

Memorial de D. Nicolás Massieu Sotomayor solicitando licencia para conducir a esta ciudad cien cargas de leña de la que diariamente se está sacando por los leñadores de la Montaña de Doramas para el gasto de su casa. Se acordó que, sin embargo de que a la Junta solo corresponde el conceder licencia para los cortes de árboles que se hagan en los montes, por ahora y hasta que con más conocimiento se resuelva sobre la materia, se concede la licencia. El escribano protesta el acuerdo, apela ante la Real Audiencia, y la Junta acordó se le oye la apelación y en ambos efectos con tal que evacue el recurso en tercer día.

El sindico personero general, habiendo oído la contestación del memorial presentado por D. Nicolás Massieu, dijo que el objeto con que están establecidas las licencias es para la corta de árboles necesarios para construcciones u otros usos pero que, de ningún modo, se han establecido para que sin ella no se pueda sacar ni extraer la leña seca de la Montaña de Doramas, pues esto se opone al indispensable surtido que necesitan todos los vecinos de la isla. Si el objeto de la licencia recae sobre allanar el paso para aquellos pueblos, supuesta la general prohibición de que se extraiga este abasto para las otras islas, le parecía al personero estaba cortada dicha extracción con que se encargase el celo en los embarcaderos, ya sea a los alcaldes de los pueblos, ya a los guardas de los montes; y concibe el personero que el maestro del barco que carga de leña para esta ciudad cumple con traer nota firmada por el alcalde o guarda en que conste el número de cargas de leña que conduce, cumpliendo con exhibirlo al tiempo que aporte al sujeto sujetos que estén cargados de este celo.

En vista de lo expuesto por el síndico, D. Francisco de León dijo que está de acuerdo con lo que dice el síndico, y en su dictamen se debe ejecutar.

D. Isidoro Romero dice que no se opone a la libre circulación de leña para el surtido de los pueblos, pero que deberia hacerse distinción entre las que van por tierra de las que lo hacen por mar.

En vista de la variedad de dictámenes, se acordó pase el escribano a la Real Audiencia con testimonio del acta y resuelva ese tribunal superior. 
Entró D. José Alvarado, receptor, y presentó un certificado de 10 de julio de 1789 de D. José Antonio Pérez, escribano de cámara y del acuerdo de la Real Audiencia, de cómo, en un escrito presentado el 7 de julio de 1789 a este tribunal por la Real Sociedad Económica de Amigos del País de esta isla relativo a contener el reparto de terrenos baldios de faldas de montes y montañas con solicitud de replanto y aumento de arbolado, consta un punto en el que señala que, a pesar de la protección del Monte Lentiscal, la venta de troncos y el desbroce que se está haciendo tiene algunos inconveniente, por lo que solicita la prohibición de la venta de troncos o se mande que estos se extraigan enteros en un término señalado, así como mandar que la limpia se haga en estación oportuna a presencia de sujeto de respeto; y la Real Audiencia manda se haga como lo pide la Real Sociedad, para lo cual se pase testimonio a la Junta de Montes que lo haga ejecutar y cuide su cumplimiento. Se acordó se tenga presenta para resolver sobre la materia el lunes próximo.

Se presentaron dos memoriales. Uno, de D. José González, vecino de San Lorenzo en el Dragonal, pretendiendo sacar del pinar madera para la fábrica de una casa con lista jurada del oficial de carpintero Blas Melo. Otro, de Sebastián López, vecino de esta ciudad en el pago de Tafira, pretendiendo sacar madera del pinar para la fábrica de una casa, el cual presenta lista jurada del oficial de carpintero Blas Melo. Se acordó se les despache las licencias.

También se presentó un memorial de los vecinos de Gáldar pidiendo sacar de la Montaña de Doramas cuarenta horcones y trescientas latas y rama para el toldo; se acordó que se concede la licencia en cuanto a los horcones y latas y se deniega en cuanto a las ramas, haciéndose el corte con intervención de los tenientes de guardas.

\section{6}

\section{9/Julio/27. Canaria.}

Junta con asistencia de D. Francisco de León, regidor, D. Andrés Cabrera, diputado del común, y D. Juan Reyes, síndico personero.

Habiéndose tratado sobre la providencia de la Real Audiencia de 10 de julio sobre lo pretendido por la Real Sociedad Económica de Amigos del País de que se suspenda el desbroce y saca de leña del Monte Lentiscal, ejecutándose solo lo uno y lo otro en el tiempo y bajo las reglas que propone dicho cuerpo, se acordó se obedece dicha superior providencia y se cumpla, pasándose providencia al corregidor por medio del competente oficio. Y en este estado, el síndico personero dijo que en la mañana de este dia se hallava en la sala del despacho del señor corregidor y se movió comberzación en la materia, que dicho señor le expresó que haviendo llegado a entender el citado mandato del tribunal en razón de la prohivición de desbrose y saca de leña havia comunicado su orden para que assi se cumpliese al teniente de guarda del Monte, Agustín Belazquez, prebiniéndole a Juan Asevedo, sobrestante de la obra de cañería y fábrica de loza, no reciviese para ella más leña de dicho desbrose, sin embargo de faltar seis o siete cargas para quemar la última jornada, lo que assí afirmó el mismo sobrestante que se hallava presente y le encargó al personero lo hisiese assi presente a la Junta para si tuviese a bien no cansarse en pasarle oficio sobre la materia. Y en vista de ello, se acordó se suspenda el oficio dispuesto aunque se comunique la orden competente al guarda y sobreguarda. 
En cumplimiento de lo mandado por la Real Audiencia en el auto de 20 de junio, se acordó que para la primera que se celebre traiga el escribano los dos libros que se necesitan para las anotaciones que se previenen por ese tribunal.

El escribano da cuenta de haber pasado el oficio al guarda del Pinar para que se verifique la división del mismo, y se acordó que debido a la urgencia y a que se pueda extraviar se le repita otra, incluyendo al alcalde de Tejeda para que se la haga entregar en mano.

\section{7}

\section{9/Agosto/5. Canaria.}

Junta con asistencia de D. Francisco de León, regidor perpetuo, y D. Andrés Cabrera, diputado del común.

D. Francisco de León dice que D. José Alvarado, receptor de la Real Audiencia, le entregó el lunes 3 de agosto la resolución de dicho tribunal a la consulta que le hizo la Junta el día 20 de julio, y que es el siguiente:

Auto de la Real Audiencia de 21 de julio de 1789 en el que, habiendo visto el testimonio relativo a la licencia que solicita D. Nicolás Massieu para conducir de la Montaña de Doramas a esta ciudad cien cargas de leña para el pasto de su casa y los dictámenes expuestos sobre ello por los miembros de la Junta, manda que la Junta reduzca sus licencias a la del corte dentro de los montes y se abstenga de hacer remisión de los derechos señalados a los oficiales de justicia; que los barqueros puedan traer sin obstáculo alguno, solo con el pase del alcalde del pueblo en cuyo distrito se embarque la leña, todo lo que allí comprasen o fletasen de otro, y dicho alcalde dará razón mensual de los que se hubiesen concedido al corregidor y la Junta con separación, para evitar la extracción a otras islas o países.

Y en su vista se acordó obedecer y guardar y se saque testimonio para pasarlo al lugar de Gáldar y otros lugares si fuere necesario.

Haviendose tratado en esta Junta sobre que es mui regular el que algunas personas y comunidades de esta ciudad piensen [h]azer enramada para adornar los frentes de las casas o conventos por donde pase el real pendón el día veinte y cinco del corriente señalado para hacer la real proclamación de nuestro augusto soberano el señor don Carlos quarto, se acordó el que por solo este motivo se conceda licencia a los que la pidan para poder cortar y sacar de la Montaña de Doramas y pinales las ramas que necesiten, pero de ningún modo del Monte Lentiscal. Y con la expresa condición de que dichas ramas se han de cortar sin causar el más leve perjuicio a los pies de los árboles ni a los gajos principales de ellos, pues la porca y pendón deben quedar intactos. Y se concede al señor Isidoro la licencia que ha pedido para traer treinta cargas de rama de la Montaña de Doramas y demás que se pidan.

Memorial, con lista jurada del oficial, de D. Miguel Carrascosa, presbítero vecino de esta ciudad, queriendo sacar del Pinar veinte vigas, treinta tosas, sesenta jubrones, cien soleras y veinte palos para fabricar una casa y gañanía en Jinámar. Se concede la licencia.

Memorial de Joaquín García, vecino de Tejeda, pidiendo licencia para cortar madera del Pinar para pagar algunos encargos que tenía antes que se formase 
la Junta, veinte palos o tosas, veinte vigas y sesenta jubrones con las correspondientes soleras. Se concede.

Memorial de José Cristóbal, vecino de Moya, con lista jurada del oficial para sacar de la Montaña para la fábrica de una casa una cumbrera, un pie derecho, veinte jubrones, cuarenta tijeras y cuatro tosas para puertas y ventanas. Se concede.

Memorial de D. Miguel Carrascosa, vecino de esta ciudad, para sacar del Pinar cien tijeras, ochenta jubrones, treinta vigas, treinta y cinco tosas y veinte palos para la fábrica de dos casas y gañanía en la Vega. Se concede.

Memorial de D. Antonio Betancur, vecino de esta ciudad, con su lista jurada para sacar del Pinar dieciocho vigas, veinte tosas, noventa jubrones, sesenta tijerones y cuarenta soleras para la fábrica de una casa. Se concede.

Otro memorial de D. Nicolás Massieu Sotomayor para sacar de la Montaña de Doramas dos mil horcones y quinientas latas para los parrales que tiene en esta isla. Se concede.

Memorial de José Flores, vecino de esta ciudad, con lista jurada del oficial para sacar del Pinar madera para roda, codaste, aletas, yugo, sobrequilla, trancaniles, seis palos, cuatro palos de cinta, veinte latas, cien palos de ligazón, dieciséis docenas de tablas, dos costones que necesita para fabricar un barco para la costa de África del pescado salado. Se concede.

\section{8}

\section{9/Octubre/22. Canaria.}

Junta con asistencia de D. Isidoro Romero, regidor perpetuo, y D. Francisco de la Ysequilla, diputado del común.

Se presentaron varios memoriales solicitando licencia para sacar madera del Pinar y la Montaña de Doramas, que son los que siguen:

- Blas de Miranda, vecino de esta ciudad, pidiendo licencia para sacar del Pinar dos rodas, veinticinco piezas de ligazón, cuatro manos de cinta, seis docenas de tablas y la madera para una lancha y ocho soleras, para la fábrica de un barco del tráfico de esta isla.

- D. Juan Navarro, vecino de esta ciudad, pidiendo licencia para sacar del Pinar treinta tosas, treinta jubrones, treinta vigas y las soleras necesarias su transporte, para la fábrica de una casa.

- Agustín Romero, vecino de Telde, pidiendo licencia para sacar del Pinar diez tosas, veinticinco jubrones, otros diecinueve jubrones, una viga y cuarenta tijeras para la fábrica de una casa en Telde.

- Ildefonso Cayetano de Santa Ana. pidiendo licencia para sacar de la Montaña de Doramas cuatro manos de cintas dobles y cuarenta palos de ligazón para la composición de un barco de la costa de pescadería de la Costa de África.

- Josefa Gil, vecina de Canaria, pidiendo sacar del Pinar cien jubrones, doce tosas, seis ligas y las soleras necesarias para su transporte, para la fábrica de una casa. 
Se acordó conceder todas las licencias.

\section{9}

\section{9/Noviembre/6. Canaria.}

Junta con asistencia de D. Isidoro Romero, regidor perpetuo, y D. Andrés Cabrera, diputado del común.

Se presentaron varios memoriales solicitando madera:

- D. Juan de Castro, clérigo presbitero, vecino de esta ciudad, pretendiendo sacar treinta jubrones, veinticinco tijerones y dos tosas del Pinar, según la lista jurada de Domingo de Gracia Sánchez, oficial de carpintero, para la fábrica de una casa.

- D. Domingo Galdós, vecino de esta ciudad, pidiendo licencia para sacar cien jubrones, diez vigas, seis tosas y ciento veinte soleras del Pinar, para la fábrica de una casa según lista del oficial José Talavera.

- José Martín, vecino de la Aldea de San Nicolás, pidiendo licencia para sacar sesenta jubrones, ciento cincuenta tijeras, treinta vigas y veinte tosas del Pinar

- José Antonio Talavera, vecino de esta ciudad y oficial de carpintero, pidiendo sacar treinta jubrones, diez tosas y seis vigas, para la fábrica de una casa propia.

Se acordó conceder las licencias con las calidades prescritas; y se acordó conceder una viga doble de siete varas que necesita D. Francisco del Castillo para dar cumplimiento al encargo de la composición de la carnicería que le hizo la ciudad y otras dos vigas para la recova.

40

1789/Noviembre/24. Canaria.

Junta con asistencia de D. Isidoro Romero, regidor perpetuo, y D. Andrés Cabrera y D. Francisco de la Ysequilla, diputados del común.

Se presentó memorial de D. Andrés Barreto, vecino de esta ciudad, con lista jurada pretendiendo licencia para sacar treinta y dos tosas, treinta y dos vigas y ochenta jubrones del Pinar, para la fábrica de una casa suya en Telde. Se concede.

\section{1}

\section{9/Diciembre/7. Canaria.}

Junta con asistencia de D. Isidoro Romero, regidor perpetuo, y D. Andrés Cabrera y D. Francisco de la Ysequilla, diputados del común.

D. José Alvarado, receptor de la Real Audiencia, hizo saber un auto de ese tribunal de 26 de noviembre. De lo que se deduce cuando se leyó, porque no dejó el auto ni copia del mismo, que se reduce a resolver la duda propuesta por esta Junta en la celebrada en 7 de Julio de este año, relativo a que dicho tribunal se sirviese reformar, a petición del síndico, lo dispuesto en otro auto del mismo tribunal de 20 de Junio de este año en que se ordenaba que los 
labradores pagasen por la licencia de sus aperos 4 reales y lo mismo los mareantes por galápagos, toletes y varas cobrándose los 4 reales para el escribano, y que no habia lugar a la pretensión del síndico ni a la de los guardas mayores sobre cobrar derechos. Se acordó se guarde y cumpla, pasándose aviso a los tenientes de guardas mayores y sobreguardas de la Real Audiencia.

La Junta, en cumplimiento del auto de 20 de junio, manda que el escribano dé cuenta de las denuncias que hayan pasado ante sí, su estado y penas impuestas a los denunciados para anotarlo en el libro que se acordó hacer para este fin.

Memorial de Juan de Santa Ana Ortega, vecino de Valleseco, pretendiendo licencia para sacar tres vigas de til y tres majadas de a ciento veintiséis escaleras cada una de la Montaña de Doramas para un rebaño de ovejas. Se acordó concederla.

\section{2}

\section{0/Enero/22. Canaria.}

Junta con asistencia de D. Isidoro Romero, regidor perpetuo, y D. Francisco de la Ysequilla, diputado del común.

Habiéndose visto las denuncias presentadas por el sobreguarda D. Juan Antonio Domínguez en la Real Audiencia el 19 de este mes ante ese tribunal, el cual mandó pasasen a esta Junta, y no hallándose conformes a lo que se previene en el capítulo 5 párrafo 13 del nuevo arreglo de montes de que vengan justificadas competentemente con algún testigo, lo que acordó esta Junta se le hiciese saber de nuevo a los tenientes de guarda y subtenientes por su acuerdo de 7 de diciembre pasado, acordó se le devuelvan al dicho D. Juan Antonio para que las formalice según y cómo está mandado el capítulo 13 del nuevo arreglo de gobierno de montes de esta isla.

Memorial de D. José Mederos, clérigo presbítero, vecino de Artenara, solicitando licencia para sacar del Pinar diecisiete tosas, treinta y cuatro vigas y veinticuatro jubrones, con las soleras correspondientes para arrastrar dicha madera, para la fábrica de la iglesia de San Mateo del lugar de la Vega, como encargado que es de dicha obra.

Memorial de José Ponce, vecino de esta ciudad, pidiendo licencia para sacar treinta piezas dobles de ligazón entre ginchimientos ${ }^{11}$, piques y planos, diez piezas redondas y diez viertas, quince piezas dobles, seis manos de cintas, ocho palos de bao dobles, su roda y codaste, quilla, aletas, timón, arboladura, lancha y doce docenas de tablas del Pinar para la fábrica de un barco del tráfico a las islas. Se le concede la licencia.

1790/Febrero/4. Canaria.

Junta con asistencia de D. Isidoro Romero, regidor perpetuo, y D. Francisco de la Ysequilla, diputado del común.

Se vieron los memoriales siguientes:

$11 \mathrm{Sic}$ 
- Del alférez mayor D. Francisco del Castillo, para sacar de la Montaña de Doramas madera para la construcción de seis bomberos, tres docenas de palas de embarrar y tres docenas más de boca, para el trabajo de la sal.

- De D. Domingo Galdós para sacar del Pinar cien jubrones, quince tosas para tablado, quince palos para tablazón de un barco, un timón, cuatro palos para arboladura, un palo para una bomba, dos latas para el combés del barco y tablas de solladio, según lista jurada del oficial de carpintero de ribera para un barco.

- De Pedro Montesdeoca, vecino de Firgas, para sacar de la Montaña de Doramas cien yugos y cien arados para surtir a los labradores, según encargos que le han hecho como fraguero que es.

Se les concede licencia en la forma acostumbrada.

44

1790/Febrero/11. Canaria.

Junta con asistencia de D. Isidoro Romero, regidor perpetuo, y D. Francisco de la Ysequilla, diputado del común.

Habiendo citado por José Arzola, portero, a D. Francisco de León, le respondió que ya le había dicho no se cansase en irle a citar así para esta Junta como para cabildos mientras que no se hallase enteramente bueno; y que igualmente había citado a D. Dámaso Hermosilla, síndico personero general, quien no le había dicho cosa alguna.

Se vio un memorial de Juan Almeida, teniente de guarda mayor nombrado por esta Junta en la Montaña de Doramas, vecino de Guía, en la que dice que, con motivo de la orden que tiene para hacer retirar los ganados de dicha montaña y puesto en ejecución, esta diligencia no ha tenido efecto, antes por el contrario un día por la mañana amaneció un papel a la puerta de mi casa disiendo no me metiese con ganados porque me podría suseder mal, que quidase de lo demás y dejase dichos ganados. Y otra noche se asercaron a mi casa como cosa de ocho o nueve homvres enmonterados y tocando a la puerta, y lebantándome a la ventana expresó uno de ellos que venían de parte de los criadores solo avisarme no apurara que los ganados saliesen de la Montaña, porque de haserlo assi iría a la Montaña y no vendria en mis pies para mi casa. Todo esto, señor, lo he echo presente a el señor corregidor, como tamvién el temor que tengo de pasar a celar dicha Montaña. Y hasta ahora ha havido providencia por donde dichos ganados salgan de la Montaña, lo que me muebe a representarlo a vuestra señoría a fin de que esta comisión de alojar los ganados fuera de la Montaña se cometa a los respectivos alcaldes sircunvesinos, a quienes obedeserán como corresponde los ganaderos, o que vuestra señoría delibere lo que más convenga.

En vista del memorial presentado, la Junta separa a dicho teniente de guardia del encargo y nombra a D. Gregorio Ponce Diaz, vecino de Arucas, y para obtener la aprobación correspondiente pase el escribano con testimonio de todo a la Real Audiencia, pasándosele en caso de la confirmación aviso para que acepte y haga el juramento. 
Teniendo la Junta presente lo que dispone el auto de la Real Audiencia de 3 de octubre de 1788, autorizándola para que pueda nombrar individuo sustituto en lugar del que se ausentase, acordó nombrar en lugar del señor D. Francisco María [de León], que se halla imposibilitado de asistir por indisposiciones, al señor D. Manuel del Río, y pase el escribano a la Real Audiencia con testimonio para su confirmación. Y por no haberse copiado en el libro, se transcribe a continuación.

Memorial de Catalina González, vecina de Guía, para sacar de la Montaña de Doramas la madera que consta en la memoria jurada del oficial Sebastián de León para la fábrica de una casa, y que son veinte vigas, diez jubrones y un palo. Se concede la licencia.

Se acordó pase oficio al corregidor del nombramiento de guarda de la Montaña de Doramas en D. Gregorio Ponce Diaz, vecino de Arucas, que fue aprobado por decreto de la Real Audiencia de 13 del corriente.

Memorial de Pedro Gil Marrero, pidiendo licencia para madera de una casa. Se concede.

\section{5}

\section{0/Febrero/25. Canaria.}

Junta con asistencia de D. Isidoro Romero, regidor perpetuo, y D. Francisco de la Ysequilla, diputado del común.

D. Isidoro Romero manifiesta una carta que se dirige a esta Junta desde la Real Sociedad de Amigos del País por medio de su vicedirector, D. Luis de la Encina, que es del tenor siguiente:

Muy señor mio, la Sociedad Económica de Amigos de esta ysla, haviendo //186rto tenido notizias fidedilg]nas de que el Monte Lentiscal se halla ya expuesto a la siega de yerva, a la saca de tierra y a los cortes de leña que señaladamente asen con toda libertad los que la traen al proveleldor de la tropa, y [h]arán otros muchos que no se conocen. Y considerando que el [h]azer esto en el año presente $y$ en los que sigan asta el entero restablecimiento deste Monte aniquilado es lo mismo que no haver adelantado cosa alguna con la absoluta prohivisión que se observó en el año pasado, pues se ba a malograr todo lo que entonces se adelantó por este cuerpo patriótico, que no dudó gastar sus caudales y aplicar la solicitud de algunos de sus sosios para verificar su replanto mediante la seguridad que vuestra señoria le dio por sus oficios de la vixilancia que pondria en su custodia. Y entendiendo que este havandono //186vto que sufre el Monte nace del retiro que a echo el celoso guarda puesto por la Real Audiencia, llamado Antonio Rodríguez, por no haver podido lograr como dize la paga de su salario y ser un pobre que no puede de histraerse de sus ocupaciones y emplearse en esta custodia sin estipendio, a acordado que yo a su nombre pasase a vuestra señoría el presente oficio exponiéndole a su consideración todo lo que llevo referido y suplicándole a su nombre, como lo executo, que vuestra señoría se sirva facilitar la paga de su trabaxo al dicho guarda, al qual desde que la Sociedad a tenido estas noticias a procurado sostenerle y alentarle a que no habandone el Monte enteramente, gratificándole con dinero y prometiéndole el mediar con vuestra señoría para verificar su justa recompensa; $y$ asimismo 
//187rto que atienda por todos medios a la exacta custodia del referido monte del mismo modo que lo hizo en el año próximo pasado, tanto para que no se acave de perder lo adelantado como para que este cuerpo patriótico pueda con seguridad azer los nuevos plantios y siembra que tiene determinado [h]azer quando la tierra tenga sasón para que se execute con provecho. Todo lo que espera la Sociedad, asi del amor que reyna y debe reynar en vuestra señoría para con el público, que sufrirá unos daños eyreparables si llega a su total desolación este Monte que corría ya a su entera ruina si no se hubiera tratado de su restablecimiento; y bolverá a correr a ella si se buelbe a abandonar este restablecimiento emprendido, como //187vto también de las repetidas promesas que vuestra señoria [h]a [h]echo a este cuerpo patriótico de que será custodiado el Monte con la maior vixilancia, en fuerza de las quales se a dedicado a gastar y trabajar en él y a las que no es criyble que vuestra señoria quiera faltar. Nuestro Señor guarde a vuestra señoría muchos años. Canaria, y febrero, veinte y dos de mil setecientos y noventa. Besos las manos a vuestra señoria su atento servidor $y$ capellán, Luis de la Encina, vicedirector. Muy ilustre Junta de Montes desta ysla de Canaria.

Se acordó contestarles por medio de D. Isidoro Romero, y se saque testimonio del oficio de ese cuerpo y se pase a la Real Audiencia para que se sirva resolver sobre su contenido. Y también se sacará testimonio del nombramiento hecho por esta Junta en el señor regidor D. Manuel del Río de miembro interino de esta Junta en lugar de D. Francisco de León por hallarse enfermo, pasándolo también al Real Acuerdo para tener su confirmación. Y se haga saber por el escribano al teniente de guarda Agustín Velázquez y al sobreguarda José Rodríguez continúen en su celo como hasta aquí.

\section{6}

\section{0/Febrero/26. Canaria.}

Junta con asistencia de D. Isidoro Romero, regidor perpetuo, y D. Francisco de la Ysequilla, diputado del común.

D. Isidoro Romero dijo que, habiendo entendido el señor personero D. Dámaso de Hermosilla de que el exponente había prevenido al escribiente de la ciudad José Guillermo para que sacase testimonio del oficio de la Real Sociedad que se vio en Junta el día de ayer para remitirlo a la Real Audiencia, le mandó, estando presente el que expone, el escribano de cámara de dicho tribunal D. José Peniche y el escribano D. Carlos Vázquez, el dicho señor personero al referido amanuense no sacase testimonio alguno de la Junta de Montes sino únicamente los que fuesen suyos o del Ayuntamiento y los podría sacar siempre que se los pagasen, pues no tenía obligación de servir a esta Junta arrogándose autoridades. Y mandó que sólo pertenecen al señor corregidor y Ayuntamiento congregado, cuyo procedimiento con los antecedentes de haber proferido en desprecio de la Junta, y por consiguiente con poco respeto del tribunal que la ha creado en el mismo oficio; que no conocía otro cuerpo que tuviese dominio sobre los montes sino el Ayuntamiento, por lo que no asistiría a junta alguna. Le sorprendió, y no pudo menos para instaurar el competente recurso a dicho superior tribunal que pedir al escribano Vázquez le diese certificado de las órdenes que había dado el señor personero al amanuense que se han mencionado; pero habiéndosele negado el escribano a dar 
dicha certificación, lo hace presente a esta Junta para que, como principal interesado en el agravio que le ha hecho el personero, acuerde lo que tenga por más conveniente.

Vista por la Junta la propuesta que antecede, acordó que el presente escribano, respecto a estar aún dentro de las 24 horas, certifique lo que pasó con apercibimiento de darse parte a dicho superior tribunal, y con testimonio de la propuesta de D. Isidoro de este acuerdo y del dicho certificado lo pasará todo el señor D. Francisco de la Ysequilla con el correspondiente oficio a la alta consideración del Real acuerdo, a quien suplica esta Junta se digne en desagravio del decoro.

En consecuencia de que el corregidor no ha contestado al oficio que le pasó la Junta en 22 del corriente para que despachase el correspondiente título al nuevo teniente de guarda de la Montaña de Doramas, D. Gregorio Ponce Díaz, que nombró en la que se celebró en 11 del corriente, se repita por esta Junta nuevo oficio haciéndole presente los inconvenientes de no tener guarda dicha Montaña.

D. Isidoro manifestó la copia del oficio que pasó en respuesta a la Real Sociedad Económica de Amigos del País, según el encargo que se le hizo en junta de ayer, y se acordó se copie.

Se vieron dos memoriales: uno de D. Blas Navarro, vecino de la Vega, presentando lista jurada por Gregorio Alvarado para sacar del Pinar cincuenta vigas, cincuenta tosas, ochenta jubrones, ciento sesenta tijeras y doce durmientes para puertas, para la fábrica de una casa; y otro de D. José Lugo, vecino de esta ciudad, con lista jurada por el oficial José Ramón Jiménez, para sacar del Pinar once tosas, once vigas y setenta jubrones para la fábrica de una casa. Se conceden las licencias.

Memorial de José Gil para sacar madera de la Montaña de Doramas o del Pinar para la fábrica de un barco de la costa. Se concede la licencia.

Memorial de D. Esteban de Ycasa para sacar de la Montaña de Doramas dieciséis corzas para la construcción de unos fuertes que tiene que hacer en sus haciendas para arrastrar la piedra para su fábrica. Se concede la licencia.

\section{7 \\ 1790/ Marzo/27. Canaria.}

Junta con asistencia de D. Isidoro Romero y D. Manuel del Río, regidores perpetuos, y D. Francisco de la Ysequilla, diputado del común.

Se vio un memorial de D. Juan Ruiz de Quintana, vecino de esta ciudad, pidiendo sacar del Pinar quinientas tijeras, cuarenta jubrones y cuarenta tosas para fabricar una casa, bodega y granero en Agaete, en la hacienda de D. Pedro Manrrique. Se concede la licencia.

48

1790/Abril/8. Canaria.

Junta con asistencia de D. Isidoro Romero y D. Manuel del Río, regidores perpetuos, y D. Francisco de la Ysequilla, diputado del común. 
D. Isidoro Romero manifestó un auto de la Real Audiencia con fecha de 17 de marzo de este año, expedido con motivo de la consulta que hizo a la Junta la Real Sociedad Económica de Amigos del País con motivo de la conservación y repoblación del Monte Lentiscal y con motivo de la renuncia que en 8 de ese mes hizo el sobre guardia de ese Monte, Antonio Rodríguez, vecino de la Vega; sobre lo cual mandó el tribunal que se mantuviese en dicho empleo de sobreguarda hasta nueva providencia, y que esta junta proponga los medios convenientes para la asignación de su renta y que remitiese a ese tribunal testimonio del oficio respuesta que pasó esta Junta a el de la Real Sociedad Económica de Amigos del País. Y se acordó se saque testimonio del referido oficio con que respondió esta Junta a la Real Sociedad Económica de Amigos del País y se pase a la Real Audiencia con testimonio de este acuerdo. Y se le hace presente a la Audiencia que la Junta considera el arbitrio menos oneroso el del arrendamiento de las tierras baldias que se han de repartir, para de ahí sacar el sueldo del guarda y sobreguarda del Monte Lentiscal y de los demás guardas de la Montaña de Doramas y el Pinar.

Memorial de Francisco del Carmen para sacar del Pinar roda, codaste, cien palos de ligazón, ocho palos de cinta, veinte latas, sobrequilla, sobrecodaste, timón, tajamar, treinta y cinco palos para tablazón y los palos de arboladura para la fábrica de un barco según memoria jurada. Se concede la licencia.

Memorial de Juan Pláceres, vecino de esta ciudad, solicitando sacar del Pinar veinte palos de aposturas dobles, una cinta doble de vuelta, otra doble derecha y siete tosas para tablas, según memoria jurada, para la composición del barco San Jerónimo, propiedad del solicitante. Se concede la licencia.

\section{9}

\section{0/Abril/10. Canaria.}

Junta con asistencia de D. Isidoro Romero y D. Manuel del Río, regidores perpetuos, y D. Francisco de la Ysequilla, diputado del común.

Antonio Rodríguez, sobreguarda en el Monte Lentiscal, presentó cuatro denuncias:

- Una contra Ignacio de Sosa por tres vacas que encontró pastando siendo testigos Agustín Francisco y Luis Vega;

- otra contra tres hijas de Antonio Guerra, vecinas del Fondillo, de esta ciudad, por corte de leña siendo testigo el moro de Juan Lorenzo, vecino de Tafira;

- otra contra Ana Suárez, vecina del Fondillo, por corte de leña siendo testigo el moro de Juan Lorenzo;

- y otra contra D. Fulgencio Arturo por un caballo que echó a pastar en dicho Monte siendo testigos Antonio Lorenzo y Juan Pérez, vecinos de esta ciudad.

Se acordó se pase al corregidor para que les de curso.

D. Isidoro Romero exhibió una carta con fecha de 8 de abril del vicedirector de la Real Sociedad Económica de Amigos del País, D. Luis de la Encina, dirigida a la Junta sobre que esa sociedad está pronta a costear el desbroce y 
poda del Monte Lentiscal por haber llegado la estación propicia, pagando todos los peones que se empleen en ella y diputando al señor D. José Arbonies y demás señores que le acompañaron el año pasado en el cuidado del plantío. También le comunica que no es el ánimo de la Real Sociedad Económica de Amigos del País interesarse por la leña que resulte de la poda, por lo que le pide se sirva diputar algún o algunos sujetos que la extraigan del Monte y la venda con cuyo producto o en parte podrá pagar al guarda. Se acordó se conteste dando las gracias por la generosa oferta que acepta y nombra para la venta de la leña del desbroce a Antonio Rodríguez y Agustín Velázquez, guarda y sobreguarda de ese monte. Y se pase oficio al corregidor para que expida sus órdenes para que no molesten a los arreos que con cédula de D. José Arbonies y D. Pedro Russell conduzcan ramazón del Monte Lentiscal a la ciudad.

Memorial de D. Francisco del Castillo, alférez mayor y regidor perpetuo de esta isla, pidiendo doscientas cargas de leña para el gasto de su casa. Se concede la licencia con tal de que la leña sea de la seca.

Otro memorial de D. Francisco del Castillo, solicitando licencia para sacar de la Montaña de Doramas doscientas latas para el trabajo de las limpias de las salinas que empiezan en el mes que entra. Se concede la licencia.

\section{0}

\section{0/Abril/24. Canaria.}

Junta con asistencia de D. Isidoro Romero y D. Manuel del Río, regidores perpetuos, y D. Francisco de la Ysequilla, diputado del común.

Habiéndose suscitado la duda de si debe presidir la Junta el señor D. Manuel del Río, que es diputado de ella pero regidor más antiguo, o D. Isidoro Romero, que es miembro propietario, se acordó pase oficio D. Francisco de la Ysequilla a la Real Audiencia para que resuelva.

Haviendo reconozido esta Junta, particularmente por medio de algunos indibiduos, los grandes progresos que a producido en el Monte Lentiscal el zelo, esmero y solizitud con que lo [h] a custodiado el sobreguarda nomvrado por la Real Audiencia, Antonio Rodríguez, y reflesionado que él solo es bastante para que se conserve en la misma prosperidad, acordó suprimir la tenencia de guardia que exercita en dicho Monte Agustín Velazquez por nomvramiento que le hizo esta Junta y aprobó el superior tribunal de la Real Audiencia, y reasumirla en el dicho Antonio Rodriguez con el sueldo de cinquenta pesos que está señalado en el arreglo de proprios y arvitrios de esta ysla, y se pase oficio a la Real Audiencia para que lo apruebe. Asimismo, que la Real Audiencia apruebe gratificación de 10 pesos a Nicolás de Castillo, amanuense de la Junta, por su trabajo en la extinción de actas y sacar testimonios y copias de oficios.

Se acuerda se pongan en acta las copias del oficio de respuesta dirigido a la Real Sociedad Económica de Amigos del País fechado el 19 del corriente y el que se le pasó al corregidor.

Memorial de D. José de Lugo, teniente capitán de milicias y vecino de esta ciudad, pidiendo sacar de la Montaña de Doramas quinientas latas para le- 
vantar un parral de sus haciendas. Se le concede licencia para sacar solo trescientas latas, y se entienda de las más bajas y endurecidas, de forma que no sean renuevos y que no pasen de dos años.

\section{1}

\section{0/Mayo/11. Canaria.}

Junta con asistencia de D. Isidoro Romero y D. Manuel del Río, regidores perpetuos, y D. Francisco de la Ysequilla, diputado del común.

Memorial de D. Manuel Padrón Perera, capitán de artillería y regidor perpetuo de esta isla, pidiendo sacar del Pinar veinte vigas, veinte palos cuadrados, sesenta jubrones y soleras para cargar la madera, tal y como consta de una memoria jurada del oficial Juan de Mesa para la obra del hospital.

El sobreguarda Antonio Rodríguez presentó una denuncia contra una hija de Antonio Guerra, vecina del Fondillo, por haber arrancado lentiscos siendo testigos Miguel Espino y Fernando Espino, vecinos de esta ciudad. Se pase al corregidor.

Memorial de D. Pedro Ramos, vecino de esta ciudad, para sacar del Pinar cuarenta soleras, diez jubrones y una cumbrera para la composición de unas casas en la Atalaya. Se concede la licencia.

Memorial del Dr. D. Domingo Naranjo, clérigo presbitero y vecino de esta ciudad, para sacar del Pinar veinte vigas y treinta jubrones para la composición de unas casas en la Vega. Se concede la licencia.

\section{2}

\section{0/Junio/1. Canaria.}

Junta con asistencia de D. Isidoro Romero y D. Manuel del Río, regidores perpetuos, y D. Francisco de la Ysequilla, diputado del común.

D. Manuel del Río hizo presente los siguientes autos de la Real Audiencia expedidos a consultas hechas en junta de 24 de abril pasado:

- Auto del fiscal de 7 de mayo de 1790 señalando no encuentra título ni motivo alguno para separarse del orden de antigüedad en los asientos en la Junta donde no debe reynar el espiritu de presidencia, que es el que muebe tales dudas y dificultades.

- Auto de 11 de mayo de 1790, diciendo que se haga como lo señala el fiscal en su escrito.

- Auto del fiscal de 11 de mayo sobre que no encuentra reparo en juntar los nombramientos de la Real Audiencia y la ciudad en un solo guarda del Monte Lentiscal, por lo que su dictamen es que se apruebe el nombramiento.

- Decreto de 14 de mayo diciendo que se haga como lo señala el fiscal, aprobando el nombramiento.

Y en vista de los autos, se acordó obedecerlos y que presida la Junta durante su interinidad el señor D. Manuel del Río y se haga saber al sobreguarda lo acordado. 
Habiendo reconocido esta Junta que la Montaña de Doramas tiene tres puertas y salidas principales por las cuales se cometen las extracciones más perjudiciales de madera y leña, que son la parte de Teror, la de Arucas y Moya, y la de Guía y Gáldar, y que cada uno de estos tres caminos reales están bastantes distantes entre sí, siendo casi imposible que el teniente de guarda que reside en Teror ni el que reside en Arucas puedan atender con la eficacia que corresponde los perjuicios que se están cometiendo por la parte de Guía, se acordó representarlo a la Real Audiencia suplicándole se digne permitir que esta Junta pueda nombrar un tercer teniente de guarda vecino de aquella villa o de Gáldar y sus cercanías para que cele aquella parte impidiendo el desorden.

Se presentaron cuatro memoriales solicitando licencia para cortar madera:

- Domingo Galdós pretende sacar de la Montaña tres latas dobles, dos mesas dobles y tres quillas para barco de descarga y la madera correspondiente para dicho barco.

- D. Manuel Mújica, vecino de Guía, para sacar de la Montaña doscientas latas y cincuenta horcones con dos corzas para levantar sus parrales.

- D. Juan Rodríguez de la Vega, presbitero, para sacar del Pinar sesenta cargas de madera entre trozos, vigas y jubrones para la fábrica de una casa en la Vega.

Se acordó conceder todas las licencias.

Otro memorial de D. Pedro Ramos para sacar del Monte Lentiscal la tierra que necesita para hacer teja para la fábrica de las casas que tiene en las haciendas de la Atalaya. Se acordó no haber lugar a la saca de tierra en atenzión a que no solo se defrauda los terrenos en perjuicio del replanto y adelantamiento de los árboles y su frondosidad, sino que con dicho pretesto de hir a sacar dicha tierra talarán y destruirán dicho Monte los que entrasen a sacarla, maiormente estando cercanos los hornos de texa que consume mucha leña, pues aunque en la [a]talaya no se encuentre dicha tierra la hay en otras partes donde se está [h]aciendo dicha teja.

Memorial de D. Isidoro Romero para sacar del Pinar de Pajonales, donde dicen Los Llanos, cuarenta tijeras dobles cuadradas de tres varas y tercia de largo, doce de las redondas y tres vigas dobles de siete varas y cuarta cada una para la fábrica de la casa que tiene en Teror. Se concede la licencia.

\section{3}

\section{0/Junio/9. Canaria.}

Junta con asistencia de D. Isidoro Romero y D. Manuel del Río, regidores perpetuos, y D. Francisco de la Ysequilla, diputado del común.

El receptor Fernando de Quintana hizo saber un auto de la Real Audiencia, a resulta del recurso a ese tribunal de D. Pedro Ramos, por haberle denegado la Junta en la antecedente sacar tierra del Monte Lentiscal para hacer teja, en el que manda que la Junta, con dirección de su guarda, señale a esta parte sitio determinado donde haya vena para la saca de tierra que solicita y donde menos perjuicio se siga al monte. $\mathrm{Y}$ en su vista se obedece pero, como ese 
tribunal no conoce los motivos por los que se denegó, acuerda se saque testimonio de ese acuerdo, añadiendo que la Junta entiende que cuando se saca tierra se perjudica la superficie hasta que solo queda la tierra inútil de producir árbol o hierba.

\section{4}

\section{0/Junio/14. Canaria.}

Junta con asistencia de D. Isidoro Romero y D. Manuel del Río, regidores perpetuos, y D. Francisco de la Ysequilla, diputado del común.

El receptor Fernando de Quintana hizo saber un auto de la Real Audiencia de 10 de junio en el que, habiendo visto el testimonio de acuerdo celebrado por la Junta de Montes en el día 9 del corriente relativo al cumplimiento de lo mandado en el mismo por la sala a pedimento de D. Pedro Ramos, dijeron que se cumpla lo mandado en decreto de dia de ayer, señalando sitio para que con intervención del guarda se saque la porción de tierra que necesita para la fábrica. Y en su vista, se acordó obedecer, y se comisiona a D. Manuel del Río para que, pasando a dicho Monte con presencia del guarda, señale el sitio donde menos se haga perjuicio para sacar la tierra. Y para hacer el informe que se pide, haga la Junta de Montes sobre los parajes que fuera del Monte pueden servir para hacer tejas, se haga presente al tribunal, con testimonio de este acuerdo, que D. Francisco de la Ysequilla sabe que hay terreras en La Pardilla, que es realengo, y en El Ejido, también realengo, ambos parajes cerca de Telde, así como en El Gamonal de Valsequillo, en la Vega, junto a la entrada de San José, cerca del Monte; igualmente, en el Barranco de la Angostura y en otros muchos parajes de la Vega y Telde.

Por la urgencia que ha manifestado el amanuense Nicolás del Castillo, se acordó se haga saber al guarda Agustín Velázquez que, bajo el competente exhibo, le entregue 10 pesos que le señaló esta Junta de gratificación y aprobó la Real Audiencia.

\section{5}

\section{0/Junio/17. Canaria.}

Junta con asistencia de D. Isidoro Romero y D. Manuel del Río, regidores perpetuos, y D. Francisco de la Ysequilla, diputado del común.

Antonio Rodríguez, sobreguarda puesto por Real Audiencia en el Monte Lentiscal, presenta dos denuncias: una contra Diego Rabelo por arrancar acebuche nuevo para hacer un garrote con Alonso Rodríguez como testigo; otra contra José Roque Correa por cortar acebuches en paraje vedado siendo testigos Alonso Rodriguez y un hijo de Antonio Rabelo, todos vecinos de esta ciudad. Se pase al corregidor.

D. Manuel del Río hizo presente que, habiendo pasado al Monte con el sobreguarda Antonio Rodríguez y reconocido el terreno, señaló el sitio donde menos perjuicio se siguiese a dicho Monte para que saque tierra D. Pedro Ramos para la fábrica de teja, y reconoció que había muchos árboles inútiles por estar sin ramazón y casi secos en cuyo lugar podría haber otros nuevos frondosos, lo que hace presente a la Junta para que si no tiene inconveniente 
disponga el que se corten. $\mathrm{Y}$ en su vista, se acordó se haga dicho corte como lo presenta, y se pase carta a dicho sobreguarda para que se haga dicho corte y se venda, y de su producto dará cuenta.

Memorial de D. Sebastián González de Ortega, presbítero mayordomo de la fábrica parroquial de Nuestra Señora del Pino en Teror, pidiendo licencia para sacar de la Montaña de Doramas cincuenta pimpollos y doce tosas de madera para la composición de la iglesia parroquial de Teror. Se concede.

\section{6}

\section{0/Julio/3. Canaria.}

Junta con asistencia de D. Isidoro Romero y D. Manuel del Río, regidores perpetuos, y D. Francisco de la Ysequilla, diputado del común.

Memorial de D. ${ }^{a}$ María Lorenza Hidalgo, vecina de esta ciudad, pidiendo licencia para sacar de la Montaña de Doramas la madera que necesita según lista jurada del oficial Blas de Miranda para el barco San Cayetano, que es una lancha, y para los dos barcos de descarga. Se concede con condición que sea de la más vieja inútil que pueda servir para dicha fábrica.

Memorial de fray Juan Antonio Rodríguez, de la orden de predicadores de esta ciudad, pretendiendo como mayordomo de la cofradía del Dulce Nombre de Jesús y como tal obligado a poner cuatro picaderos en la oficina pública de la carnicería, solicitando licencia para poderlos sacar del Monte Lentiscal. Se concede y el sobreguarda entregará a esta parte los cuatro picaderos para los fines expuestos de los acebuches viejos y secos que se han mandado cortar, pagando su corte.

\section{7}

\section{0/Julio/20. Canaria.}

Junta con asistencia de D. Isidoro Romeros y D. Manuel del Río, regidores perpetuos, y D. Francisco de la Ysequilla, diputado del común.

Habiéndose visto la representación de D. José Lugo y Viña solicitando se le permita sacar del Monte Lentiscal las lajas que se necesitaren para la reedificación y argamasado de la acequia real del heredamiento que pasa por dicho Monte para regar el pago de Tafira y esta ciudad; y reconociendo el nulo perjuicio que se sigue a dicho Monte el sacar las lajas y la utilidad del aprovechamiento de dichas aguas que se perdian, se acordó dar la licencia, para lo cual el escribano escriba al sobreguarda para que señale el sitio más cercano y donde menos perjuicio se siga a dicho Monte.

Memorial con su lista a nombre del señor gobernador de las armas D. Cristóbal del Castillo pidiendo licencia para sacar de la Montaña de Doramas veinte vigas, cincuenta jubrones, cien tijeras y dos tosas para umbrales destinado a la fábrica de dos casas en las haciendas que tiene en aquellas cercanías. Se concede. 


\section{8}

\section{0/Agosto/7. Canaria.}

Junta con asistencia de D. Isidoro Romero y D. Manuel del Río, regidores perpetuos, y D. Francisco de la Ysequilla, diputado del común.

Memorial de D. Pedro Acedo, clérigo presbitero, vecino de esta ciudad, pidiendo sacar de la Montaña de Doramas cuarenta tijeras, veinte jubrones, ocho vigas, dos cumbreras y dos pies derechos para la fábrica de una casa que tiene junto a esa montaña. Se concede.

Y que los guardias informen del estado de dicha Montaña, suspendiéndose en el interin otorgar licencias.

\section{9}

\section{0/Agosto/17. Canaria.}

Junta con asistencia de D. Isidoro Romero y D. Manuel del Río, regidores perpetuos, y D. Francisco de la Ysequilla, diputado del común.

El sobreguarda Antonio Rodríguez presentó dos denuncias: una contra Francisco Galván, vecino de la Vega, con Vicente Hernández y Juan Lorenzo, vecinos de esta ciudad, como testigos; y otra contra Miguel Cabrera con Juan Lorenzo y Vicente Hernández, como testigos, por el corte de árboles nuevos. Se pase al corregidor.

\section{0}

\section{0/Agosto/ 19. Canaria.}

Junta con asistencia de D. Isidoro Romero y D. Manuel del Río, regidores perpetuos, y D. Francisco de la Ysequilla, diputado del común.

D. Isidoro Romero presentó un oficio que dirige a esta Junta el cuerpo patriótico de esta ciudad por medio de su vicecensor, el coronel D. José de la Rocha, fechado el 18 de agosto de este año, que dice lo siguiente:

En Junta celebrada el lunes 17 del corriente se hizo presente a esta Real Sociedad que el guarda del Lentiscal Antonio Rodríguez había conseguido aprehender con el robo en las manos a dos hombres que talaron y cortaron hasta cincuenta acebuches nuevos que este cuerpo ha hecho podar y limpiar a su costa, y que, habiendo embargado los cincuenta horcones que formaron de los acebuches que destruyeron, vino a formalizar su denuncia en los términos prevenidos por la instrucción de la Junta de Montes. Viene a pedir que haga llegar adelante la denuncia del guarda a fin de que sirva de escarmiento ejemplar. Además, la Real Sociedad Económica de Amigos del País se ha enterado que se están cortando y vendiendo algunos acebuches viejos cuya disposición ya fue reclamada en representación de 7 de julio del año pasado a la Real Audiencia por considerar que tales ventas son perjudiciales al Monte, porque sirven de capa al corte de más número que se contrata y vende, y el rajarlos dentro del Monte es mal ejemplar en tiempo que está cerrado. Igualmente ha entendido la Sociedad que con motivo de las comedias que en cada año se representan en los pueblos de Guia y Gáldar en las festividades los dias veinte $y$ cinco de julio y quinze de agosto se hazen unos crezidos cortes de pinpollos, latas, rama y leña en la Montaña de Doramas, y que esta madera, 
que custodiada como está mandado por la Real Audiencia, podría servir de un año para otro por espacio de muchos se vende y destruye en cada año, con lo que al siguiente se repite el corte y tala en perjuicio de la Montaña. Por tanto, la Real Sociedad Económica acordó pedir promover el curso de la denuncia y que estas sigan sin el menor retraso; que suspenda la orden de cortar y vender acebuches viejos conforme lo resuelto por la Real Audiencia; y que disponga el modo con que los pueblos de Guía y Gáldar entiendan y procedan en el conocimiento de que han de custodiar y conservar los pimpollos y latas que han cortado en este año, y los siguientes moderar y arreglar el corte de rama y leña.

No hay respuesta, pero se admite que tienen razón y se acuerda se saque testimonio y se pase a la Real Audiencia para que se digne dar la providencia que sea de su agrado.

\section{1}

\section{0/Septiembre/3. Canaria.}

Junta con asistencia de D. Isidoro Romero y D. Manuel del Río, regidores perpetuos, y D. Francisco de la Ysequilla, diputado del común.

Se vio un testimonio de un oficio remitido a la Real Sociedad Económica de Amigos del País contestando sobre la carta que remitió dicho real cuerpo a esta Junta de Montes.

Muy señor mio: La Junta Munizipal de Montes [de] esta ysla, en la que celebró el día de ayer se enteró del oficio que vuestra señoría le dirigió por mi mano con fecha de diez y ocho del corriente por acuerdo del real cuerpo patriótico de diez y seis del mismo; $y$ con reflexsión a su contenido me ha encargado dé por respuesta para que vuestra señoría se sirva trasladarlo a noticia del expresado real cuerpo que, por lo mismo que conoze de quanto interés espera la conservación de los montes el no retardar un punto la execución de las penas impuestas a los que se a aprehenden talando o haciendo otros perjuicios en ellos, no a omitido tiempo para dar el más pronto expediente en la parte que le toca a quantas denuncias se le han presentado //225vto por los guardas, asi del Lentiscal como demás montes, a fin de que no se retardarse el castigo de los culpados, sirviendo de exemplar a otros para contenerlos. Pero como la ocasión y execución después de acto perteneze al señor corregidor, quien es tan amante del bien público, no a fundado recelo de que la innacción que se a advertido en la punidad de los aprehendidos a tenido origen en dicho señor; antes, por el contrario, cree provenir de omisión en los escribanos a quienes se a encargado pasarlas al señor corregidor. Como quiera que sea, a las denuncias no se les a dado curso. Y esto, con el resiente exemplar del destrozo que se acava de hazer según el aviso de vuestra señoría y de la denuncia que ya se a pasado, comprueba quán poco temor y respecto se tiene a las providencias que se han dado para //226rto la conservación de tan vello Monte por la morosidad y tardo curso del castigo. Lo qual, exigido una seria providencia que ataje en lo sucesivo tales desórdenes, como igualmente el que se advierte cometer algunos vezinos de Guia, con motivo de las enrramadas para las comedias que anualmente hacen representar, en la Montaña de Oramas, sacando de ella espóticamente rama, soleras y latas sin preceder lizencia de la Junta, esta no [h]a contemplado más 
pronto remedio que el de haver acordado la pena de responsavilidad y daños a los escribanos que no actiben el curso de las denuncias que les pasare la Junta, y la misma a los guardas de la Montaña de Oramas (a quienes se les ha escrito ya) que no permitan y que denuncien a los vezinos de Guía, Gáldar, etc., que no saquen de dicha Montaña rama, latas, etc., //226vto con pretesto alguno sin lizencia de la Junta. Y para que dichas providencias tengan toda su fuerza y vigor se acordó dar cuenta al superior tribunal de la Real Audiencia con testimonio deste acuerdo y del oficio de dicha Real Sociedad, suplicándola se sirva aprovar la propuesta que le tiene echa la Junta de nomvrar por la parte de Guia un guarda que sele aquellos términos por no poderlo hacer cómodamente el de la parte de Teror y Arucas y sobreguarda de dicho tribunal por vivir distantes a este otro lado; y finalmente, acordó el que se suspenda por haora el corte de los asebuches viejos atento a los daños que se sirve vuestra señoria ynsigniar se siguirá al arbolado nuebo al tiempo de trasportar los de dicho Monte o enteros o en pedasos. Nuestro Señor guarde a vuestra señoría los muchos años que //227rto deseo. Ciudad real de Las Palmas, ysla de [roto] Canaria, a veinte de agosto de mil setecientos y noventa. Beso las manos de vuestra señoría. Su mayor servidor. Don Ysidoro Romero y Ceballos. Señor vice sensor, coronel don Josef de la Rocha".

Memorial de D. Roque de Torres, vecino de esta ciudad, para sacar del Pinar la madera que consta en memoria jurada del oficial de ribera Blas de Miranda, y también para la fábrica de su casa con memoria de Juan de Mesa, carpintero, que sería roda, codaste, aletas, yugo, sobrequilla, trancaniles, seis palos, cuatro cintas, veinte latas, cien palos de ligazón, dieciséis docenas de tablas, dos costones, cuarenta tosas cien jubrones y sesenta vigas para componer tanto los barcos de la costa de África como para fábrica de su casa. Se concede la licencia.

Entró Fernando de Quintana, receptor de la Real Audiencia, e hizo saber dos autos del tribunal:

- Auto de 3 de septiembre en el que, habiendo visto las denuncias dadas por el guarda Antonio Rodríguez de diferentes daños causados en el Monte Lentiscal, dijeron que, poniéndose a lista de todas las denuncias de que se ha dado cuenta, se devuelvan al corregidor para que las sustancie y determine, y que la Junta de Montes remita certificación mañana día 4 de todas las denuncias que haya pasado al dicho corregidor desde principios de enero de este año.

- Auto de 2 de septiembre en el que, habiendo visto el expediente promovido por la representación de la Junta de Montes sobre que se nombre un guarda más para el celo de la Montaña de Doramas por la parte de la jurisdicción de Guía con el testimonio del oficio que le pasó a la Real Sociedad Económica de Amigos del País y lo expuesto por el fiscal en su escrito de 23 de julio pasado, dijeron que la Junta proceda inmediatamente al nombramiento del nuevo guarda con la misma dotación que los otros, que se abstenga de llamarlos tenientes de guarda y remita a cada uno de ellos testimonio del reglamento, adición y respuestas fiscales y autos que le componen para que se instruyan del modo y forma con que deban proceder contra los taladores. 
Se acordó obedecerlo y que se saque por el presente escribano certificación con nota de todas las denuncias que se han presentado a esta Junta desde principios de enero de este año y lo entregue a primera audiencia en el día de mañana. Y en cuanto a la segunda, se nombra al teniente capitán D. Diego Quintana Pino, vecino de Gáldar, y que el presente escribano le pase carta de aviso después de su aprobación por la Real Audiencia para que haga juramento de fidelidad y obtener su título.

Se vieron los informes que mandaron dar a los guardas de la Montaña de Doramas, y que son los siguientes:

- En Teror, en 25 de agosto de 1790, habiendo visto la carta solicitando informe el estado de la Montaña se halla muy adelantada por lo que hase a los árboles nuevos que [h]an retoñado, y por lo que hazen a los árboles viejos se halla atrasada con el motivo de los cortes de madera para los barcos. Como hasimismo en dicha carta me dize dicho Ayuntamiento no permita que de ningún modo los vezinos de Guía sin expresa lizencia de la Junta saquen latas, ramasón, soleras ni ninguna otra cosa de maderas que no sea leña seca, y habiéndose serciorado y hasiendo las diligencias posibles de dicho corte de latas, ramasón y otras cosas para poder ynformar a dicho Ayuntamiento la serteza, me [he] inteligenciado de Don Francisco Thomás Hernández, guarda nomvrado por la Real Audiencia, de que el corte que havian [h]echo de Guia le habian presentado lizencia conpetente del Ayuntamiento, la que dise sacaron el dia primero de Julio y dize la conserva dicho guarda en su poder, la que presentará a la [h]ora que se la pidan [...]. Francisco Dominguez Falcón.

- Informe de 25 de agosto desde Guía de Francisco Tomás Hernández, sin reseñar nada apreciable.

\section{2}

\section{0/Octubre/2. Canaria.}

Junta con asistencia de D. Isidoro Romero, regidor perpetuo, y D. Francisco de la Ysequilla, diputado del común.

Habiendo tomado la Junta informes exactos y verídicos en orden a la persona que mejor podrá ejercer el cargo de guarda de la Montaña de Doramas por la parte de Guía, se ha acordado proponer a la Real Audiencia por segundo propuesto a José Almeida, vecino de Guía donde dicen Tamaragáldar, atento a la situación en que tiene su casa tan vecina a la Montaña y a los créditos de honradez y buenos procedimientos, a fin de que dicho tribunal se digne confirmar de los propuestos el que fuese más de su agrado, para que se proporcione quien impida los desórdenes de talas que por esa parte se están haciendo.

Memorial de D. ${ }^{a}$ María Ramos y Palencia, señalando que siendo poseedora de una hacienda de viña con casa y bodega en el pago de La Atalaya,. lindando con el Monte donde dicen El Raso, experimenta perjuicio con la novedad de haver [h]allado que, de poco tiempo a esta parte, se ha plantado una cerca de pitas ocupando un pedaso de tierra junto al camino que va de la parte superior de dicho Raso [h]acia la vista del barranco de las Goteras, extrechándolo contra la dicha mi hjacienda y causándome yncomodidad y perjuicios que de dia en dia se aumentarán, extendiéndose y multiplicándose las pitas, en cuia atención y 
para el devido remedio a vuestra señoría, como a quien compete el gobierno y concervación de los montes, ocurro suplicando se sirva mandar reconocer la dicha cerca, y hallando que está en terreno del Monte proveer que se quite y restituir todo al ser y estado que tenia antes de dicho plantio de pitas. Se acordó informe el guarda del Monte Lentiscal.

\section{3}

1790/Octubre/23. Canaria.

Junta con asistencia de D. Isidoro Romero, regidor perpetuo, y D. Francisco de la Ysequilla, diputado del común.

Fernando de Quintana, receptor de la Real Audiencia, hizo saber un auto de ese tribunal, fechado en 19 de octubre de 1790 en el que, habiendo visto el expediente promovido por la Junta de Montes sobre que se nombre un guarda más para celo de la Montaña de Doramas y proponiendo persona para ello, dijeron que se halle por nombrado guarda de la Montaña de Doramas en la parte de Guía a D. Diego Pino de Quintana, vecino de Gáldar, y que observe el reglamento. Se obedece y se acuerda que el escribano escriba al susodicho para que se presente en esta ciudad a prestar el juramento y sacar el título correspondiente.

Se vio el informe de 14 de octubre de Antonio Rodríguez, guarda del Monte Lentiscal, que se le mandó en la Junta antecedente a consecuencia del memorial de D. ${ }^{a}$ María Ramos y Palencia, y dice que conoce el terreno desde que tiene uso de razón y es constante a los vecinos de su inmediación, y que la cerca la ha ejecutado el presbítero D. Pedro Azedo en terreno de dicho monte. Se acordó pase al corregidor para que le dé expediente.

El sobreguarda de la Montaña de Doramas puesto por la Real Audiencia, D. Francisco Tomás de Guzmán, presentó una denuncia en que manifiesta que los vecinos de Guía, en sus medianias, se habian introducido a laborear parte de los terrenos de dicha montaña mirando a dicha jurisdicción, y con esa noticia pasó a ella, y habiendo encontrado a éstos les amonestó suspendieran dicha agricultura por los perjuicios notorios que se seguían; pero no habiendo hecho aprecio de sus consejos siempre, están siguiendo con su intento de forma que llevan asolada dicha montaña. Se acordó pase la denuncia al corregidor.

Memorial de D. Francisco Hernández Guzmán, vecino de Arucas en la costa de Layraga, para sacar de la Montaña de Doramas trescientos horcones y trescientas latas para componer los parrales y demás árboles que tienen en sus haciendas. Se concede con tal que se da comisión al guarda D. Francisco Domínguez y Naranjo, vecino de Teror, para la asistencia de ese corte.

\section{4}

\section{0/Noviembre/5. Canaria.}

Junta con asistencia de D. Isidoro Romero, regidor perpetuo, por estar los demás señores en el campo, atento a la urgencia que había de dar cursos a unas denuncias. 
El sobreguarda puesto por la Real Audiencia en el Monte Lentiscal, Antonio Rodríguez, presentó siete denuncias:

- Contra Sebastián Sosa, vecino de esta ciudad en el pago del Fondillo, porque tiene usurpado al Monte dos fanegadas de tierras más o menos.

- Contra Miguel Guerra, vecino de la Vega en la salida del Monte, porque tiene usurpado fanegada y media de tierra en el pago de San José.

- Contra Agustín Francisco, vecino de la Vega en La Atalaya, por haber usurpado un pedazo de tierra en la Montañeta de la Cruz, lindando con el vaso.

- Contra José Marrero, vecino de esta ciudad, por tener usurpado a dicho Monte una fanegada de tierra que ha agregado a cierta data que obtuvo.

- Contra Juan Hernández, vecino de la Vega en la Atalaya, por tener usurpada una fanega de tierra más o menos.

- Contra Sebastián Miguel, vecino de esta ciudad en el Fondillo, por usurpar dos fanegadas de tierra de ese Monte en el Lomo del Capón.

- Contra Agustín Fernando, vecino de esta ciudad en las cuevas del Sacramento, al que halló en el Monte cortando leña y le quitó el calabozo.

Se acordó pasen al corregidor para que dé en ellas las providencias oportunas.

Se vio una representación del sobreguarda puesto por la Real Audiencia en el Monte Lentiscal, Antonio Rodríguez, en el que dice que los sacadores de varro para la fábrica de loza basta de La Atalaya y cuevas de ella executan las excabaciones con grave perjuicio de los árboles y a el camino a que se aproximan, porque lo uno dañan las raízes de los árboles y lo otro arruinan //239vto el camino, perdiendo y secando dichos árboles y maleando o inutilisando el paso de los tránsitos precisos. $Y$ aunque varias veces ha reconvenido y mandado a algunos de los que se entretienen en sacar dicho barro que lo executen en otros paraxes en que no se acerquen ni dañen a los azebuches ni a los caminos, no han querido desistir de su voluntario empeño de hacerlo en los sitios en que se nota el perjuicio y daños, como lo acredita la diligencia que ha practicado el exponente con tres testigos, que fueron Agustín Francisco, Josef de Ávila y Josef Pérez, reconoziendo nueve Azebuches grandes que van perdidos en la Montaneta de los Negros a causa de haverles socabado y cortado las raizes, y asimismo el camino que por //240rto dicha montañeta sube al vaso, en el cual han hecho bastante daño con sus excabasiones. Y para que estos daños no continúen a título de ser beneficio público el de la fábrica de loza tosca para que sesara el barro de dichos parajes, supuesto que se puede sacar de otros sitios sin causar tales perjuicios, vuestra señoria se ha de servir dar las providencias que estime por más conveniente con sus órdenes e instruciones al guarda que expone para lo que debe executar con los rebeldes, asi para lo sucesivo como para lo ya efectuado. Ciudad de Canaria, y octubre, treinta de mil setecientos $y$ noventa años. Y en su vista, se acordó prohibir la saca de tierra en el paraje y sitios que expresa el guarda y se haga saber al mismo por el escribano señale a los vecinos de La Atalaya el paraje que le parece en que menos prejuicio haya, y advertidos por el guarda denunciará al que contraviniere. 


\section{5}

\section{0/Noviembre/10. Canaria.}

Junta con asistencia de D. Isidoro Romero, regidor perpetuo, y D. Francisco de la Ysequilla, diputado del común.

El sobreguarda puesto por la Real Audiencia en el Monte Lentiscal, Antonio Rodríguez, presentó dos denuncias:

- La primera contra Domingo Rivero, vecino de la Vega en el pago de La Atalaya, por haberlo encontrado cortando cabos y latas.

- La segunda contra Ignacio de Sosa, vecino de esta ciudad en el Fondillo, por encontrar a un hijo suyo apastando a un burro, el cual lo mandó a la carnicería.

Se acordó suplicar al señor corregidor se les dé pronto expediente.

\section{6}

\section{0/Diciembre/1. Canaria.}

Junta con asistencia de D. Isidoro Romero y D. Manuel del Río, regidores perpetuos.

El sobreguarda puesto por la Real Audiencia en el Monte Lentiscal, Antonio Rodríguez, presentó ocho denuncias:

- Contra D. Bartolomé Bravo, vecino de esta ciudad, por tener usurpado en el Monte un pedazo de tierra en el Pago de Zumacal.

- Contra D. Miguel Manzano, vecino de esta ciudad, por tener usurpado en el Monte y agregado a su hacienda un trozo de tierra en San José, a la salida de él.

- Contra D. Francisco del Castillo Ruiz de Vergara, por tener agregado a sus terrenos un pedazo de monte en el pago de El Zumacal.

- Contra D. Domingo Naranjo por tener usurpado en el pago del Colegio un trozo de monte que ha agregado a su terreno.

- Contra Juan Peñate por tener agregado a su terreno un pedazo de monte en el Pago de San José y salida del Monte.

- Contra D. Pedro Azedo, clérigo presbítero y vecino de esta ciudad, por usurpar del Monte dos pedazos de tierra que ha ido a terrenos suyos, uno donde dicen la Joya del Alcalde y otro donde llaman El Vaso, cercado de pitas.

- Contra Juan Pérez, vecino de esta ciudad, en unión de sus medianeros tiene usurpadas de dicho Monte un trozo de tierra en la Data del Marqués a que ha agregado tierras suyas.

- Contra D. Fulgencio Arturo por haber encontrado un caballo haciendo daño en el Monte.

Se acordó suplicar al corregidor les dé pronto expediente. 
El sobreguarda del Monte Lentiscal hace presente los perjuicios que se han conseguido al Monte de permitir el recogimiento de vaga de lentisco por los muchos que de estos han despimpollado, de que precisamente se les ha de seguir atraso en su adelantamiento, y se acordó se haga saber a dicho guarda que, por ahora y hasta nueva orden de la Junta, no permita entrar a dicho Monte a persona alguna a tomar vaga.

El escribano D. Francisco Martínez de Escobar exhibió catorce denuncias: contra Felipe Bailón; el mozo de Sebastián Miguel; Pedro Mújica; Antonio González, de Telde; Juan Ramos, de Telde; Catalina, mujer de Tomás Vera, vecina de esta ciudad; José Roque Correa; Diego Rabelo; Antonio Guerra, de esta ciudad; Ana Suárez; los hijos de Agustín Fernando; José González; un fulano Martel, de Jinámar; Ignacio de Sosa; Ana Suárez, duplicada; el mozo de Sebastián Miguel, duplicada; y Antonio Guerra, duplicada. A las que están dando curso y concluidas, en las cuales hay dos insolventes y enfermos y tres por duplicadas a las que no se ha dado curso, y se ha dado cuenta de ellas a la Real Audiencia en 3 de septiembre de este año, y que tiene exhibidas el presente escribano desde 15 de noviembre. Se acordó vuelvan al escribano con nota de quedar la Junta enterada.

Reconoziendo la Junta con sumo dolor el destrozo y tala tan general que se ba [h]asiendo en los Pinales y demás montes de la otra parte de las cumvres $y$ estracción de maderas fuera de esta ysla por no haver en esta ciudad un guarda o persona encargada de impesionar e inquerir si las que se desemvarcan en esta ciudad y se estraen de ella fuera de la ysla se executa con la competente lizencia de la Junta, acordó nombrar por tal guarda en esta ciudad, atento a serlo actualmente de la orchilla y a su homvria de bien, a Nicolás del Castillo, vezino de esta ciudad, para que reconozca si las maderas que se desenvarcan han sido cortadas con anue[n]cia de esta Junta; y lo mismo la leña de sabinas se trae de las calmas, cuia espezie se va [h]asiendo tan rara por la absoluta libertad de cortar, que dentro de poco tiempo no habrá en aquellas partes ni un árbol de que poder aprovecharse los vesinos de la ysla. Y para precaver la extracción de leña de la Montaña de Doramas por el puerto de Gáldar a la isla de Tenerife, se haga saber a los guardas de dicha Montaña denuncien a cualesquier personas que la embarcare sin licencia de esta Junta, so pena de responsabilidad. Y para que pueda tener efecto se pase testimonio de él a la Real Audiencia, a quien se suplica se digne aprobar este acuerdo en atención al beneficio que se seguirá de él. Y como la isla tiene privilegio de Su Majestad para imponer derechos a la madera que se extraiga para las demás se ponga corriente para que su producto sirva para ayuda de fondos de esta Junta y pagar a los guardas y gastos de replantos que se ofrezcan.

\section{7}

\section{$1791 /$ Enero/7. Canaria.}

Junta con asistencia de D. Isidoro Romero y D. Manuel del Río, regidores perpetuos.

El sobreguarda puesto por la Real Audiencia en el Monte Lentiscal, Antonio Rodríguez, presentó tres denuncias: 
- Contra Josefa Guerra, mujer de Francisco Candelaria, por arrancar lentiscos. Fueron testigos José Pérez y Miguel Espino, vecinos de la Vega, y se hallan viviendo en el Castillejo.

- Contra la hija, llamada Francisca Hernández, y Fernando Gaspar, vecinos de Telde en el pago de la Matanza.

- Contra Tomás el Obispo, vecino de Telde en La Matanza, cogiendo hierba.

Y se acordó se pasen al corregidor para que se sirva darles despacho.

\section{8}

\section{1/Enero/10. Canaria.}

Junta con asistencia de D. Isidoro Romero y Zevallos, regidor perpetuo.

Memorial de D. Gregorio Henriquez, presbítero, vecino de esta ciudad, pretendiendo sacar de la Montaña de Doramas tres mil latas y horcones y madera necesaria para un hagar ${ }^{12}$ para la reedificación de una viña que tiene en Arucas. Se acordó concederle licencia sólo para seiscientas latas y la madera para el agar y sea con intervención de los guardas de dicha Montaña.

El señor D. Isidoro Romero, que fue el único que asistió por no haber nombrado diputado y estar desazonado el señor D. Manuel del Río dijo que, habiendo pasado ya mucho tiempo que se le pasó aviso para que viniese a hacer el juramento de estilo a D. Diego Pino de Quintana, vecino de Gáldar, a quien esta Junta había nombrado guarda por la parte de Guía, aprobada por la Real Audiencia y que hasta ahora no se ha presentado en esta ciudad al paso que en la dicha Montaña por la parte de dicho Guia se están hasiendo grandes destrozos, es de parecer nomvrar en lugar de dicho Pino a Juan Martín Custodio, vezino de la villa de Gáldar. Y para que se verifique, se saque el testimonio de este acuerdo y se entregue a la Real Audiencia.

No habiendo cumplido los guardas del Monte Lentiscal, Agustín Velázquez y Antonio Rodríguez, con dar la cuenta que se les tiene mandado exhibir del importe de la leña del desbroce y demás árboles que se cayeron en el dicho Monte y mandaron cortar, el presente escribano les haga saber que en cuatro dias la exhiban, con apercibimiento que, de no cumplir, se dará parte a la Real Audiencia para que provea lo que convenga.

\section{9}

\section{1/Enero/17. Canaria.}

Junta con asistencia de D. Isidoro Romero, regidor perpetuo, por no haber nombrado diputado y estar desazonado el señor D. Manuel del Río.

Acordó la Junta que el testimonio de acuerdo donde se nombra guarda de la Montaña de Doramas por Guía a Juan Martín Custodio, vecino de Gáldar, se acordó pasar a la Real Audiencia para su aprobación, y se remita con oficio por D. Isidoro Romero incluyendo la carta de D. Diego Quintana Pino, a quien antes se habia nombrado y aprobado por ese tribunal, a quien se haga presente que este se halla imposibilitado por habérsele nombrado alcalde actual de Gáldar.

12 Sic. 
Viendo la Junta que hace tiempo que no se presenta persona alguna a sacar licencia, y viendo al mismo tiempo las crecidas partidas que continuamente se están desembarcando por estas playas, necesitada de su celo por la conservación de los montes de la isla, acordó que, sin ser visto hacer instancia sino por un efecto de su patriotismo y obligación, se represente a dicho tribunal que está persuadida de que, si no se nombra guarda en esta ciudad que solicite averiguar con qué licencia se han cortado las maderas que aportan, se reducirá la Junta a ser no más que una apariencia y los Pinares se destruirán. Además, tiene entendida la Junta que se ha abierto un camino nuevo en los Pinares que conduce al puerto de la Aldea, por donde clandestinamente y del modo más fácil van a destruir los Pinares, porque por allí la están conduciendo al puerto de Santa Cruz para tantas casas que hay que reedificar que destruyó el incendio, al paso que los grandes montes de aquella isla se conservan con ruina inevitable de los de esta pobre isla, que de aquí a poco tiempo no tendrá madera para sus propias fábricas, lo que solo se podrá remediar si la superior autoridad del acuerdo se digna librar su provisión al alcalde de La Aldea para que mande cerrar dicho camino y no permita que se embarque madera por dicho puerto. Se pase testimonio a la Real Audiencia y oficio al guarda del Pinar para que con la mayor brevedad se presente a esta Junta.

D. Isidoro Romero pidió licencia para sacar de la Montaña de Doramas dos vigas de til que necesita para una prensa. Se concede la licencia.

\section{0 \\ 1791/Enero/21. Canaria.}

Junta con asistencia de D. Isidoro Romero y D. Manuel del Río, regidores perpetuos, y D. Sebastián de Quintana, sindico personero.

Se vio el decreto de la Real Audiencia de 19 del corriente, que se expidió con motivo de los dos acuerdos de la Junta de 10 y 17 de enero, relativo a nombrar por guarda de la Montaña de Doramas a Juan Martín Custodio, vecino de Gáldar, en lugar de D. Diego Quintana Pino por no haber parecido este a juramentarse a pesar de habérsele pasado aviso; y el segundo, a solicitar permiso de poder nombrar guarda en esta ciudad que solicitase saber las licencias con que se han cortado las maderas que aportan en estas playas y que se librase provisión por la Real Audiencia al alcalde de La Aldea para que no permita se embarquen maderas por aquel puerto. Y siendo el contenido del auto el que se convocase la Junta plena con asistencia del personero y su escribano para saber si esta es del mismo dictamen, que no puede ser válida con un solo sujeto; y habiéndose juntado todos los que hay e informada del contenido de los acuerdos, acordó que es del mismo dictamen y cree muy urgente se nombre dicho guarda en la parte de Guía y el que se pide para esta ciudad, y asimismo que se libre la provisión al alcalde de La Aldea para que impida el embarque y saca de maderas.

Se acuerda aprobar la licencia que pidió D. Isidoro Romero para sacar dos vigas de la Montaña de Doramas. 
71

1791/Enero/25. Canaria.

Junta con asistencia de D. Isidoro Romero y D. Manuel del Río, regidores perpetuos, y D. Sebastián de Quintana, síndico personero.

Fernando de Quintana, receptor de la Real Audiencia, hizo saber un auto de ese tribunal con fecha de 22 de enero de 1791 en el que, visto lo acordado en la Junta de Montes de 21 del corriente relativo a nombramiento de guarda de la Montaña de Doramas en Juan Martín Custodio, vecino de Gáldar, y el que se solicita para la ciudad para la averiguación de la madera y leña que se desembarca, dijeron que se aprueba dicho nombramiento de guarda en Juan Martín Custodio de la Montaña de Doramas por la parte que linda por Guía, lo cual se haga saber al susodicho para su aceptación y juramento; y en lo que respecta al guarda de esta ciudad, pase a la Junta de la Sociedad para que exponga sobre ello lo que se ofreciere. Y en su vista, se acordó que el escribano pase aviso a Juan Martín Custodio para que se presente en esta ciudad para hacer el juramento.

\section{2}

\section{1/Febrero/1. Canaria.}

Junta con asistencia de D. Isidoro Romero y D. Manuel del Río, regidores perpetuos.

En esta Junta, a la que no asistió el personero por estar ausente en Teror, se vio la cuenta que dio el guarda del Monte Lentiscal, Antonio Rodríguez, del importe de la leña del desbroce que se hizo el año pasado y que se le mandó exhibir en esta Junta, y que es del tenor siguiente:

Del desbroce se cobró Antonio Rodríguez de los acebuches vendidos:

Agustín Romero, 15 pesos de 15 troncos: 150 reales.

El cura de la Vega, 10 pesos de 10 troncos: 100 reales.

D. Bartolomé Bravo, 10 pesos de 10 troncos: 100 reales.

D. José González, 5 pesos de 5 troncos: 50 reales.

D. Carlos Navarro, 5 pesos de 5 troncos: 50 reales.

El sacristán de la Vega, 2 pesos de 2 troncos: 20 reales.

José Hernández, peso y medio de 1 tronco: 15 reales.

Que todo importa 73 pesos y 12 cuartos corrientes.

Y en su vista, se acordó se tenga presente para la primera Junta. Y respecto a que Agustín Velázquez, guarda que fue del Monte Lentiscal, no ha exhibido la cuenta, se acordó que el escribano le haga saber que en el término de tres dias la exhiba bajo apercibimiento que corresponda. \Hice saber hoy 8 de Febrero a Agustín Velázquez/.

Memorial de D. José Tovar, clérigo presbitero, vecino de Gáldar, pidiendo licencia para sacar de la Montaña de Doramas doscientos horcones para su parral. Se concede la licencia. 


\section{3}

\section{1/Febrero/8. Canaria.}

Junta con asistencia de D. Isidoro Romero y D. Manuel del Río, regidores perpetuos, y D. Sebastián de Quintana, síndico personero.

D. Isidoro Romero exhibió un auto y dos decretos de la Real Audiencia, que le entregó e hizo saber el escribano de cámara D. José Pérez, y que son los siguientes:

- Auto de 4 de Febrero de 1791 en el que, habiendo visto el acuerdo de la Junta de Montes de 17 de enero pasado relativo a atajar el gran destrozo que se comete en los pinares y saca de maderas que se están haciendo por el puerto de La Aldea para llevar al puerto de Santa Cruz de Tenerife, y lo expuesto por la Real Sociedad Económica de Amigos del País en 31 del mismo, dijeron que la Junta de Montes, con anuencia de la Real Sociedad, acuerde el sitio o sitios que estime por conveniente deber acotarse en los Pinares, y los personeros respectivos colindantes de los Montes den irremisiblemente cuenta a la Junta cuenta de los desórdenes que advierten, como también la noticia mensual de los cortes que propone la Real Sociedad .

- Decreto de la Real Audiencia en el que, como consecuencia del escrito fechado en Canaria en 8 de Febrero de 1791 de D. Francisco Tomás Hernández, vecino de Arucas y sobreguarda de la Montaña de Doramas, diciendo que el sin número de carboneros que de ordinario concurren a dicha Montaña es la causa de que sus árboles no permanescan, en tal conformidad que de no ponerse remedio en ello llegará día que no se verifique la espesura de estos, pues aunque es cierto que dicha fábrica de carbón es útil a los rep[úbli]cos de esta ysla, se entiende que sea de aquellos árboles que por su vejez ya no se espera provecho alguno sino el que se reduzcan a hacerlos carbón, para lo qual es preciso que haya número señalado para que no se experimente que se lleben [h]a hecho su arboleda, y para que por la sala se dé la providencia más conforme a equidad y justicia, ordena que se lleve a la Junta de Montes, quien lo pase a la Real Sociedad Económica de Amigos del País y, con lo que esta exponga, acuerde lo que tenga por conveniente y se ejecute inmediatamente.

- Acuerdo de 27 de enero de 1791 por el que aprueba los nombramientos de diputados que faltaban en la Junta de Montes hechos por la ciudad en cabildo celebrado en 24 de enero, y que recaen en D. Ignacio Díaz y D. Andrés Barreto y comunicado por carta de 26 de enero del mismo año.

Habiéndose tratado sobre el auto y decretos antecedentes, se acordó en cuanto al auto y decreto que habla sobre carbón se saque testimonio de ambos y con el oficio competente se pase a la Real Sociedad Económica de Amigos del País por D. Isidoro Romero, insinuándole que el guarda de los Pinares, por órdenes anticipadas de la Junta que se le habian dado, ha ofrecido informar dónde podrán hacerse los acotamientos que hace mucho tiempo que la Junta tiene pensado de ser necesario hacerlos para la conservación de dichos montes. Y en cuanto al segundo decreto, se obedece, y que el escribano lo haga saber a los señores diputados nombrados para la concurrencia a esta Junta. 
El escribano da cuenta de haber hecho saber Agustín Velázquez exhibiese la cuenta del desbroce según lo mandado por la Real Audiencia y la exhibió, y es la siguiente:

Cuenta formal que Agustín Velázquez da a la Junta de Montes de la leña del desbroce que se hizo en el Monte Lentiscal y de la que se hizo de unos acebuches viejos, para lo cual se le dio licencia como guarda que fue de dicho Monte.

\section{Cargos:}

Por ocho pesos que importaron ocho acebuches que le vendió a D. Bartolomé Bravo: 64 reales de plata.

Por cuatro acebuches en ocho pesos vendidos a Sebastián de Sosa: 64 reales de plata.

Por cuatro acebuches vendidos a Antonio Rodríguez en 18 de plata: 18 reales de plata.

Por tres pesos de unos troncos de acebuches secos vendidos a Agustín Francisco: 24 reales de plata.

Por dos pesos de otros troncos vendidos a dicho Agustín Francisco: 16 reales de plata.

Por trece pesos menos dos de plata de otros troncos de acebuches secos vendidos a Mateo Cabrera: 102 reales de plata.

Por trece pesos de leña que llevó D. Domingo Galdós: 104 reales de plata.

Por cuatro pesos y ocho cuartos de leña menuda que se vendió, 32 reales de plata y 8 cuartos.

Suman las partidas del cargo: 424 reales de plata y 8 cuartos.

Descargo:

Por diez pesos dados a D. Nicolás del Castillo, mandados dar por esta Junta y aprobación de la Real Audiencia, según consta de recibo: 80 reales de plata.

Por un real de plata a Juan Lorenzo, maestro alguacil de orden del señor D. Isidoro Romero.

Por treinta y ocho reales de plata pagados a los trabajadores en el desbroce de dicho Monte.

Por veintidós de plata gastados de dos fanegas de vaga de acebuche que se mandaron coger.

Por sesenta libras de pan que se gastaron para el replanto de dicho Monte que se compró a María Lorenzo a razón de 4 reales la libra, importa 15 reales de plata.

Por treinta cuartillos de vino comprados a Antonio Rodríguez a razón de quince cuartos, 29 reales de plata.

Por tres de plata de llevar al Monte la vaga que se recogió y se la pusieron en su casa.

Suma el descargo: 188 reales de plata. 
Rebajado el cargo que se hace, resulta que ha de haber 236 reales de plata y 8 cuartos, que hacen 29 pesos y medio y ocho cuartos.

Se acordó se saque testimonio de esta y de la de Antonio Rodríguez, guarda actual del Monte Lentiscal, y se pase a la Real Audiencia con el oficio, suplicándole se sirva acceder a lo solicitado por esta Junta en razón de los 10 pesos para el amanuense Nicolás del Castillo en atención al gran trabajo que tiene en extender las actas, sacar testimonios y escribir oficios, y otros 10 pesos para los escribanos de Cabildo. Y que se mande dar cada año de dicho fondo de los desbroces 5 pesos a un portero para que cite a los señores de la Junta por excusarse estos y por dicha causa no se celebran muchas más actas en los dias señalados. Y que también se sirva señalar lo que de dicho liquido se ha de dar a los dos guardas que no han traído renta, y lo que sobrare declarar donde se ha de depositar.

\section{4}

\section{1/Febrero/10. Canaria.}

Junta con asistencia de D. Isidoro Romero, regidor perpetuo, y D. Ignacio Díaz y D. Andrés Barreto, diputados. No asistió el síndico personero ni D. Manuel del Río, a pesar de ser citados.

Memorial de D. Juan Navarro, vecino de esta ciudad, pretendiendo sacar del Pinar cien jubrones, treinta tosas, veintisiete vigas, cien tijeras, cuatro cumbreras y ciento cuarenta tijerones que necesita para la fábrica de una casa en esta ciudad, según la memoria jurada por el maestro Esteban Pastrana. Se acordó conceder la licencia.

\section{5}

\section{1/Marzo/11. Canaria.}

Junta con asistencia de D. Manuel del Río y D. Isidoro Romero, regidores perpetuos, D. Ignacio Díaz y D. Andrés Barreto, diputados, y D. Sebastián de Quintana, síndico personero.

D. Isidoro Romero presentó la instrucción que se le encargó por esta Junta para la instrucción y mejor desempeño de los encargos de los guardas de los Pinares, Montaña de Doramas, Monte Lentiscal y demás de esta isla que se tratase sustancialmente lo que comprende el nuevo Plan de Gobierno de Montes de esta isla que aprobó la ciudad y tribunal de la Real Audiencia que está a la cabeza de este libro, sus adiciones que están en Junta de 31 de octubre de 1788 y la real cédula de montes de 1748. Y habiendo sido examinada la dicha instrucción y cotejada con lo dispositivo de dichas leyes y ordenanzas citadas y hallarse conforme y en método breve y claro e inteligible, se acordó aprobarlas, se dé testimonio de ella a los guardas y se copie literalmente en esta acta para su mejor conservación.

Ynstrución que presenta el señor don Ysidoro Romero y Ceballos a la Junta para govierno y exacto desempeño de los dos guardas de los Pinares, los tres de la Montaña de Oramas, del sobreguarda puesto por la Real Audiencia y de el que tiene el Monte Lentiscal de esta ysla arreglado a los artículos del nuevo 
Plan de Govierno, sus adiciones y autos posteriores de la Real Audiencia y real cédula del año de mil setecientos quarenta y ocho.

El primero ojecto y cuidado de los guardas ha de ser el celar //260rto los limites, linderos y orillas de los montes denunciando inmediatamente a los vezinos colindantes que usurparen algún terreno, cortaren árbol y biolaren sus barreras so pena en caso de omisión de beinte ducados de multa, privación de oficio y responsavilidad de todos los daños, costas y gastos que se causaren para su restitución $=$

2. . . Han de procurar siempre conservar intactas e ylesas las arboledas y malesas de las orillas de los montes sin permitir cortes en ellas, pues este es el modo de evitar y hacer más conosidas las usurpaciones que se intentaren $y$ tener como bardados los montes, bajo la misma en el caso de contrabención=.

3. ${ }^{\circ}$. A los carboneros, según el párrafo segundo del nuevo plan y primero de sus adiziones, tanto de la Montaña de Oramas como de los Pinales y demás de monte alto del otro lado de las cumvres, no les permitirán por ningún caso los guardas hacer carbón dentro //260vto de los montes sino a las orillas y puestos que se señalaren en parajes que no pueda propagar el fuego a las arboledas $y$ [h]ojarascas, so pena de incurrir en las referidas penas. Y quando acontezca algún incendio casual harán guardar lo que contiene la ley veinte $y$ uno $=t$. $1=$ libro 7 de la Nueva Recopilación, cuias palabras son las siguientes: Porque nos fue fecha relación que en Andaluzia y Extremadura y Reyno de Toledo y otras partes de nuestros Reynos aconteze quemarse algunos montes para más cresimiento de ellos y de pasto, y destas quemas resultan muchos daños, y después de quemado como echan junto al suelo tallos frescos y tiernos los ganados cavrios los comen luego mejor que otro ningún pasto, de que resulta que las ensinas y otros árboles no tornan a lo ser y pierdese la bellota y cría de los puercos, fue //261rto nos pedido que para el remedio mandásemos que cada y quando acaesiere quemarse algún monte dentro de cinco o seis años no entrase en él ningún ganado so grandes penas. Y nos, teniendo considerasión a lo que se nos pide ser justo, mandamos a los del nuestro Consejo den todas las provisiones necesarias paras las justicias de todos los lugares y partes do acaesiere quemarse los montes que no dejen entrar en ellos a paser ningunos ganados hasta que, informados los de nuestro Consejo, provean en ello lo que se deve mandar. $Y$ mandamos a los del nuestro Consejo que entre los otros capitulos de corregidores se les ponga lo contenido en esta ley para que mexor se execute= Esta ley se mandó por el tribunal de Real Audiencia que se insertase en la instruc/cjión de los guardas que está en Junta de ocho //261vto de octubre de mil setecientos ochenta y ocho=.

4. ${ }^{\circ}$. Los guardas, al instante que vean esta ynstruc[c]ión, señalarán dos puestos a los carboneros a las orillas de la Montaña a vastante distancia de las arboledas $y$ otros dos en el pinal donde hagan el carbón, so pena que de no poner en ejecución esta orden serán responsables a todos los daños y se procederá además con todo el rigor de las leyes; y formarán lista de los empleados actualmente en este ejercicio y los citarán para que en dia determinado, lo más vreve que se pueda, comparezcan y se presenten a la Junta para instruirles del modo de hacer el carbón según el uso de Castilla, el qual presisamente se habrá de hacer de breso, y de los retales que sobraren de los cortes de las lizencias, 
//262rto y de ninguna manera de árbol otro alguno, a menos que con intervención del guarda lo fragüen de algún árbol que se haia caído y no sirva por sus retorturas y güecas para pieza útil de edificios o varcos, según el párrafo terzero del nuebo plan y segundo de sus adicciones. Y por este se permite tamvién que con intervención del guarda puedan arrancar y sacar de la Montaña los dichos carboneros todas aquellas zepas viejas de árboles caducos de que ya no se espere probecho de sus renuevos=.

5. . . Se permite a los leñadores que en los sitios que estubiesen vedados $y$ cerrados de dicha Montaña puedan entrar libremente y sacar leña como sea de retales o de gajos secos de aseviño, pero se les prohive rigorosamente el que la [h]agan de árbol ni gajo verde. Y si acaesere no haver ya leña seca en dicha Montaña, en este caso lo parti//262vto ciparán al guarda para que con su intervención se corten todos aquellos gajos y árboles inútiles para edificios y barcos y obras de ensemblado, a fin de que aya provisión de donde los leñadores puedan conduzir el abasto tan necesario de leña a esta capital y demás pueblos de la ysla, bien entendido que dicho corte se ha de ejecutar en el paraje donde aya más espesura y no haya tanto despoblado (según el punto dies de las adiciones) $=$.

6. . . A los árboles que para este efecto o para cumplir alguna lizencia no se cortaren por el pie sino algún gajo se le dejará orca y pendón, advirtiéndose que se a de procurar siempre conservar los dos gajos más rectos, más nuebos y sanos del árbol, según se previene en el párrafo quinto de las adiciones y sesto del nuebo plan //263rto; y para [a]quel tamvién se previene que no se puedan cortar por el pie árboles nuevos, sino los más antiguos y sasonados $=$.

7. . . Los guardas del Pinar, por haora y [h]asta nueva orden, denunciarán a los que cortaren sabinas y Jayas, vien sea para Leña o bien para otro efecto, o qualesquiera otro árbol alto como todos del otro lado de las cumvres, sin que antes haia obtenido lizencia de la Junta, como se manda en el párrafo diez de la adicciones al nuebo plan, y lo mismo y con más rigor se entiende de los Pinos $=$.

8. ${ }^{\circ}$ Los guardas de la Montaña de Oramas no consintirán que para cumplir las lizencias que se dieren para cortar maderas para edificios o barcos se corten sino laureles, asebiños y de ninguna manera tiles, //263vto Jayas, palos blancos, tejos, barbusanos ni biñáticos sin que se conceda expresamente en la lizencia, como lo manda el párrafo doze de las adicciones y terzero del nuevo Plan=.

9. ${ }^{\circ}$ Que los guardas de Pinares, Montaña de Oramas y Monte Lentiscal no puedan llevar más dietas, salarios ni derechos que ocho reales vellón por cada lizencia por señalar el corte que pasare de tres árboles, y de abajo no más que quatro reales vellón; $y$ los mismos quatro reales por cada lizencia cuio corte sea para aperos y demás utensilios de labranza, como son timones, cabezas, arados, Ganvuesas, escaleras, corsas y pariguelas, garrotes y Lansas, según se previene en el auto del superior tribunal de la Real Audiencia de veinte de junio de mil setecientos ochenta y nueve años que está en Junta //264rto de treinta de dicho mes y año. Y lo mismo deven llevar los escribanos de la Junta por cada lizencia con esta misma dicha distinción, y denunciarán a los dichos labradores que sin la dicha lizencia y intervención del guarda se entrometieren a hacer 
cortes para dicho efecto. Y havrán de jurar en los memoriales ser para uso propio y no para vender dejando orca y pendón, según el capitulo diez y ocho de la real cédula de montes y párrafo seis del nuebo plan, según se dispone en el párrafo terzero de dichas adiciones que están en Junta de treinta y uno de octubre de mil setecientos ochenta y ocho. $\backslash Y$ se les pro[h]yve imponer multas, quitar hachas y azadas a los contraventores, si no es el denunciarlos y procesarlos quando huviere motivo/.

10. ${ }^{\circ}$ Que los guardas no consientan que de los árboles o arbustos de follado se haga leña ni carbón, pues se reservan para la provisión de arquería de pipas $y$ abasto de cestas y serones para fábricas y otros usos, según está mandado en las //264vto celebradas en dies y veinte $y$ dos de diziembre del año de mil setecientos ochenta y ocho, y denunciarán a los que haún para estos usos procedieren al corte sin la correspondiente lizencia e intervención del guarda=.

11. . Que los guardas de la Montaña de Oramas, por haora y hasta nueva orden de la Junta, no permitan de ninguna manera (denunciando a los contraventores) hazer rosas ni desbroces en dicha Montaña porque importa se conserve esta malesa, espezialmente en los parages despoblados para criar y preservar su sombra, los arbolitos y retoños nuevos a ecesión, como está dicho, de los helechos y sarsas, que se permite sacarlas en todo tiempo como está mandado en el párrafo segundo de dichas adicciones=.

12. . Los guardas habrán de cobrar del que no pusiese tres árboles nuebos en lugar del que cortare //265rto (aunque tenga lizencia) quatro reales vellón de Castilla por cada uno siendo corpulento, y dos por el menos grueso, no dejando sacar dicha madera cortada de Pinares, Montaña y Monte Lentiscal sin que antes [h]ayan exivido dichos derechos destinados para los replantos y fondo de la Junta, cumpliendo con dichas condiciones según se ordena en el párrafo veinte y dos del nuevo plan y quarto de las adicciones. Y será de su obligación tomar razón del dia, mes y año que se le presentare la lizencia al respaldo de ella y de anotar asimismo en ella el número de árboles que se huviesen cortado para darle su cumplimiento y los dichos guardas poder dar razón cada tres meses a la Junta con esibo de dichas licencias y del dinero que a entrado en su poder, como todo se previene en dicho párrafo veinte $y$ dos del nuevo plan y quarto de las adicciones $=$.

13. ${ }^{\circ}$ Que no permitan //265vto y denuncien al que sacare cortesa de árbol que esté de pie para hazer otros usos, porque irremediablemente se pierden, si no es de aquellos que haian sido cortados con lizencia como se ordena en el párrafo sesto de las adicciones $=$.

14. ${ }^{\circ}$. Por consiguiente, los guardas del Pinal no permitirán y denunciarán a los fragueros que cortasen pino que no han de aprovechar para cumplir las lizencias, pues como se a referido desde luego se han de encaminar a los que están ya echos y sasonados, según dicho párrafo sesto de las acdiciones so pena de pagar el valor de dichos árboles, y además quatro ducados que no permitan se hagan jubrones, tiserones ni tiseras de pinos nuebos sino de las gajadas de los que derribasen para maderas gruesas, pues estas piezas se //266rto pueden sacar de las vigas aserradas en caso de las dichas gajadas de los que derribasen para maderas gru[e]sas, pues estas piezas se pueden sacar 
de las bigas aserradas en caso que las dichas gajadas no den las referidas piezas=.

$15 .^{\circ}$. Que los guardas a prinzipios de noviembre de cada año informen a la Junta del estado actual de los montes o montañas o pinales que están al cuidado de su custodia, espresando en qué paraxes están más adelantados, dónde más despoblados, quáles especies son más raras, nombrándoles por su propio nomvre, y generalmente quántas especies ay, quáles nacen de semilla y quáles de retoño, y los paraxes en que cada especie abunda más, de los incendios que ha [h]avido y en qué partes, y de qué modo juzgan se podrán hacer los replantos con más //266vto adelantamiento, siendo de su obligación el hacer recojer una porción de vaya de los diferentes árboles quando esté sasonada (párrafo dose de las adicciones), cuyos costos se le habonarán del producto de los derechos de los árboles que se cortaren, advirtiéndoseles que por la falta del cumplimiento de este párrafo y demás de esta instrucción se les impone irremediablemente la pena de beinte ducados y pribación de oficio con las demás de la ley, additamento tersero al nuevo plan en cavildo nueve de Febrero de mil setecientos ochenta $y$ ocho=.

16. ${ }^{\circ}$. En los parages que estuvieren vedados o en adelante se vedasen por esta Junta, sea en los Pinales, Montaña o Monte Lentiscal, no permitirán la entrada de ninguna especie de ganado, carbo//267rtoneros ni brederos ni leñadores, etc., denunciado a los contraventores so pena a los dichos guardas de ser responsables a los daños $y$ atrasos que padesieren dichos parajes vedados; $y$ en los no vedados en las partes más pobladas solo se permite la entrada de los leñadores y cerdos arganclados ${ }^{13}$ o glu]iados por pastores, prohiviéndose que estos lleven hachas, machetes, asadones, picos o saias y otro ynstrumento cortante a el Monte, denunciándoles quando se les encuentre según el párrafo quarto del nuevo plan y quince de las adicciones. Y se permite que en la Montaña de Oramas y demás, en los parajes que no estubiesen vedados, se pueda sacar la yerba arrancada, mas no rosada, para precaver el corte de los retoños plantios y árboles nuevos //267vto que nacen de semilla=.

17. ${ }^{\circ}$. Se prohive absolutamente la saca de tierra y estiércol de los dichos tres montes: Pinar, Montaña y Lentiscal, por las escabasiones que se hacen en perjuicio de los árboles nuebos y semillas, y porque se desflora la sustancia del terreno para producir árbol útil en lo sucesivo; y asimismo se prohive por a/h]ora en el Monte Lentiscal la saca de vaga y de maderas y yerva, ni arrancada ni rosada, por estar todo vedado $=$

18..$^{\circ}$ Que los guardas de la Montaña de Oramas o[b]serven el acotamiento espresado en el párrafo quinto del nuevo plan del que se les entregará copia=.

19. ${ }^{\circ}$ Que los guardas hagan las denuncias citando en ellas dos testigos, a o lo menos uno que deponga del conozimiento de la persona //268rto y del delito, y las dichas denuncias las presentarán en derechura a la Junta, como está mandado por auto de la Real Audiencia de veinte de Junio de mil setecientos ochenta y nueve, que está estendido en Junta de treinta de dicho mes y año, pudiendo proceder en los casos que lo esija la naturaleza de la contravención a hacer causas preventibas, remitiéndolas a los corregidores con arreglo a dicho

13 (sic) 
mandato, con aprehensión de los infractores, avisando a la Junta de dicha remisión como está permitido por la real provisión del Real y Supremo Consejo de Castilla, de veinte y dos de marzo de mil setecientos y setenta, a la que está arreglado el párrafo treze del nuevo plan=.

20. ${ }^{\circ}$. Que las lizencias que les presentaren pasado el tiempo que se les señale no les den cumplimiento y las debuelvan al interesado para //268vto que acuda a refrendarla o sacar otra de la Junta de Montes=.

21.. Que immediatamente adviertan incendio por qualesquiera parte que sea en los montes den sin demora alguna parte al señor corregidor y Junta de Montes y a los alcaldes más inmediatos para que acudan y den auxilio de vesinos para apagar el fuego, cuidando de tomar certificación de los fieles de fechos del dia, mes y año en que lo participasen a dichos alcaldes para su descargo con el señor corregidor y junta, so pena en caso de omisión de ser responsables a todos los daños que se causaren en el progreso del incendio por su tardanza en acudir a lo que va prevenido en este párrafo celando rigurosamente que no entren //269rto ganados en los sitios quemados como se manda en la ley citada y estendida en el párrafo terzero de esta ynstruc/c]ión=.

22. ${ }^{\circ}$ Que los guardas del Pinal, obtenido su permiso e intervención, no impidan a los vezinos el sacar de los Pinales todas las sobras y desechos que haian quedado de los cortes, bien sea para la provisión de sus casas o para carboneros o berederos [sic] como los lleven y ejecuten sus obras en la parte que les huviesen señalado fuera de los montes, y denunciarán a los que sin dicha anuencia se entrasen y los tomasen=.

23. ${ }^{\circ}$. Que no permitan la salida de maderas de tea ni leña de sabina ni de ningún género por los puertos de La Aldea y parte de poniente y sud de esta ysla sin espresa lizencia y consentimiento de la Junta, que presisamente havrá de hir espresado en //269vto la dicha lizencia (véase la Junta de diez y siete de enero de noventa y uno=).

24. . Que si en la Montaña por su atraso no tuviesse bresos que puedan dar buen carbón por ser mui nuevos y delgados y tampoco huviese aseviños ni retales o sobras de cortes y troncos secos de que [h]aserlos, harán retirar los carboneros de sus contornos remitiéndolos a el Pinal de Tamadava u otro más sercano que esté vedado para que alli lo hagan con las precauziones y en los términos que va prevenido en el párrafo quarto, para que se puedan proveer los herreros y plateros y demás fraguas.

Vista, se acordó aprobarla, y que se entregue copia de ella a los guardias para su debida instrucción y gobierno.

Se vio un oficio respuesta del director de la Real Sociedad Económica de Amigos del País de esta isla, en que remite a la Junta un plan del modo con que se hace en Castilla y Francia el carbón, con dos representaciones que hizo dicha Sociedad al tribunal de la Real Audiencia. Y en su vista se acordó quedar enterada y que se copie la dicha instrucción y el expediente se ponga original en el legajo de oficios y cartas, y se encarguen por el presente escribano desde el día de hoy dos libros, uno para llevar razón de las denuncias y otro para las de las licencias, los cuales se paguen del dinero que se halla en poder de los guardas. 
Copia de lo que informó la Real Sociedad de Canaria a la Real Audiencia sobre carbón de leña de la Montaña de Doramas en el informe de diez y ocho de junio de mil setecientos ochenta y siete en razón de lo expuesto al tribunal por don Juan Antonio Dominguez //270vto en orden a la conservación de dicha Montaña.

Réstanos solo hablar del carboneo, ramo que a la verdad no es menos perjudicial que necesario. Él ha merecido la atención del Supremo Consejo y la meditación de esta Real Sociedad, que encargada por aquel supremo tribunal (en quien comunicada por su secretario don Pedro Escolano de Arrieta en ocho de agosto de mil setecientos ochenta y cinco de hacer buscar minas de carbón piedra para suplir por el de madera en tanto que se renuevan y mejoran los montes con las providencias que premedita aquel tribunal), ha hecho imprimir carteles y memorias, publicado el premio de cien pesos para el que descubriese mina abundante y practicable, y suministrando las noticias y señas para su busca $y$ descubrimiento; pero solo ha conseguido el desengaño de que no las hay en este pais, porque //271rto todas las muestras que se [h]an presentado con apariencia y semexanza de carbón de piedra han sido piedras sólidas, nada vituminadas ni inflamables. Destituidos ya del auxilio del carbón de piedra para suplir el de madera, no podemos condenar el uso de este en el todo, porque es preciso para las ferrerias, platerias y otras fundiciones; pero hallamos que es indispensable moderar tanto el desorden con que se executa el carbón como el exeso con que se ha hecho general el uso del carvón.

El modo de quemar aqui la leña para hacer este es hacer unas grandes hogueras en que se va aumentando leña hasta que hay muchas brasas y estas se apagan o se sofocan con tierra, cuya operación consume más que triplicada leña de la que se necesita para la cantidad de carbón que resulta; y esto se puede remediar haciendo que se observe el método de hacer carvón //271vto en Castilla que expresa la memoria $n .{ }^{\circ}$ primero o el que prescrive la memoria número segundo presentada a esta Real Sociedad por uno de sus socios de mérito. Establecido el uno de los dos modos de hacer el carbón, resultará que haya menos facilidad de aplicarse a este exercicio, que de pocos años a esta parte se ha hecho casi general en el pago de Valleseco, jurisdición de Teror, y será tamvién menos general el uso del carbón para los hogares de esta ciudad, que podrán alimentar con leña sus fuegos y asi se gastará menos que la que se consume en hacer tanto carbón. Este no se puede prohivir absolutamente como convendría a la conservación de la Montaña, porque tiene usos precisos y no equivale en precio ni calidad el que se puede hazer de pino blanco en el Pinar, aunque es el mejor para las ferrerias. Hoy es pre//272rtociso que se hagan esperimentos a presencia de los tenientes de guardas mayores del método que prescriven las dos memorias que acompañan a este informe, y resultando el ahorro de leña que se indica es de mandar que se hagan número determinado de hornillas o fosas en paraje a propósito y que no le sea licito a ningún hacer carbón en otro lugar ni en otra conformidad, velando y celando los guardas sobre este punto, $y$ aún en caso necesario señalar día en cada semana para hazer el carbón con asistencia de guardia y las más precauciones que parescan convenientes. Sin esto continuará el desorden de las quemas $u$ hogueras, $y$ en tanto que se crien brezos, que es la madera más a propósito y mejor para el carbón, irán 
orillando la montaña los Carboneros y resultarán despoblados que se pretenderán por los Lazarinos o otras. Y como //272vto se ha visto que es pretexto bastante para las datas el que no contienen árboles los terrenos que se piden, se pedirán y se darán, y asi sucesivamente hasta acabar con la Montaña, como han acabado o van acaba[r] con el Lentiscal.

N. ${ }^{\circ}$ 1. $^{\circ}$. Noticia en compendio del método con que se haze el carbón en Castilla es el siguiente. En tiempo de y/n]vierno se va acortando la leña limpiando los troncos de todas las ramas, se va acopiando y juntando en distintos lugares para que se saque, y en llegando el verano se allana un pedazo de terreno de la amplitud que se quiere. Este terreno se escaba de la profundidad de media vara poco más o menos, y en forma redonda; la tierra que se caba se va apartando a la circunferencia. Formado asi la fosa y seca bien la leña, se van poni//273rto endo en el centro de ella los palos más gruesos de forma que resulte de la unión de ellos una choza redonda ancha de habajo y cerrada de arriba, y dejando por abajo y al lado del viento una avertura que ha de servir de comunicación a la voca de la mina que van formando los palos y por donde se le ha de pegar a una porción de rama bien seca que se pone desde el principio en el hueco que forma la choza. Vanse acumulando todos los palos unos sobre otros, de forma que vayan formando un pilón de asúcar o una pirámide obtusa. Después que se ha puesto toda la leña que parezca suficiente, se va vistiendo de alguna rama y ensima se va echando la tierra que está alrededor, y uniéndola de forma que no entre el ayre ni salga el humo, según la ma[g]nitud de la carbonera. Concluido todo, se le da fuego introduciendo //273vto un hacho encendido por la voca de la mina hasta que prenda la leña que se puso en el centro, teniendo cuidado de tapar con tierra por qualquiera parte que salga el humo menos por arriba o por la boca de la mina. De esta forma y lentamente se va penetrando toda la leña, y en viendo que por arriva sale muy poco humo es señal de que está la leña convertida en carbón; entonces se tapa la voca de la mina y respiradero de arriba con tierra y se deja enfriar por el tiempo conducente, según el volumen de la dicha carbonera.

Num. 2. . Memoria sobre el modo de hacer en Francia carbón de leña.

El carbón que ordinariamente se fabrica en Canaria más vien se debe llamar brasa apagada que carbón verdadero, //274rto porque quemándose la leña al ayre libre e impidiéndose esta comunicación después de quemada solo resulta una sustancia ligera, gorosa y fácil de arder, pero que se consume prontamente $y$ se reduze luego a ceniza sin levantar llama ni produzir gran fuego a causa de ser (por decirlo asi) un carbón desustanciado, de manera que para sacar poco carbón es necesario malograr mucha leña. Sería desear que en esta ysla se tuviese cabal noticia del modo de hacer el carbón en Europa, especialmente en Francia, cuia explicación se halla en el célebre Diccionario Encyclopédico tratando de este arte de hacer carbón de leña. Entre otros particulares, se advierte que no son los troncos y maderos gruesos los convenientes para el carbón, porque en estos ya estará casi consumida la parte exterior quando llegue el centro a tostarse a no tomarse antes el trabajo penoso de rajarlo; asi que //274vto se deben preferir para dicho fin los gajos nuevos y leños menudos desde una pulgada a pulgada y media de g[r]ueso y de dos pies y medio a tres pies de largo, teniendo doze experiencia además de que los maderos ya viejos dan un carbón 
muy inferior por defecto de actividad. Tampoco sale bueno el carbón quando está la leña verde o muy húmeda, porque se pierde en él casi una quarta parte; pero la leña seca de qualquier árbol es a propósito, como de roble, castaño, sauce, til, breso, pino, y este carbón de pino es preferible para las fraguas $y$ ferrerias porque suavisa el hierro y no chisporrotea tanto.

Los carboneros eligen para la quema o carbonera un terreno limpio, sólido y llano a modo de era, pero situado en alguna lima para que si lluviere corra [h]azia fuera el agua, el qual //275rto terreno no ha de quedar mui lexos ni tampoco demasiado cerca de parage donde se a de tener la leña cortada, toda por igual, con la mencionada proporción y tamaño y dispuesta en pilar o rimas. Alrededor de esta era, que suele tener quatro o cinco varas de diámetro, no havrá brea, hastillas, maleza ni rama seca por evitar qualquier incendio. En el centro, pues, de la dicha era se clava de firme un palo, mástil o pinpollo que debe tener doze pies de alto, y por abajo el grueso de una pierna. En el contorno del pie de este mástil se han de poner bien arrimadas algunas hastillas y virutas de tea o manojos de ramas secas y que puedan arder fácilmente, y sobre dicho combustible va el carbonero colocando los leños iguales en la siguiente conformidad: una punta del leño contra el suelo y la otra punta //275uto superior contra el mismo mástil, procurando formar alrededor un plan inclinado. Así se van poniendo los leños en torno del mástil, unos arrimados a otros, cuidando de colocar los que fueren más gruesos en el centro hasta que por consiguiente resulta una como peana o basa redonda de cinco a seis pies de diámetro por arriba. Pero es de advertencia que el través de esta primera basa, o peana de leña, se ha de dexar siempre un agugero o conducto por donde pueda tener correspondencia y comunicación el aire exterior de la circunferencia con el centro y la materia combustible del expresado mástil, a cuio fin se pone desde luego tendida en el suelo una solera o palo largo redondo de cinco a seis pulgadas de diámetro que venga desde el pie del mástil [h]azia fuera, alrededor del qual palo se ha de ir armando //276rto la tal peana, de modo que pueda retirarse quando se quiera y quede aquel conducto libre para aplicar por alli a su devido tiempo el fuego necesario.

Hecha ya esta primera vasa, se arma enzima de ella con iguales leños otra segunda; después, enzima de esta otra terzera, y últimamente otra peana quarta, todas las quales van en disminución, coronándose y cubriéndose la superior como un chapitelito de hastillas de tea o rama seca, con lo qual toma la dicha carbonera la figuna de un cono truncado u obelisco de leña.

Concluido este obelisco, pasa el carbonero a ponerle la que llaman camisa, y para ello empieza a cuvrir las rendijas exteriores de los leños, primero con algunas yervas si las huviere a mano, y luego con una capa de tierra o también del cisco y ceniza de la misma car//276vtobonera si ya se ha hecho en ella algün carbón. Esta operación se executa tomando con la parte hueca de una pala la tierra o el cisco echándola por igual sobre el tal obelisco o pira de leña y uniéndola y apretándola luego muy bien con la parte plana de la misma pala, de manera que quede toda la pira forrada de una costra de tres a quatro pulgadas de espesor, excepto solamente el extremo de la parte superior, que se dexará algo descuvierta, para que el fuego se encamine con más facilidad al exe de la pira, que es el mástil. 
Cubierta esta del modo insignuado se abrirá el prevenido agugero o conducto de la primera basa, sacando el palo con que se habia formado, se llenará de rama bien sea o de rafitas de tierra, y se le pegará fuego, el qual asi que //277rto empieza a arder da lugar a que se establezca una corriente o correspondencia de ayre desde la parte exterior de la primera peana de leña hasta su centro, con lo que se va encendiendo el mástil a lo largo, y por consiguiente se va comunicando y propagando el fuego por toda la pira.

Entretanto, se verá salir por la abertura de su punta o parte superior un humo blanquecino y espeso, y luego que el carbonero hiziere juicio por la disminución de la cantidad de este humo de que el mástil ya está quemado, subirá por una escalerilla de mano (en lo que no corre ningún peligro), y echando por la referida avertura superior como un par de cestas de carbón para fomentar el incendio la volverá a tapar; y lo mismo hará con el conducto de la basa inferior, todo a fin de que no entre ningún ayre, ya bien que siempre será indispensable //277vto que el carbonero esté atento a aumentar la acción del fuego abriendo o cer[r]ando algunos agugeros de trecho en trecho de la pira con el cabo de la pala que clavará en la costra de tierra por la parte que viere que no se habate con igualdad, pues solo quando esta se va aplastando uniformemente es quando se hecha de ver que el fuego está bien destribuido.

En el horno o pira regular de carbón se mantiene ardiendo tres o quatro dias. Al dia segundo por la noche, toda la camisa de tierra se pone roja y como una ascua; entonces es necesario volver a cubrir la pira con nueva tierra o cisco, apretándola o puliéndola con la pala para cerrar todas sus grietas. Y luego que el fuego se huviere apagado del todo, abatiéndose con igualdad la gira//278rto se procurará descubrir un poco el carbón a fin de que no tarde en enfriarse. Para esto un homvre con una especie de rastrillo de yerro va apartando alguna porción de la camisa de tierra, pero no toda por el peligro de que la demasiada comunicasión del ayre no vuelva a encender el carbón; y para evitarlo con más seguridad, otro homvre volverá al mismo tiempo a echar con la pala sobre la pira la tierra ya apartada u otra más fresca.

Finalmente, quando pareciere que está ya bien frío todo el carbón, se abrirá la pira por un lado para verificarlo, y si lo está en efecto se sacará y transportará como y a donde se quiere.

Se acordó se copie en esta Junta el modelo y forma con que ha dispuesto esta Junta se entiendan de hoy en adelante las licencias, el cual es el siguiente:

Dase Lizencia por esta Junta de Montes (a N.) vecino del lugar de ... para que con asistencia de qualesquiera de los señores guardas mayores o menores pueda sacar en el espazio de treinta dias de la Montaña de Oramas (o Pinal o Monte Lentiscal) tal porción de madera (y se nombrará la que fuere; si fuere leña, se dirá que seca) en parage abierto y no vedado, absteniéndose de catar los pinos y cortar la madera en las orillas ni en donde huviese despoblados de árboles, sino en donde se advirtiese más espesura con orden y método, salpicando el corte de árboles, dejando [h]orca y pendón en el que no fuere necesario cortar por el pie por no nesecitarlo el grueso y alto de la pieza que se huviese de sacar, haviendo de ser obligación del guarda a quien se presentase esta lizencia 
tomar razón a su espalda o a continuación del dia. mes y año que se le presentare del en que se verificó dicho corte y del número de árboles que se huviesen cortado para llenar la lizencia, cobrando por cada uno de los gruesos quatro reales vellón corrientes y dos por cada mediano para coste de los replantos, sin cuio ex[h]ivo no se permitirá sacar la dicha madera cortada del dicho monte; los quales cobrará el guarda a quien se comete esta lizencia y los entregará ala Junta con esta y demás cada tres meses, so pena de responsavilidad, y no podrá llevar por el corte de esta lizencia más derecho, dietas y salarios que ocho reales vellón corrientes ( $y$ si fuere para aperos y no más que para tres árboles avajo, quatro reales vellón) y denunciará y procederá contra los fragueros que después de señalado el corte se ecsediesen en él y mudasen de puesto. Dada en Canaria en tal día, mes y año.

Se vio un memorial de D. Pedro Cabrera, vecino de Telde, para sacar del Monte Lentiscal dos portezuelas de dos lagares de acebuche, que podrá llevar cada una cinco cuartas de largo, de ancho dos y una tercia de grueso. Se acordó que de los árboles secos que hay en el Monte de acebuche se corte uno con anuencia del guarda, quien cuidará que lo saquen trozado sobre bestias, pagando el valor del árbol como se previene en el Plan de Monte.

Otro memorial de D. Andrés Cabrera, vecino de esta ciudad, pidiendo licencia para sacar del Pinar diez tosas, diez vigas, treinta jubrones para la composición de su casa. Se concede la licencia.

Se vio un oficio de la Real Sociedad Económica de Amigos del País en el que habla de los decretos de la Real Audiencia sobre el acotamiento de algunos sitios en el Pinar para semilleros y replantos proporcionados a las jurisdicciones confinantes, tal y como había pedido dicha Sociedad, añadiendo:

Y por lo que mira a la otra providencia del mismo superior tribunal sobre los intolerables excesos que se cometen en la Montaña de Doramas con motivo de la fábrica de carbón, acordó igualmente se pasen a vuestras señorías copias de lo que la Sociedad informó en el asunto a la Real Audiencia en diez y ocho de junio y tres de octuvre de mil setecientos ochenta y siete y de las memorias sobre el método de hacer el carbón tanto en Castilla como en Francia, con los diseños de las carboneras que para mejor inteligencia las acompañaban. Añadiendo ahora que a la Junta acaso opinare que se pueda permitir la fábrica de algún carbón de la leña de la Montaña, desearía la Sociedad no son mui grandes fundamentos que semejantes quemas solo se executasen a distancia de todo arbolado, $y$ aún fuera de sus linderos $y$ orillas $y$ con la qualidad de que para ello no se pudiesen emplear sino los desperdicios de los cortes y retales inútiles, prohiviéndose toda tala de la madera viva. Nuestro Señor guarde a vuestras señorias muchos años. Ciudad real de Las Palmas, veinte y ocho de febrero de mil setecientos noventa y un año. Don Josef de Viera y Clavijo, director. Señores de la Junta de Montes de la ysla de Gran Canaria.

Acordóse en vista del oficio que antezede se espidan cartas a nomvre de esta Junta por el presente escribano a la maior vrevedad, so pena de responsavilidad a los tres guardas y sobreguarda de la Montaña de Oramas y al de los Pinales para que desde luego y sin pérdida de tiempo señalen dos sitios en cada uno de dichos montes fuera de las orillas de lo interior, a bastante distancia de aquellas, en donde quemen los carboneros el carbón de retales o de vrezo y 
asebiño, so pena que de consentir lo contrario se procederá contra dichos guardas con el maior rigor y denunciarán a los contraventores y sitarán para un día determinado, lo más vreve que sea posible, a todos los que se exercitan en este tráfico para que se presenten a la Junta, y esta les instruirá del modo de hacer el carbón con aprovechamiento y sin el doloroso desperdicio por el modo con que lo están fraguando.

Se vio la respuesta dada por el guarda D. Gregorio Ponce Díaz de que no puede atender a cumplir con su encargo de guarda de la Montaña de Doramas de que está posesionado por medio del sobreguarda Francisco Tomás a quien se le había encargado lo citase para comparecer a esta Junta. Se acordó que se le escriba para que comparezca y se presente ante esta Junta, y en caso de no poder cumplir con su encargo renuncie formalmente en esta Junta.

Entró Fernando de Quintana, receptor de la Real Audiencia, con un pedimento y decreto de ese tribunal, en el cual mandan que la Junta de la Real Sociedad Económica de Amigos del País y la de Montes informen sobre la petición presentada ante ese tribunal el 5 de marzo de 1791 por D. Roque de Torres, vecino de esta ciudad, en la cual señala que, habiendo ocurrido a la Junta de Montes en 3 de septiembre del año pasado para obtener licencia para cortar una poca de madera para la fábrica de su casa y la carena de dos barcos que tiene en el tráfico de la costa de pesquería, se le concedió la licencia; y remitida al guarda para su corte se verificó este, cuya madera subsiste aún en el Pinar, pero con motivo de haberla detenido el alcalde de La Aldea por suponer es para llevarla al puerto de Santa Cruz, en fuerza de la orden de esta superioridad, tiene el perjuicio de tener parada la fábrica de su casa y la carena de los barcos; por lo que tiene pronto, luego que llegue la madera a esta rivera, ponerla de manifiesto para que se verifique lo que dice, y solicita providencia para que el alcalde no impida el embarque

Y se acuerda se llame a junta para el lunes, catorce del corriente, para dar respuesta.

\section{6}

\section{1/Marzo/14. Canaria.}

Junta con asistencia de D. Manuel del Río y D. Isidoro Romero, regidores perpetuos, D. Ignacio Díaz y D. Andrés Barreto, diputados.

Habiéndose tratado sobre el informe pedido por la Real Audiencia en auto de 5 de marzo, que está en la Junta que antecede, sobre la licencia solicitada por D. Roque de Torres para sacar madera por el puerto de la Aldea, madera que tiene cortada, se acordó se informe al tribunal ser cierto habérsele concedido dicha licencia antes que se cerrase dicho puerto. Y por esta razón no se le ofrece reparo que se le permita sacarla con tal que la traiga a esta capital y a su llegada manifieste razón de la que sacare por dicho puerto, visada y firmada de aquel alcalde, que deberá presentar en esta Junta. Y como se ha entendido que por aquella parte hay otros puertos y por la del sur, por donde se están sacando madera, que no están cerrados, le parece a la Junta conveniente que se señalen dos puertos por la parte del sur y se cerrase el resto para que los vecinos de La Aldea que necesiten traer a esta ciudad madera lo 
hagan con los mismos requisitos que la de Torres, teniendo licencia de la Junta.

Memorial del escribano menor D. Francisco Martínez de Escobar pidiendo licencia para sacar del Pinar dieciséis jubrones, veinticuatro tijerones, once tosas y dos vigas para la fábrica de su casa. Se acordó conceder la licencia.

Memorial presentado por D. Andrés Barreto para que se le conceda licencia, renovando otra que tiene pedida el año pasado de 1790, para sacar del Pinar doce vigas de siete varas, veintiocho tosas, setenta y cinco jubrones, cinco vigas de diez y once varas y cincuenta tijerones. Se acordó conceder dicha licencia.

\section{7}

\section{1/Marzo/18. Canaria.}

Junta con asistencia de D. Manuel del Río y D. Isidoro Romero, regidores perpetuos, D. Ignacio Díaz y D. Andrés Barreto, diputados, y D. Sebastián de Quintana, sindico personero.

Entró el receptor Fernando de Quintana con auto de la Real Audiencia, con fecha de 14 de marzo de 1791, por el cual, habiendo visto el acuerdo de la Junta de Montes de 8 de febrero, que incluye copia de las cuentas dadas por los guardas del desbroce hecho en el Monte Lentiscal y la solicitud de que se contribuya a su importe el premio de su trabajo a las personas que refiere y lo expuesto por la Real Sociedad Económica de Amigos del País en 28 del mismo mes, mandaron que Agustín Velázquez exhiba la cantidad de que se hace cuenta, a excepción de los 10 pesos dados a Nicolás del Castillo, que se le abonan y conceden sin emplear el real dado al alguacil de orden de D. Isidoro Romero y los 3 de la llevada de las vagas, correspondiendo las demás partidas a la porción que se vendió al convento de religiosas de San Bernardo y Salvador de Quintana, de cuya cantidad y de la que existe en poder de Antonio Rodríguez se pague a este los salarios devengados del tiempo que ha sido guarda de la ciudad en atención a que por la Audiencia no tenía sueldo asignado y por esta consideración se le libró una gratificación en penas de cámara; y que por ahora, y mientras el cuerpo de la Real Sociedad Económica de Amigos del País se dedique al cuidado y aumento del Monte Lentiscal, se le encarga el desbroce y limpia anual de él, y de lo que produzca dé razón cada año a la Real Audiencia abonando solamente cada año al portero de la ciudad los 5 pesos que le señaló la Junta por el trabajo de citar a sus individuos.

Habiéndose tratado lo que contiene dicho auto, sobre todo lo de que la Real Sociedad Económica de Amigos del País entre exclusivamente en los replantos y desbroces del Monte sin intervenir en ello ningún diputado de la Junta que le represente, ya que en ella reside el gobierno económico y gubernativo de los montes por representar a la ciudad, según lo dispuesto por dicho tribunal por auto de 7 de diciembre de 1787, queda la Junta desairada y con una sombra y sospecha, como que necesitan de una mano que los dirija, cuando parece que a dicho real cuerpo solo le incumbe pedir lo que le parezca conveniente según sus luces para el adelantamiento de los montes o en la superioridad o en la Junta. Por lo que se acordó representar al tribunal se digne mandar 
intervenga en los dichos desbroces un individuo de esta Junta que la represente para que, si no se hacen según reglas de la Junta, lo impida y sostenga la autoridad de la misma; que conozca esta del destino y producto de la leña y de sus cuentas pagando a la Real Sociedad de su líquido; que se señale anualmente 10 pesos de dichos fondos al amanuense que nombrase la Junta para que extienda las actas, saque testimonio, copie oficios y 2 pesos para papel y el valor de dos libros que mandó dicho tribunal se hiciesen, uno para las denuncias y otro para las licencias.

Memorial de Antonio Alvarado, vecino de esta ciudad, para sacar de la Montaña de Doramas ochenta palos de ligazón, codaste, yugo, veinte palos de latas, seis palos de cintas, sobrequilla, pala de tajamar, quilla, roda, timón, costones, ligazón para una lancha, cuatro picaderos y veinte docenas de tablas para fabricar un barco de la costa de cincuenta palmos de quilla con la lista jurada del oficial Miguel Farías. Se acordó se entienda la licencia para el Pinar, a excepción de la quilla y madera de la lancha.

Memorial de D. Domingo Galdós pidiendo licencia para sacar del Pinar y de la Montaña de Doramas cincuenta piezas de ligazón dobles, siete manos dobles de cintas, roda y codaste, yugo y aletas, palo de tajamar, sobrequilla, tres timones, cuatro palos de arbolar, trancaniles, durmientes, tablado veinte docenas, palos de bomba, curvas, treinta piezas de aposturas dobles y de la Montaña catorce parales, una quilla de barco de descarga y de otra lancha y la madera de dicha lancha, dos palos de cuatro varas de largo para cuadernales para la fábrica de un barco que está en la lista del oficial Blas de Miranda. Se acordó concederla.

\section{8}

\section{1/Marzo/30. Canaria.}

Junta con asistencia de D. Manuel del Río y D. Isidoro Romero, regidores perpetuos, D. Ignacio Díaz y D. Andrés Barreto, diputados, y D. Sebastián de Quintana, sindico personero.

Reconoziendo esta Junta que por ser los Pinales tan extensivos de terrenos no pueden ser guardadas por un tan solo guarda, siguiéndose por esto muchos perjuizios en los diversos cortes y talas que se hazen por las partes muy remotas sin lizencia de la Junta y de los guardas que residen en Tejeda, que solo puede cuidar de la mitad de ellos por la parte que corresponde al norte, conceptúan por mui preziso el que se ponga otro en el lugar de Tiraxana que cuide de la otra mitad de la parte del sud. En esta atención acordó nomvrar por guarda deste trozo de pinal para que, en calidad de segundo zelador, cele y vijile su conservación, a el capitán don Josef Navarro; y para tener la competente aprovación se saque testimonio deste acuerdo y se pase al Real Acuerdo por el señor don Ygnacio Diaz.

Memorial de D. José Hernández, vecino de Tejeda, para sacar del Pinar doscientos jubrones, doce vigas, seis cumbreras, doscientas doce tijeras y ocho palos que consta en la lista del carpintero para la fábrica de dos casas y sus cocinas. Se acordó conceder la licencia. 
Memorial de D. Domingo Henríquez, vecino de Teror, para sacar de la Montaña de Doramas ramazón y otros desechos inútiles para quemar un horno de cal por la parte de Teror. Se concede la licencia, interveniendo en ello el guarda de la parte de Teror, y con tal de que la leña a de ser de zarza, retales, altabacas y de ramazón del aya cortada, y de ninguna manera de árbol alguno de pie ni nuevo ni viejo.

Se vieron dos cartas, una del guarda de Teror y otra del sobreguarda puesto por la Real Audiencia.

Muy venerado señor, de mi primera atención mediante a lo últimamente resuelto por los //290vto señores de la Junta acerca de que hagan carbón en la Montaña Doramas en los paraxes que no perjudiquen que son reducidos a pagos de la Agua del Laurel y en Montaña Alta de Guía y el número de los carboneros asienden a diez y seis, pertenecientes a la jurisdic/c]ión de Arucas y Moya, a quienes tengo prevenido concurran a presentarse ante el escribano de Ayuntamiento para que se les haga saber ocurran a dichos parajes a hazer dicho carbón. Es quanto se ofrece decir a vuestra merced, cuia vida guarde Dios muchos años. Costa de La Yraga, a veinte y cinco de marzo de mil setecientos noventa y un años. Beso las manos de vuestra merced, su verdadero servidor. Francisco Thomás Hernández.

Muy señor mío, reziví la de vuestra merced a la fecha del día catorze del corriente mes de marzo, y haviendo visto lo que en ella me comunica por acuerdo de la Junta y de mando de los señores de Cavildo aserca de montes y montañas de partiziparle a vuestra merced //291rto cómo [h]e concurrido con los demás compañeros, que lo fueron don Francisco Thomás Hernández y Juan Martín, en el paraje señalado y que se destinó, que lo fue en el barranco del Agua de Laurel; y hallándonos los tres juntos, comunicamos sobre lo mandado por dichos señores de Cavildo y señalamos por lo que hase a los oficiales de carbón el plan del barranco para sitios, para que de alli a una mano y a otra hagan su leña, $y$ el número de oficiales de carbón que [h]ay en este lugar de Teror son los siguientes: Domingo Vayón= Matías Bayón= Josef Baión= Bartholomé Baión= Juan Dominguez $=$ Salvador González $=$ Eusebio González $=$ Josef de Quintana $=$ Josef Cobella $=$ Lorenzo Garsia $=$ Christóbal Herrera $=$ Vizente del Rosario $=$ Lorenzo Suárez $=$ Juan Ramón $=$ Josef de Cárdenes $=$ Vizente Cárdenes= Bartholomé Moreno= Juan Antonio = Juan Gregorio $=$ Gregorio de Quintana= Blas Pérez $=$ Josef de Herrera= Antonio Suárez $=$ Salbador Yanes $=$ Josef Ygnacio de Quintana= Vizente Herrera= Christóbal Hernández $=$ Sebastián Guerra $=$ Salvador Dominguez $=$ Blas Suáres $=$ Juan Pulido $=$ Francisco $/ / 291$ to de Ortega $=$. Y paresiéndome ser muy crezido el número de los que se ocupan en haser carbón en este lugar, me paresía según mi dictamen y el de los compañeros por lo que respecta a este lugar se nombraran ocho, pues hay bastante número para la herreria deste pueblo, y son los siguientes:= Domingo Baión= Matias Baión= Josef Bayón= Bartholomé Bayón= Salvador González= Eusebio González= Josef Herrera= Gregorio de Quintana. Todo lo que pongo en la noticia de la Junta para que determinen como superiores por no hallarse leña y la que hay estar muy retirada, quedando rogando a Dios Nuestro Señor guarde su vida muchos años. Teror y marso, veinte, de mil setecientos noventa y un años. Beso las manos de 
vuestra merced su mayor servidor. Francisco Dominguez Falcón. Señor don Francisco Martinez de Escobar.

Se acordó se llame a Junta de Monte para el lunes 4 de abril.

\section{9}

\section{1/Abril/6. Canaria.}

Junta con asistencia de D. Manuel del Río y D. Isidoro Romero, regidores perpetuos, D. Ignacio Díaz, diputado, y D. Sebastián de Quintana, síndico personero.

Fernando de Quintana, receptor de la Real Audiencia, hizo saber un auto de ese tribunal con fecha en Canaria a 6 de abril de 1791 por el cual, habiendo visto el expediente promovido por D. Roque de Torres, vecino de esta ciudad, agraviándose del impedimento puesto por el alcalde de La Aldea de San Nicolás para que no extraiga de él a esta ciudad madera para la fábrica de su casa y la carena de dos barcos que trae al tráfico de la costa de pesquería y para lo cual le fue concedida licencia por la Junta de Montes con lo informado por esta y la Real Sociedad Económica de Amigos del País, mandaron que se permite al susodicho que pueda embarcar por el puerto de La Aldea la partida de madera que tiene cortada con las condiciones que dice la Real Sociedad Económica de Amigos del País, trayendo la correspondiente guía del alcalde de aquella jurisdicción, como está mandado. Y la Junta en las licencias que en lo sucesivo hubiere de dar para el corte de madera, tanto para la fábrica de edificios como para la construcción de barcos, exprese el paraje en que se haya de hacer el corte de piezas y el puerto por donde se haya de sacar con asistencia del guarda y guía del alcalde para la correspondiente guía, según está determinado. Y en cuanto al inmoderado corte de la leña de sabina, la Junta dé las correspondientes providencias que lo impidan.

Se acordó obedecer y se guarde, y que los escribanos que despachasen las licencias para corte de madera que diese la Junta mencionen en ella precisamente el paraje donde se haya de cortar y señalarán el puerto que corresponda, según el trozo donde se corte por donde se haya de sacar, según lo acordado por la Junta; y prevendrán también la obligación en que queda de perder la madera de no solicitar guía antes de embarcarlo por alguno de aquellos puertos del alcalde más inmediato y de presentarla a esta Junta en treinta dias luego que aporten a esta capital.

Haviéndose tratado y conferido sobre las cartas de los guardas de la Montaña Doramas, don Francisco Dominguez y el sobreguarda don Francisco Thomás, estendidas en la Junta antesedente en asunto para hacer el carbón en la dicha Montaña según se les havía prevenido por la Junta. Se acordó se aprueban los sitios señalados para los carboneros de Teror, Moya y Arucas en el varranco del Agua de Laurel hazia donde están los cepones de barbusano y Montaña Alta de Guía, y en su consequencia se prohive desde el dia de [h]oy en adelante el que los dichos carboneros, inclusos tamvién los de la parte de Guía y Gáldar, no puedan hacer el dicho carbón sino en los sitios referidos so pena de pribación de este oficio y que quince dias de cársel y se reduzen en veinte $y$ uno respecto a ser el número tan crezido el de la parte de Teror, el qual asiende a treinta $y$ seis que bastan para [d]estruir toda la montaña. Y estos sean los 
siguientes por la parte de Teror los que han parecido entre ellos que mejor observarán lo dispuesto por la Junta en esta materia:
1. Eusevio González
2. Salbador González
3. Bartholome Baión
4. Gregorio Quintana
5. Christobal Herrera
6. Juan Falcón
7. Vizente del Rosario
8. Bartholomé Moreno
9. Juan Gregorio
10. Josef Herrera
11. Salbador Yanes
12. Vizente Herrera
13. Domingo Baión
14. Christóbal Hernández
15. Blas Suárez
16. Matias Vayón
17. Josef Vayón
18. Juan Dominguez
19. Juan Ramón
20. Antonio Suárez
21. Salvador Dominguez

Sáquese testimono deste acuerdo y de la lista de los nominados y se pase a los tres guardas de la dicha montaña por medio de los señores guardas maiores; y se escriba al sobreguarda don Francisco Thomás y al guarda Juan Martín Custodio remitan las listas del número y expresión de nombres de los carboneros de la parte de Moya, Arucas, Guía y Gáldar para reduzirlos al número, como se [h] [h]echo con los de la parte de dicho Teror, informando quáles de ellos serán mejores para el desempeño de su oficio.

Se vio un oficio del director de la Real Sociedad Económica de Amigos del País en que incluye un plan de la división de los Pinares que conviene hacerse para el acotamiento de ellos, y estando conforme a los informes e intención de esta Junta, se acordó se copie en esta acta.

$Y$ que se haga dicha triple división por el guarda del Pinal por los linderos espresados en dicho plan, de que se le remitirá copia. Y se declara por acotado $y$ vedado en el trozo primero a la parte derecha que devide el varranco de Chamarrican subiendo por él a salir a las Gelechas //295vto y Cruz Grande de Tirajana desde el mar; en el segundo se veda la mitad ysquierda, cuia división se prinzipia desde el barranco de Veneguera a entrar por medio del Galgal del Mulato derechamente hasta asomar a la Cuesta de la Viuda, barranquillo arriba del Juncal hasta el filo de la cumvre; y en el terzero trozo, que incluie el Pinal de 
Tamadava, se veda la parte derecha subiendo a Artenara por medio del barranquillo del Risco. Y la dicha veda se entienda por veinte años, con arreglo a las reales órdenes, y que en ellos no se deje entrar género alguno de ganados, carboneros ni fragueros ni brederos bajo la pena, que serán castigados con el maior rigor de derecho. Y se saque testimonio deste acuerdo y plan y se pase //296rto a los alcaldes, diputados y personeros de las poblaciones inmediatas a dichos Pinares para que informen sobre esta dibisión lo que se les ofrezca y se conteste a la Real Sosiedad por medio del señor don Andrés Barreto con testimonio deste acuerdo. Y se señala para sacar las maderas cortadas en el primero trozo que está entre el barranco de Tirajana y del Ganiguin, el puerto de Maspaloma[s] y el de Mogán; para las del segundo trozo contiguo al primero, que se llama el Pinal de la Ynagua, que está entre el varranco del Ganiguin y el de la Aldea el puerto del Ganiguin y Veneguera; y para el terzero, que está entre el barranco de la Aldea y el Agaete, que comprehende el Pinar de Tamadava a el puerto de Mogán y del de Agaete. Y an de traer tornaguía los que cortan en el primero trozo del alcal[de] //296vto de Tirajana, los que cortaren en el segundo del de Texeda y los que en el terzero de de Lagaete, so pena de perder las maderas y de incurrir en las demás penas que haia lugar. Y para que cada uno de los tres dichos trozos esté bien custodiado y se observe lo dispuesto por el superior tribunal de la Real Audiencia y acuerdo de esta Junta en punto a su conservación y adelantamiento, se acordó para que haia en cada uno un guarda respecto tenerse para el primero trozo consultado un vezino de Tirajana, y el segundo tendrá otro en exercicio que reside en Texeda. Se solizite permiso del dicho tribunal para poner otro en Artenara que cuide del terzero trozo con el correspondiente oficio que se pasará al Real Acuerdo por medio del señor don Andrés Barreto //297rto; y a los alcaldes de Tirajana, Tejeda y Agaete se les escriba a nomvre desta Junta que no permitan sacar madera aunque haian obtenido lizencia para su corte por dichos puertos sin la guia correspondiente despachada por ellos, según lo mandado el superior tribunal de la Real Audiencia.

$\backslash$ Plan de Linderos del Pinar que mandó la Sociedad a esta Junta para que hiciese el acotamiento/

Muy ylustres señores. El sustituto de censor, en cumplimiento del encargo que vuestra señoria fue servido hacerle en Junta de veinte y uno del pasado para que solicitase notizia de los acotamientos que convendrá hacer en el Pinar a fin de que libertándolo en quarteles del continuo hollar y morder de los ganados pueda restablezerse reproduziéndose de sus propias semillas, ha procurado informarse de personas prácticas y de conozimiento los Pinares. Y puede manifestar a vuestra señoría que tiene por racional //297vto y verídica la razón siguiente:

El Pinar se divide en tres partes según su propia situación: La una mira acial sur y tiene por linderos barranco de Tiraxana a salir a la cumvre, cumvre adelante a la Goleta, barranco del Ganiguín hasta el Mar; la otra está a poniente y se llama el pinar de Laynagua, que linda desde el barranco del Ganiguin hasta el barranco de la Aldea siguiendo uno y otro barranco hasta la cymbre; y la terzera corre desde el barranco referido de la Aldea de San Nicolás hasta el de la Agaete, ciguiendo hasta la cumvre entre uno y otro barranco. 
En cada una de estas partes del Pinar se debe acotar y vedar a las hachas y ganados cierta parte, como la mitad de cada una, y podrá ser en esta //298rto forma:

En el pinar primero, deslindado por el barranco que dizen de Chamorican arriba a salir a las Gelechas partiendo a dar a la Cruz Grande que está debaxo de la cumvre.

En el segundo saliendo por el barranco de Veneguera a partir el Galgal del Mulato hasta asomar a vista de la cuesta de la Ruda, barranquillo arriba del Juncal a la cumvre.

Y el terzero barranquillo arriba del risco, partiendo el Pinar de Tamadaba a salir a Artenara. En esta conformidad quedan divididos los tres Pinares o las tres de que se compone nuestro Pinar en dos mitades cada una, y así se podrá acotar una mitad de cada una de dichas tres partes, bien sea la mitad de arriba o bien la mitad aciabajo, según a cada vesindario respectivo acomode mejor para este //298vto primer acotamiento, pues para el fin de conseguir el restablezimiento de lo que se acotare lo mismo vale la una mitad que la otra en cada una de las tres partes de dicho Pinar sin que sea preciso el beneficio de siemvras ni replantos, según lo que se produce por la nacencia de sus mismas semillas y raizes en cada año. Pero es indispensable la separación de los ganados y la prohivisión de los fuegos, que causan tan repetidos incendios con gravísimo daño de aquel monte tan útil y necesario, y que se siga constantemente la custodia y veda por los veinte años que dispone la última real orden sobre replantos de montes.

Si vuestra señoría tubiere estas noticias por de algún mérito o aprecio //299rto, podrá servirse de comunicarlas a la Junta de Montes a fin de que si lo tuviese por conveniente las partizipe a las justicias, diputados y personero de los pueblos circunvezinos al Pinar para que informen, enterándoles de que el acotamiento está resuelto y se executará para evitar con esta prevención el que intenten con escusas y supuestos inconvenientes tratar de impracticable la veda y guarda de los quarteles que se acotaron, con las miras de que los ganados continúen en la misma desordenada libertad que hasta ora, quando por el contrario deberán ser ellos mismos los guardas y celadores de lo que se acotase $y$ los responsables a las contravenciones voluntarias que puedan resultar de su omisión o condecendencia. Vuestra señoría, con su profunda //299vto meditación conocerá lo más útil, que es lo que desea el vicecensor. Josef de la Rocha. Visto en Junta de 28 de Marzo de mil setecientos noventa y un años. Rusell.

Se vieron cuatro memoriales pidiendo licencias para madera:

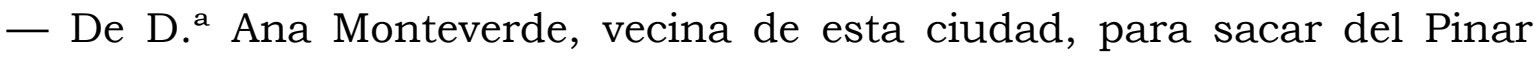
treinta jubrones, treinta tijeras y veinticinco piezas cuadradas entre tosas y vigas, que consta en la lista jurada del oficial para la fábrica de una casa.

- De D. Juan Rodríguez, vecino de Gáldar, para sacar del Pinar inmediato a Agaete, según lista del oficial, cien jubrones, cien vigas, doscientas tijeras, veinticinco tosas y veinticinco umbrales para la fábrica de una casa de alto y bajo en Gáldar.

- De José de Cárdenes, vecino de esta ciudad en el pago de Tafira, para sacar del Pinar de Tejeda ocho cargas de tijeras, dos cumbreras, dos pies, 
tres o cuatro palos de tosas y cuatro cargas de jubrones, según la lista jurada para la fábrica de una casa.

- De D. Valentín Vázquez Naranjo, para sacar del Pinar treinta jubrones, doce tosas y docena y media de tijeras para la fábrica de una casa en esta ciudad.

Se acordó conceder las licencias para sacar la madera del Pinar con arreglo al nuevo plan y acotamiento.

Se acordó que en adelante no se admita memorial donde se solicite licencia para corte de madera en el Pinar sin que venga expresado el paraje y sitio donde se ha de cortar y puerto por donde se ha de embarcar.

Memorial de D. Gregorio Ponce Díaz, subteniente de milicias provinciales y alcalde real de Arucas, en el que renuncia a su nombramiento de teniente de guarda mayor de la Montaña de Doramas que se le hizo el año antecedente por estar ocupando el de alcalde real y los negocios de su casa. Se acordó admitir la renuncia, y en su lugar se nombra a D. Diego de Medina, vecino de Arucas, y se comunique a la Real Audiencia para obtener la competente aprobación.

Se acuerda que Agustín Velázquez, guarda que fue del Monte Lentiscal, entregará 18 [reales] de plata a la primera Junta que haya para comprar una resma de papel para el gasto de testimonios, oficios y cartas que se están sacando.

\section{0}

\section{1/Abril/14. Canaria.}

Junta con asistencia de D. Manuel del Río, regidor perpetuo, D. Ignacio Díaz y D. Andrés Barreto, diputados, y D. Sebastián de Quintana, síndico personero.

El señor sindico personero dijo que, en atención a haber sido preciso darse cuenta en este dia de lo extendido en la Junta de 11 de marzo en la que se halló presente, y aunque en ella oyó el tenor de la fórmula de dar licencia de madera gravando a los pretendientes con las cuotas que alli se citan para replantos, lo cual no se contradijo entonces creyendo fuese con arreglo a reales instrucciones; pero que reflexionando ahora lo perjudicial que es al público tal gravamen, pide se llame a Junta convocando a todos los señores que la componen para conferenciar sobre este punto, teniendo presente las actas posteriores, la real orden de 48 y lo demás concerniente al asunto, suspendiéndose entre tanto lo acordado. Se acordó se haga como lo propone el señor síndico, adelantando tener descargada su conciencia porque este mismo día se podía resolver el asunto mediante a haber citado al señor D. Isidoro Romero y estar este en la calle no habiendo comparecido, sin embargo de habérsele vuelto a citar; y que en el interin se escriba carta a los guardas para que se suspenda los efectos de dicha Junta.

Memorial de Salvador Navarro, vecino de Tejeda, para sacar del Pinar cinco cumbreras, setenta jubrones, diez vigas, diez tosas, trescientas tijeras y seis tirantes para la fábrica de dos casas, cocinas y demás accesorios. Se concede la licencia. 


\section{1}

\section{1/Abril/16. Canaria.}

Junta con asistencia de D. Manuel del Río y D. Isidoro Romero, regidores perpetuos, D. Ignacio Díaz y D. Andrés Barreto, diputados.

Se vio un decreto de la Real Audiencia por el que se confirma el nombramiento de guarda de la Montaña hecho en D. Diego de Medina para Arucas; se acordó se obedece y se le dé el título por el señor corregidor.

El señor don Ysidoro Romero dixo que, siendo assí que está mandado por uno de los puntos fundamentales de esta Junta que se dignó aprobar el tribunal superior de la Real Audiencia y por la real zédula del año de quarenta y ocho el que se cobren los derechos asignados por cada pie de árbol, y respecto a que la Junta ha suspendido los efectos sin consul//304rtotarse antes con el tribunal superior, protesta de nulidad el dicho acuerdo; y que entre tanto no se consulte no sean de su cuenta y cargo los maravedies que se dejen de cobrar, reservando el dar las razones que le asisten para fundar esta protesta y su voto en la materia quando con citación del señor personero se convoque a Junta y se trate como corresponde.

$Y$ en su vista el señor don Manuel del Río dijo que, aunque es cierto que por la instrucción que se formó para esta Junta de Montes y se mandó guardar por el tribunal superior de la Real Audiencia estaban sujetos los que cortavan madera a pagar por cada árbol la quota señalada, aunque en la real orden del año de quarenta y ocho solo manda Su Magestad que se repongan tres árboles en el lugar de uno y que por su efecto se pague, haviéndose inspecionado con bastante madurés en la Junta selebrada en catorze de este sobre la //304vto quota impuesta, para lo qual fue llamada; y no pudiéndose evacuar a causa de la no asistencia del señor don Ysidoro, y considerar no poderse poner en práctica dicha instrucción sin nuevo mandato de la Real Audiencia, lo que ya podia haverse hecho en dicha Junta, y consultádose con el superior tribunal le parese al señor exponente no hay motibos para que se le proteste a esta Junta, porque haviéndose evacuado en dicho dia podia haver quedado en los términos que el tribunal tubiese a bien.

$Y$ los señores don Ignacio Diaz y don Andrés Barreto se conformaron con el voto del señor don Manuel, y en su vista la Junta acordó que se llame para el miércoles veinte $y$ siete del corriente.

\section{2}

\section{1/Mayo/10. Canaria.}

Junta con asistencia de D. Manuel del Río y D. Isidoro Romero, regidores perpetuos, D. Ignacio Díaz, diputado.

D. Manuel del Río dice que, habiéndose comunicado a la Junta por diferentes ocasiones y no poderse haber evacuado el asunto y acordado en las Juntas de 14 y 16 de abril por la no asistencia del señor síndico, aunque se le ha citado, es de parecer que instando $\mathrm{D}$. Isidoro como cosa pendiente y que tiene que retirarse al campo el que se resuelva, es su dictamen que está muy pronto a tratar en la materia, pues no ha dejado de venir cuando se ha llamado pero que, ignorando si puede dar su parecer sin asistencia de todos los señores, lo 
suspende hasta otra Junta, protestando no sean de su cuenta y cargo el no despacho de los pobres que aguardan por las licencias.

D. Isidoro dijo que, habiendo sido convocado para esta Junta por dos veces con expresión de haberse de tratar en ella del asunto importante que está pendiente a instancia del señor síndico, se han frustrado unas veces por no ocurrir este, y otras por faltar los señores D. Ignacio Díaz y D. Andrés Barreto. Y siguiéndose de esto grave perjuicio al común y que en la de hoy ha opuesto el señor D. Manuel del Río la duda que se advierte en su propuesta, es de dictamen que, bajo los apercibimientos que haya lugar, se convoque por dicho señor a Junta para las 4 de la tarde este día, protestando todos los daños y perjuicio que se siguiesen al público y a los pretendientes detenidos para las licencias de maderas.

También hace protesta D. Ignacio Díaz.

Se acuerda convocar junta para la tarde de este día.

\section{3}

\section{1/Mayo/10. Canaria.}

Junta a las once menos cuarto con asistencia de D. Manuel del Río y D. Isidoro Romero, regidores perpetuos; D. Ignacio Diaz y D. Andrés Barreto, diputados; y D. Sebastián de Quintana, síndico personero.

Para poder tratar sobre lo expuesto por el guarda de Tejeda que se ha visto este día, se acordó se copie una y otra exposición, que son las siguientes:

Muy ylustres señores. Don Antonio Thobar y Falcón, su[b]teniente de milizias provinciales y alcalde real del lugar de Texeda, ante vuestra señoría como mejor corresponda, digo que esta Junta de Montes se sirvió nombrarme por theniente de guarda maior de los Pinales desde el año pasado de mil setecientos ochenta y ocho, señalándome de renta anual cient pesos, además de los caídos que tamvién se sirvió vuestra señoría señalar por las asistencias a los cortes de maderas que ocurriesen, que fue ocho reales vellón por dia. En esta suposición y la de que no huviese demora en el pagamento de la renta ni mutación en los derechos, deseando asimismo la conservación de montes y veneficio común a que solamente aspira la savia intención de vuestra señoria, he puesto todos quantos medios me [h]an sido posibles para el desempeño de mi encargo, a costa de no solo de las pérdidas de mis labores, de que únicamente me sostengo, sino también grangeando inumerables enemistades que [h]an acaerrado la no verdad de una sujeción que jamás se [h]abia experimentado.

Por lo que respecta a lo primero, aunque e devengado dos años cumplidos desde octubre pasado no a tenido ningún efecto, sovre que espero que vuestra señoria se sirva dar una pronta providencia a fin de que de pronto se me satisfaga lo vencido, pues me hallo con urgencia de repetir por ello; $y$ asi espero que en el caso de no haverse resuelto por el Consejo (de donde según tengo entendido se experaba la determinación del ramo que se habian de sacar estas rentas), por pronto remedio y de donde más adaptable sea se me contribuia al menos con la del primero año. En quanto a lo segundo, e observado que a instancia de los pretendientes de maderas los [h]an modificado de tal modo que en 
el dia ba el guarda a servirles de valde, al que menos tres dias, porque expecifican las lizencias que no ex[clediendo el corte de tres pies de árbol no se le contribuia con cosa alguna, y exediendo se la paguen ocho reales por el señalamiento. Sobre esto es de haser presente a vuestra señoria que el guarda tanto trabajo tiene para señalar un árbol como para señalar sinquenta, porque una ves de conducido al sitio donde se executa el corte le es indiferente señalar muchos o pocos, pero al paraxe más inmediato que lo baia a haser tiene dos dias de camino, otros a tres y hasta seis dias de hida y vuelta, con que vea vuestra señoría si esto se le paga con los ocho reales; y eso en caso que ex[c]eda de los tres pies de árbol, pues no ex[c]ediendo nada parece que se la paga, bien que de uno u otro modo se le perjudica a menos que se le contribuía con los ocho reales que primeramente se le señalaron por dia. No puede menos que con la actividad que vuestra señoría sela la conservación y existencia de montes estar bien informado de los espacioso, dilatado y asperosidad de los Pinales, que a no haver tenido un hixo llamado Ygnacio Thovar, que me [h]a ayudado a alternar en las salidas $y$ otras ocasiones que a bido necesidad a un mismo tiempo concurro yo a un paraxe y él a otro para dar cumplimiento y que ninguno se quexe. Me parece (y con más motivos en el año presente por razón de este otro empleo) que teniéndolo a bien vuestra señoría con alguna renta aunque moderada que se le señalara se le despachara titulo, bien de teniente de guarda en propiedad o al menos para las ausencias. Esto lo propongo por parecerme arreglado y conforme, salvo la mexor determinación de vuestra señoría. Y sobre todo lo demás que llevo propuesto, creo no dexarán de resolver de pronto, pues además de los atrasos que tengo experimentados sin haver reembolsado cosa alguna e desembolsado para los escribanos de Junta dies y ocho reales de plata por las instrucciones o capitulos que sirven de gobierno, en cuia virtud, suplico a vuestra señoría se sirva proveer en todo como llevo pedido, que es merced con justicia. Antonio Tobar Falcón Betancurt.

\section{$\backslash$ Exposición del guarda del Pinal Don Antonio Tobar, que son dos/}

Se haze presente a la Junta por el guarda don Antonio Thobar la ninguna necesidad que [h]ay de remplantar el Pinal a causa de que en las partes por donde se [h]a pegado fuego a resultado una producción tan copiosa de los mismos pinos que no se pueden numerar; y si considera necesario, asi para la subsistencia y crecimiento de éstos, el que se nomvrem un guarda por la parte de Tirajana, otro por La Aldea y otro por Artenara u Agaete, a fin de que estos celen en razón de que los ganados, mayormente cabrios, no apasten por aquellas partes de la nueba creación, y que para ello se le señale dónde deben ejecutarl,o sin perjuicio como tamvién que dichos guardas cuiden de que no se extraiga madera por aquellas partes, porque aunque se ponga a cuidado de los alcaldes $y$ sindicos personeros estos halla por quán inposible puedan cumplir a causa de que primero irian a su utilidad y trabajo que no a lo que quan no les tiene quenta; y que haviendo sujetos destinados para dicha guarda, lo mirarán de otro modo y resultará el veneficio debolver el Pinal al ser que en lo antiguo tenía, y esto dentro de pocos años. E ygualmente que se haga presente a la Junta haber rezivido la orden de catorze de marzo, a que dará cumplimiento a la mayor brevedad, lo que aún no ha practicado por lo invernoso de los tiempos y no haver carboneros en este partido. 
La Junta acordó que el señor síndico diga lo que se le ofrezca.

Exposición del síndico personero sobre los replantos y no estar de acuerdo en que no se hagan porque así lo obliga la real cédula de 1748 , y en quanto al número de carboneros es de sentir se acuerde con arreglo a lo que sobre ello ha informado la Real Sosiedad en razón de que se mande hazer el carbón fuera de lo poblado de la Montaña, sin convenir en que se fixe número por el perjuicio que podrá resultar al público, en que esto vendrá a ser casi un estanco con cuio motivo pedirán más caro por él que lo que actualmente lo están vendiendo, al menos que se fixe presio determinado a la arroba.

D. Manuel del Río es del dictamen del síndico y se conforma en todo con él.

D. Isidoro Romero hace su exposición:

En punto de carboneros está persuadido que de no llevarse adelante el número y corhartación señalada que se a acordado con dictamen de la Real Sociedad por orden del superior tribunal de la Real Audiencia, protesta desde haora a vuestra señoria que no sean de su cuenta todos los daños que se siguieren de consentir la multitud de sinquenta y seis que avia capaces de asolar la Montaña en poquísimo tiempo, no considerando por motibo suficiente para consentir tal mal el que el presio del carbón se suba, pues hay remedio de ponerle postura en caso de que se ecsediesen los carboneros de los presios medios y regulares según su trabajo y el actual valor de la leña.

D. Ignacio Díaz y D. Andrés Barreto se conforman con lo expuesto por el sindico.

La Junta acuerda se tenga por determinación la exposición del síndico, y que para su aprobación se consulte con la Real Audiencia.

Se presentaron dos memoriales para sacar madera del Pinar:

- Uno de Juan Manuel Domínguez, vecino de Teror, para la fábrica de una casa alta con su cocina en Teror, necesitando quince jubrones, diez tosas, treinta soleras y una cumbrera.

- Otro de José Pérez, vecino de Telde en Valsequillo, para una casa, cocina $\mathrm{y}$ alpendre, solicitando doce tosas, ocho vigas, veinticuatro jubrones y sesenta tijeras.

Se conceden las licencias.

Memorial de D. ${ }^{a}$ Ana Monteverde pretendiendo que se le reforme en los términos que antes se hacian las licencias para la saca de madera del Pinar. Sse acordó no ha lugar por ahora hasta que resuelva la Real Audiencia sobre este asunto.

\section{4}

1791/Junio/4. Canaria.

Junta con asistencia de D. Manuel del Río y D. Isidoro Romero, regidores perpetuos, y D. Andrés Barreto, diputado.

En esta Junta que fue citada a pedimento de D. Isidoro Romero, este dijo que el 1 del corriente se le hizo saber un auto de la Real Audiencia, con fecha del mismo día, por el escribano de cámara D. José Pérez en que, a resultas de 
la consulta hecha por la Junta en razón de los derechos que se deben devengar de los árboles que se cortan para replantos y fondos de esta Junta, y también para cortar el número de carboneros, se dignó mandar que esta Junta entregase original de los dictámenes que se citaban en la consulta de la Real Sociedad Económica de Amigos del País sobre la materia, y que en adelante la Junta se abstuviese de remitir testimonios, ciñéndose nada más que a representaciones reducidas en consultas. Se acordó se guarde y cumpla y se entreguen a dicho escribano de cámara los papeles que pide dicho tribunal de la Real Sociedad Económica.

Memorial de Francisco José Betancurt, vecino de Telde, para sacar del Pinar doce tosas, siete vigas, cuarenta jubrones, ochenta soleras y cuarenta tijerones para la fábrica de dos casas según la lista del oficial de carpintería. Se concede la licencia.

\section{5}

\section{1/Julio/27. Canaria.}

Junta con asistencia de D. Isidoro Romero, regidor perpetuo, y D. Andrés Barreto, diputado, porque D. Manuel del Río y D. Ignacio Díaz se hallan en el campo.

Memorial de D. Ventura Ruiz de Bustamante, contador de la real renta del tabaco, vecino de esta ciudad, para sacar del Pinar veinticinco tosas, doce vigas, seis vigotes, sesenta y cuatro jubrones y cuarenta soleras cuadradas para la fábrica de su casa en la parte de Triana; se concedió la licencia.

\section{6}

\section{1/Julio/30. Canaria.}

Junta con asistencia de D. Isidoro Romero, regidor perpetuo, y D. Andrés Barreto, diputado, porque D. Manuel del Río y D. Ignacio Díaz se hallan en el campo.

Memorial de D. José Luján, alcalde del lugar de Guía, para sacar de la Montaña de Doramas doscientas latas, cincuenta horcones y cincuenta cargas de rama para la celebración de las comedias que se celebran el día de Nuestra Señora de Guía en el mes de agosto de este año. Se concede la licencia para sacar las doscientas latas y cincuenta horcones, con tal que las hayan de guardar para los dos años siguientes, en los cuales no se concederá; y en cuanto a la rama, se le permite sacar treinta cargas de las bajas y que en el desbroce se cortarían para limpiar los árboles, absteniéndose de cortar árbol tierno, asistiendo a ambos uno de los guardas.

\section{7}

\section{1/Agosto/11. Canaria.}

Junta con asistencia de D. Manuel del Río y D. Isidoro Romero, regidores perpetuos, y D. Andrés Barreto, diputado.

Se vio un oficio de la Real Sociedad Económica de Amigos del País de esta isla que exhibió el señor D. Isidoro Romero, y es la siguiente: 
En Junta celebrada el dia de ayer se ha dado parte a la Sociedad de que para la quema de cal para la cañería que se está construyendo con designio //316rto de conduzir a los pilares del público agua de la de fuentes de Morales, se ha pensado en cortar leña del Monte, y como la Sociedad ha limpiado a sus propias expensas todos los asebuches se proyecta cortar dicha leña de los lentiscos a pretesto de limpiarlos de las ramas que tengan contra el suelo.

La Sociedad, que conoze muy bien que esa limpia, lexos de aprobechar a los lentiscos les ha de perjudicar porque estos son unos árvoles rastreros, cuya frondosidad y lozanía consiste en estenderse sobre la tierra sin elevarse en pie o tronco como los azebuches y demás árboles, acordó hacer oficio a vuestra señoría para suplicarle tenga a bien comunicar esta noticia a la Junta de Montes a fin de que se sirba reponer la orden que haya dado sobre el capitular y no permita que se toque a los lentiscos durante la veda absoluta en que está dicho Monte hasta su total restablecimiento, pues los expresados lentiscos no necesitan ni les //316vto aprobecha la limpia o poda, según está comprobado con la experiencia $y$, por tanto, la sociedad no lo ha hecho como la haria si fuera conveniente; $y$ antes por el contrario, hasta se ha prohibido el que se coja su granilla para aceite por solo el inconveniente del perjuicio que causaban los que hacian esa recolección lastimando los retoños y renuevos, y con el mismo objeto se ha privado que se cazen conejos con perros en dicho Monte, porque para correrlos apalean los referidos lentiscos a cuya maleza y espesura se acojen ahuyentados los conejos.

La Sociedad, que ha consumido muchos marabedises en las siembras y plantios, poda y desbroce de los acebuches del Monte con el fin de restablecer esta útil alhaja del público, que le es tan necesaria, considera que sería retardado el fin que se ha propuesto si se permitiera el destroce de los len//317rtotiscos, que han de ser (si se conservan) los que más pronto han de ponerse en estado de que se haga uso de su leña, la cual consiste en la multiplicación de esas ramas y troncos de que se les quería limpiar para la quema de cal.

En esta inteligencia espera la Sociedad que la Junta, enterada por vuestra señoría del contenido de esta, se sirva impedir el destroce de los lentiscos, sea con el pretexto de la quema de cal u otro cualquiera; y que dando a ese fin las órdenes convenientes tenga la bondad de participárselas para satisfación de su celo patriótico. Nuestro Señor, que a vuestra señoría guarde muchos años. Canaria y agosto, nuebe de mil setecientos noventa y un años. Don Josef de Viera y Clavijo, director.

Se acordó que, por medio de D. Isidoro, se conteste dicho oficio manifestándole que esta Junta, firme en la resolución de sostener la veda rigurosa del Monte Lentiscal, no ha variado su dictamen desde aquella época, y se le asegura no es autora de las órdenes que se han dado de desbrozar dicho Monte para la quema de cal ni para otro fin; por lo que conjetura procederá del señor corregidor, contra lo cual la Junta no tiene autoridad.

Memorial de D. Isidoro Romero, con memorial y lista del carpintero Domingo Sánchez, pidiendo sacar del Pinar una tosa, una cumbrera, un pie derecho de siete varas y treinta tijeras cuadradas de tres varas y media para la fábrica de una casa en el lugar de la Vega. Se concede la licencia. 


\section{8}

\section{1/Agosto/17. Canaria.}

Junta con asistencia de D. Manuel del Río y D. Isidoro Romero y Zevallos, regidores perpetuos, y D. Andrés Barreto, diputado.

Esta junta fue convocada para ver un auto de la Real Audiencia que le hizo saber el receptor Fernando de Quintana a resultas de una representación de la Real Sociedad Económica de Amigos del País en que se opone al desbroce del Monte mandado hacer por el señor corregidor. Y habiéndose tratado y conferido, se acordó se informe a dicha superioridad que esta Junta no ha intervenido ni tenido parte en el desbroce que dice la Real Sociedad Económica, de cuya novedad fue la primera noticia que tuvo el oficio que le pasó dicha Real Sociedad Económica en 9 del corriente, y sigue sobre las necesidades para hacer la cañería.

\section{9}

\section{1/Agosto/26. Canaria.}

Junta con asistencia de D. Manuel del Río y D. Isidoro Romero, regidores perpetuos, y D. Andrés Barreto, diputado.

Memorial de D. Diego de Lara, vecino de esta ciudad, para sacar del Pinar una quilla, dos rodas, una pieza de costones, cinco piezas redondas, nueve piezas abiertas, de mayor a menor, siete piezas de astas dobles, cuatro planas, cinco piezas de jinchimientos, cinco piques de mayor a menor, seis curligas, cuatro bancos y siete latas para la fábrica de un barco de dos rodas para fletes de estas islas. Se acordó conceder la licencia.

\section{0}

\section{1/Octubre/11. Canaria.}

Junta con asistencia de D. Manuel del Río y D. Isidoro Romero, regidores perpetuos, y D. Andrés Barreto, diputado.

Se vio una representación hecha a la Real Audiencia por la Junta de la Real Sociedad Económica de Amigos del País en 27 de septiembre de 1791 sobre los cortes que se hacen en la Montaña de Doramas anualmente por los vecinos de Guía y Gáldar para las fiestas, y la licencia que concedió la Junta y lo perjudicial que es para el Monte, a resultas de la cual la Real Audiencia dicta un decreto en 30 de septiembre de 1791 para que la Junta informe en el plazo de dos dias.

Y se trató sobre los motivos que habían dado lugar para la concesión de la licencia y que, por ser asunto de poca consideración, no necesitaba de consulta a la Real Audiencia, todo lo cual se pase a dicho tribunal.

\section{1}

\section{1 / Noviembre/12. Canaria.}

Junta con asistencia de D. Manuel del Río y D. Isidoro Romero, regidores perpetuos, y D. Andrés Barreto, diputado. 
Memorial de D. Fernando de Quintana, vecino de esta ciudad, para sacar de la Montaña de Doramas doscientas cargas de leña para el gasto de su casa. Y se concede la licencia con tal que se hayan de cortar en la parte de la Montaña que está abierta, absteniéndose de ejecutarlo en la parte que está vedada, sacándose de retales y gajos secos, como se previene en las ordenanzas, asistiendo uno de los guardas y trayendo el maestre que la condujese a esta ciudad papel del guarda de ser aquella leña la misma que consta ser de esta licencia.

\section{2}

\section{$1791 /$ Noviembre/29. Canaria.}

Junta con asistencia de D. Isidoro Romero, regidor perpetuo, y D. Andrés Barreto, diputado.

Se presentaron por el escribano menor del cabildo siete denuncias que le había entregado Antonio Rodriguez, sobreguarda puesto por la Real Audiencia en el Monte Lentiscal:

- De José Sánchez, vecino de las Cuevas de la Atalaya, cortando hierba y acebuches el 22 del corriente a quien se le embargaron bienes.

- A Francisco Diego, vecino del pago de San José en la Vega, cortando hierba y acebuches del Monte, y se le embargaron bienes.

- A Juan Martín, vecino del pago de San José, en el 12 del corriente estaba cortando hierba y acebuches nuevos y se le embargaron bienes.

- A Manuel de Sosa, vecino de esta ciudad en el Sabinal, en el 22 del pasado estaba en el Monte con una yunta haciendo leña, las cuales se le embargaron.

- José Marrero, que estaba en dicho Monte con 6 reses vacunas y una jumenta, lo que acaeció el 22 del pasado.

- A Mateo Rivero, del mismo vecindario en San José, quien el 12 del corriente estaba cortando hierba y llevaba acebuches nuevos.

- A Pedro Santa Ana, vecino del pago de San José de la Vega, en el día 12

del corriente estaba cortando hierba y llevaba acebuches y se le embargó una yunta.

Se acordó suplicar al corregidor proceda contra los contenidos como corresponda.

\section{3}

\section{1/Diciembre/9. Canaria.}

Junta con asistencia de D. Ignacio Díaz y D. Andrés Barreto, diputados, porque D. Manuel del Río no puede asistir por la enfermedad de su madre y D. Isidoro porque pide la licencia.

Memorial de D. Isidoro Romero pidiendo licencia para sacar de la Montaña de Doramas dieciséis jubrones de acebiño de seis varas de largo para la fábrica de una casa que necesita para techarla. Se concede la licencia con tal que se saque de la parte que no está vedada y se haga con uno de los guardas. 


\section{4}

\section{1/Diciembre/13. Canaria.}

Junta con asistencia de D. Isidoro Romero, regidor perpetuo, D. Ignacio Díaz y D. Andrés Barreto, diputados.

Memorial de Antonio Cubas, con lista jurada, para sacar del Pinar ciento veinte piezas dobles de madera de ligazón, roda, codaste, dos gambotas, yugo, timón, pala de tajamar, doce cintas, cuatro mesas, sobrequilla, veinte bao, contracodaste, dos dormidos, dos cabestrantes, seis palos de tablas para bancos y seis trancaniles, necesaria para la fábrica de un barco de la costa de pescadería. Se concede la licencia pero que se haga donde hay más espesura de árboles, y no en las orillas del Pinar.

\section{5}

\section{2/Enero/19. Canaria.}

Junta con asistencia de D. Isidoro Romero, regidor perpetuo, y D. Andrés Barreto, diputado.

D. Isidoro Romero hizo presente una representación hecha a la Real Audiencia por los señores de la Junta de la Real Sociedad Económica de Amigos del País, en vista de la cual se proveyó auto de la Real Audiencia.

Ex[celentisi]mo señor. La Real Sociedad Económica de Amigos de esta ysla, que con protección de vuestra excelencia disfruta de tres años a esta parte la satisfación de exercitar su zelo patriótico en promober a beneficio público el restablezimiento del Monte Lentiscal, no puede menos que hacer presente a vuestra excelencia que ve muy a peligro de malograrse todo quanto está adelantado en fuerza del exacto cumplimiento que ha dado a su encargo el guarda elexido por vuestra excelencia, Antonio Rodriguez, zelando y defendiendo el dicho Monte $y$ a beneficio de los quantiosos plantios, siembras, trasplantos, //328rto podas y desbroces que ha executado este real cuerpo desde diziembre de ochenta y ocho y ha continuado sucesivamente en todos los i[n]viernos hasta el presente, en que se están siguiendo los trasplantos con dirección e intervención de los socios comisionados y a expensas de este real cuerpo, que ha invertido en ellos más de quatro mil reales, cuyos beneficios que tienen al Monte en un estado ventajosisimo de restablecimiento y mejora se inutilizarán sin duda si falta la mencionada custodia, la qual no puede verificarse completamente en tanto que se seguerá sostener la nueva regla y máxima que sigue de algún tiempo a esta parte la Junta de Montes de no admitir las denuncias del guarda sin que las acredite a lo menos con un testigo.

Esta condición que desautoriza al guarda no sirve sino para hacer más insolentes a los infractores, porque no siéndole posible a aquel el caminar continuamente asociado de otra persona que atestigue los daños de los que son sorprehendidos en el acto de contravenir a las órdenes y vandos promulgados para la veda del Monte, queda ilusorio su zelo e infructuosa su vigilancia, pues enterados ya de que al guarda no se le admiten las denuncias que no acredita con testigos //328vto llegan los contraventores al exceso de burlarse de él diciéndole que si ha de denunciarlos al dia siguiente lo haga en aquel sin experar al de mañana. 
Una avilantés semejante no puede menos que trastornar todo el buen orden que es necesario para contener a los vezinos en el miedo del guarda y en la obcerbancia de las órdenes publicadas para la veda y la custodia del Monte, sin lo qual se destruirá todo lo que está grangeado hasta aqui con la absoluta prohivisión de apastar ganados, de cortar leña y arrancar yerva, prohivisión llevada hasta el último punto por guarda Rodríguez y de que a resultado la renovación del dicho Monte, la procreación de sus semillas y la produción de quantos plantones y simientes extrañas se le han puesto a mano.

Está ya comprobado y bien acreditado con la experiencia lo mismo que este real cuerpo tenía expuesto en repetidas ocasiones; esto es, que el Monte por si mismo es capaz de reproducirse y poblarse de árboles con solo libertarle de los ganados, y que estos más bien que las hachas eran los que le tenían en el deplorable estado a que se hallaba reducido en fines del año de //329rto ochenta y ocho, como que estaba muy cerca de su total destruc/c]ión, porque aún en el caso de que las hachas arruinaran toda su arboleda antigua las cepas, raizes y semillas serian bastante para volverle a renovar, siempre que no huviese ganado que deborase su retoñada y naciencias. $Y$ asi se ha visto, pues en los tres años cabales que ha se tiene libre de todo género de ganados ympidió la siega de la yerva, con la qual se talaba la numerable porción de arbolitos que todos los años produze la semilla de los árboles grandes, se ha reproduzido con tal ferosidad que estos se hallan vestidos de nuevo y la tierra poblada de otros pequeños que se han trasplantado oportunamente a costa de este cuerpo patriótico.

La práctica inconcusa que se ha observado siempre en orden a las denuncias de los guardas de Montes ha sido el de [pre]ferir a su declaración jurada, y por ella se ha procedido contra los defraudadores o contraventores denunciados, $y$ no sabemos que hasta [ah]ora se haya cansado la atención de este superior tribunal con recurso alguno en que los reos denunciados tratasen de falsificar la acusación que el guarda les ha hecho de oficio; antes por el contrario, sabemos que //329vto confesaban su delito sin calumniar las legalidades de aquel ministro público. De otro modo no seria posible que un hombre solo tuviera guardado y defendido el Monte, y precisamente se necesitarian muchos guardas que anduviesen en quadrillas zelando el Monte, lo qual no es dable, mayormente quando para uno solo no hay salario fixo, gratificación ni gages que le indemnicen de su trabajo digno, la verdá, de premio y remuneración.

Bajo este concepto desea la Sociedad que no se altere la costumvre de que se admitan al guarda del Lentiscal todas las denuncias que haga juradas por razón de su oficio con expresión de testigos en las que los huviere, y sin que la falta de estos inutilise las demás; y que el escribano ante quien haga el expresado juramento extienda todas las denuncias como por declaración, sin que se obligue al guarda a la formalidad de presentar en papel separado las denuncias de cada reo, con lo que se le recarga el costo de pagar al que le ha de escribir dichos memoriales, pues el mismo escribano podria después certificar con la distinción //330rto o separación que sea necesaria lo que haya depuesto el guarda contra cada contraventor en particular para formalisarle su causa, pues que de resultas ha de exigir los derechos que devenga en cada una, porque de 
obligar al guarda a tales formalidades no se saca otra cosa que poner trabas y obstáculos al castigo y al excarmiento de los culpados, en cuya atención:

Suplica y espera la Sociedad que vuestra excelencia se sirva mandar que la declaración jurada del guarda en la conformidad que antedicha sea bastante como hasta aqui para que se proceda contra los denunciados en el caso de haver sido aprehendidos o hallados por él en el acto del fraude o contravención a lo mandado, sin testigos que lo comprueben y acrediten y que, enjuiciados los reos, se les imponga la pena establecida para su delito si no comprueban su inocencia, a todo fin de que se contenga de este modo la inobediencia y no quede ilusorio el oficio del guarda, de lo que resultarian graves perjuicios a la buena custodia del Monte para su aumento y mejoras, en que tanto se desvela este real cuerpo por su adhesión al bien público. Nuestro Señor guarde a vuestra excelencia muchos años. Ciudad real de las Palmas en Gran Canaria, a diez y nueve de diziembre de mil setecientos noventa $y$ un años. Don Josef de Viera $y$ Clavijo, director. Don Josef de la Rocha, vicecensor.//330vto Don Pedro Russell, secretario. Ex[celentisi]mo señor presidente, regente e oydores de la Real Audiencia de Canaria.

Acuerdo de la Audiencia en 24 de diciembre de 1791, en el cual ordena que la Junta de Montes, tomando razón de las denuncias que se le presenten por el guarda del Monte Lentiscal, las pase al corregidor, quien se arregle a lo que se manda en el capítulo 27 de la real instrucción de 7 de diciembre de 1748 , y baste que el guarda haga sus denuncias por comparecencia, jurando ante cualquier escribano o el que la Junta señale.

Vista la representación y el acuerdo de la Real Audiencia, se acordó nombrar por escribano por ante quien se hagan las denuncias, no solo del Monte Lentiscal sino de los demás, a D. José Martel como segundo escribano del Ayuntamiento, a cualquier hora que compareciere, tomando razón del testigo o testigos que citare para su comprobación, lo que pasará al presidente de la Junta para que convoque al resto y dar curso a las denuncias.

También se acordó se pague al escribiente D. Nicolás del Castillo los 5 pesos que del producto del desbroce se sirvió la Real Audiencia mandar se le diese en cada año por el trabajo de citar a los señores de esta Junta, y es por el año pasado.

Memorial de D. José Tovar, presbítero vecino de Gáldar, para sacar de la Montaña de Doramas cien latas para levantar los parrales que tiene. Se acordó conceder la licencia con tal que el corte sea en los más viejos y retuertos que no sirvan para utilidad.

\section{6}

\section{2/Enero/30. Canaria.}

Junta con asistencia de D. Isidoro Romero, regidor perpetuo, y D. Andrés Barreto, diputado. Fueron citados D. Manuel del Río y el síndico personero, pero no asistieron por causa de algunos embarazos.

Memorial de D. José Martín Déniz y Ramos, presbitero vecino de Arucas, pidiendo licencia para sacar del Pinar treinta y cinco vigas y seis tosas de tea 
para la fábrica de una casa. Se acordó concederla siendo el corte en la parte abierta, y no de la vedada.

\section{2/Febrero/15. Canaria.}

Junta con asistencia de D. Manuel del Río y D. Isidoro Romero, regidores perpetuos. D. Andrés Barreto, diputado, y el síndico personero fueron citados, pero no acudieron.

El escribano menor de Cabildo demostró la certificación de 13 del corriente que contiene una denuncia dada por uno de los guardas de la Montaña de Doramas, D. Francisco Dominguez, sobre usurpación de terrenos en la Montaña en los confines de las tierras de la data de San Lázaro, en los que tiene de renta la viuda de Antonio Mateo, violando los mojones. Y contra Francisco Guerra y Francisco Navarro, por haberse introducido en desmontar parte de la pertenencia de dicha Montaña.

También demostró diez denuncias dadas por Antonio Rodríguez, guarda del Monte Lentiscal, contra Francisca Cabrera, vecina de Las Cuevas; Juan Galván, vecino de la ciudad; la mujer de Mateo Cabrera; Francisca Lorenzo, mujer de Juan de León; un hijo de José Díaz; Mateo Cabrera, vecino de Las Cuevas de los Frailes; Agustín López, vecino de la Vega; contra José Sánchez, vecino de La Atalaya; contra Manuel Cabrera, de Las Cuevas de los Frailes; y contra Antonio Estévez, vecino de La Atalaya. Se acordó pasen al corregidor para que castigue a los infractores.

Se presentaron cuatro memoriales:

- Uno de Pedro Tovar, para sacar del Pinar veinte tosas, quince vigas y setenta jubrones para la fábrica de una casa en esta ciudad. Se concede la licencia.

- Otro de D. Francisco Tomás Hernández, guarda mayor de la Montaña de Doramas, para sacar de ella quinientas latas y quinientos horcones. Se concede solamente doscientas latas y doscientos horcones, y estos sean de los más viejos y retuertos inútiles de no poder para árboles útiles, y sea con intervención de uno de los otros guardas.

- Otro de D. Pedro Acedo, presbítero vecino de esta ciudad, para sacar del Monte Lentiscal dos gatos y dos portezuelas y tierra y arena, la madera para un lagar y la tierra y arena para la fábrica de una casa. Se concede, con tal que asista el guarda para señalar el sitio donde se ha de sacar la tierra y para el corte de las dos portezuelas y gatos.

- Otro de José Agustín Pérez, vecino de esta ciudad, queriendo comprar cuatro acebuches de los caídos que se hallan en el Monte Lentiscal. Se acordó conceder la licencia con tal que el guarda Antonio Rodríguez asista al ajuste de los árboles y a la saca de ellos. 


\section{8}

\section{2/Febrero/28. Canaria.}

Junta con asistencia de D. Manuel del Río y D. Isidoro Romero, regidores perpetuos.

Se acordó que se pase testimonio del auto proveído o acuerdo de la Real Audiencia de 24 de diciembre de 1791 al señor corregidor por medio de D. Andrés Barreto para su inteligencia.

Memorial de D. Juan José de Quesada, vecino de Gáldar, para sacar de la Montaña de Doramas doscientas latas para sus parrales. Se concede la licencia, con tal que las hagan sacar de las más viejas y retuertas que no sirvan para árbol útil, y que sea con asistencia de cualquiera de los guardas.

Antes de levantarse la sesión, se acordó que en ausencia o enfermedad del escribano segundo del Cabildo, D. José Martel, que se señaló por la Junta de Montes para autorizar las denuncias, las pueda autorizar igualmente el escribano mayor de Cabildo que es o fuere.

Memorial de D. Mateo Aguilar, vecino y presbítero de Telde, pretendiendo sacar del Monte Lentiscal dos nabos y dos templas para un agar ${ }^{14}$ por tener necesidad de estas piezas. Se concede, con tal que sean de los árboles caídos, con asistencia del guarda Antonio Rodríguez.

\section{9}

\section{2/Marzo/2. Canaria.}

Junta con asistencia de D. Manuel del Río y D. Isidoro Romero, regidores perpetuos, y D. Andrés Barreto, diputado.

Se pretendieron dos memoriales para sacar madera del Pinar:

- Uno de D. Manuel Padrón, regidor perpetuo de esta isla, para sacar veinte jubrones y treinta piezas entre tosas y vigas, para la fábrica y composición de unas casas en esta ciudad.

- Otro de D. Vicente Quintana, vecino de Tejeda, para sacar cinco cumbreras, tres tirantes, trece vigas cuadras, doce palos, doscientos jubrones y trescientas cuatro tijeras, para la fábrica de unas casas en Tejeda.

Se conceden las licencias, con tal que sea en paraje abierto y no en el vedado, y se entienda en lo más poblado y no en las orillas.

100

1792/Marzo/17. Canaria.

Junta con asistencia de D. Manuel del Río y D. Isidoro Romero, regidores perpetuos, y D. Andrés Barreto, diputado.

Se vio una carta de D. Antonio Tovar, guarda de los Pinares, en que pide que la Junta le haga pagar los salarios de su renta, que no se le ha pagado desde que entró a ejercer su oficio. Y en vista de que Su Majestad y su real Consejo, a quien se dio noticia para la aprobación de dicha renta del caudal

14 (sic) 
de propios, no se ha dignado resolver, siga por ahora el dicho guarda en los términos que hasta aquí ha hecho en oficio y con los emolumentos de las licencias, y de no tenerse en cuenta acuda a la Junta y haga renuncia en forma.

Memorial de D. Francisco del Castillo Ruiz de Vergara, coronel de milicias y alférez mayor de esta isla, para sacar de la Montaña de Doramas doce bomberos, veintiséis palos de boca, veinticuatro palas de encerrar y doce docenas de latas. Se acordó conceder la licencia con tal que no echen a perder árbol útil y las buras ${ }^{15}$ sean de las más inútiles y los palos y demás de la misma forma y con asistencia del guarda.

Se presentaron diecisiete denuncias por el sobreguarda puesto por la Real Audiencia: D. Francisco Tomás, vecino de Arucas en la costa de Layraga, contra José Cruz, Cristóbal Suárez, José Melián, Cristóbal Almeida, Salvador el herrero, D. Ignacio Melián, Francisco Medina, Francisco de la Fe, Mateo Navarro, José Guía, Pedro González, Josefa Marrero, todos ellos vecinos de Moya; y Andrea Marrero, Rita Medina, Blas Miguel, Brigida Suárez, Francisco Medina, todos ellos vecinos de Arucas, por estar cortando leña en la Montaña de Doramas. Se acordó pasen al corregidor para que les dé curso

\section{1}

\section{2/Abril/ 11. Canaria.}

Junta con asistencia de D. Manuel del Río y D. Isidoro Romero, regidores perpetuos, y D. Andrés Barreto, diputado.

Memorial de Pablo Martín, vecino de Moya, para sacar de la Montaña de Doramas treinta tijeras, una cumbrera, un pie derecho, ocho jubrones, dos umbrales y un palo para las puertas, con su lista jurada del oficial, para la fábrica de una casa en Moya. En atención al atraso que tiene la montaña y escasez de árboles gruesos de donde poder sacarse piezas gruesas para edificios, se acordó conceder la licencia solo para que se puedan sacar los ocho jubrones; y para las demás piezas saque la competente licencia para el Pinar, y ha de sacar dicha madera con intervención de los guardas.

El escribano mayor de Cabildo dio cuenta a esta Junta óomo el señor corregidor le había prevenido no autorizase licencia alguna de corte de madera que concediese esta Junta sin que antes ésta le hubiese pasado testimonio del auto del superior tribunal en que se sirve excluir a dicho señor corregidor de la intervención en ella porque, aunque tenía noticia del citado auto, no se le había hecho saber y estaba enterado de que dicha superioridad no le privaba de tomar los derechos que le estaban asignados y tiraba por costumbre inmemorial. En cuyos términos, considerando esta Junta estar inmediatamente subordinada a la superioridad de la Real Audiencia y que de su Real Acuerdo ha recibido la facultad de concederlas sin que hasta el presente se haya mandado cosa en contrario por dicho tribunal, se acordó que el presente escribano autorice sin excusa alguna en la licencia concedida o que se concediese en adelante, pena de veinte ducados que se les impone a la voluntad del superior tribunal.

15 (sic) 
102

1792/Abril/ 17. Canaria.

Junta con asistencia de D. Manuel del Río y D. Isidoro Romero, regidores perpetuos, y D. Andrés Barreto, diputado.

Memorial de Francisco Domínguez, vecino de Teror, pidiendo sacar del Pinar doce jubrones, un palo para puertas, una cumbrera y treinta tijeras, de la parte de Pajonales para la fábrica de una casa en Teror. Se acordó conceder la licencia en los términos que va extendida.

\section{3}

1792 / Abril/23. Canaria.

Junta con asistencia de D. Manuel del Río y D. Isidoro Romero, regidores perpetuos, y D. Andrés Barreto, diputado.

Memorial de D. Juan Bernardo de Cala para sacar del Pinar dos vigas de prensa para un agar ${ }^{16}$ de diez varas, diez vigas, quince tosas, sesenta jubrones, cuarenta tijerones y treinta soleras para la fábrica de una casa en Telde. Se concedió la licencia en los mismos términos que las demás.

Memorial de D. Agustín de la Rocha, regidor perpetuo de esta isla, para sacar de la Montaña de Doramas el desbroce de ramas, altabacas, ramazón y demás maleza para quemar un horno de cal en la parte de Firgas para la fábrica de una casa. Se acordó conceder la licencia interviniendo el guarda de la parte de Firgas, con tal que la leña ha de ser de zarzas, retales, altabacas y demás maleza y de ninguna manera de árbol alguno de pie, ni nuevo ni viejo, bajo la pena que se hará desbaratar el horno y 20 ducados de multa.

104

1792/Mayo/10. Canaria.

Junta con asistencia de D. Manuel del Río y D. Isidoro Romero, regidores perpetuos, y D. Andrés Barreto, diputado.

Se presentaron seis memoriales:

1. Juan Sánchez Castrillo, vecino de Guía, para sacar del Pinar cuarenta jubrones, veinte vigas, veinte palos de solladio y ciento veinte tijeras para la fábrica de tres casas, dos terreras y una alta.

2. D. Isidoro Romero para sacar del Pinar veinticinco jubrones, una cumbrera, un pie derecho, treinta y seis tijeras y cinco tosas para la fábrica de una casa.

3. D. Lorenzo Zanqui, vecino de esta ciudad, para sacar del Pinar una quilla, una roda, codaste, yugo, ocho palos de cintas, veintiún palos de latas, sobrequilla, cien palos de ligazón, veintiuna docenas de tablas y dos palos de arbolar para la fábrica de un barco de setenta palmos de quilla.

Y en su vista, se acordó conceder las licencias para el Pinar.

4. D. Francisco Ascanio, presbitero vecino de esta ciudad, para sacar de la Montaña de Doramas sesenta tijeras, diez lumbrales y las varas para el

16 Sic. 
techo. Se concede la licencia para las tijeras y varas y diez lumbrales y no para los jubrones.

5. D. Lorenzo Zanqui, vecino de esta ciudad, para sacar de la Montaña treinta cargas de duelas de viñático para hacer unos barriles. Se concede la licencia, con tal que sea de los cepones de viñático contados con asistencia del guarda.

6. D. Domingo Henríquez, vecino de Teror, para sacar de la Montaña de Doramas el desbroce de zarzas, altabacas, ramazón y demás maleza para quemar un horno de cal en la parte de Guadalupe, para componer una casa. Se concede la licencia interviniendo el guarda de Teror y la leña sea de zarza, altabacas y demás maleza y no de árbol alguno de pie, ni nuevo ni viejo, bajo la pena que se hará desbaratar el horno y 20 ducados de multa.

\section{5}

\section{2/Mayo/21. Canaria.}

Junta con asistencia de D. Manuel del Río y D. Isidoro Romero, regidores perpetuos, y D. Andrés Barreto, diputado. Citado el síndico personero que no asistió.

Nicolás del Castillo, que hace de portero, entró y juró haber citado a los señores presentes y al síndico, que se excusó. D. Manuel del Río preguntó a Nicolás del Castillo por qué motivo no había citado en las antecedentes sesiones de la Junta al síndico, a lo que contestó que al principio del año lo había ejecutado por algunas veces pero que últimamente, después de muchas citaciones. le había manifestado el susodicho que para licencias de madera no le citase sino que las expidiese la junta, lo que le mandó al escribano le certificase y de haber pasado así.

El presidente de la Junta hizo presente un auto de la Real Audiencia de 19 del corriente, para la que fue convocada esta Junta, por el cual se sirve mandar a la Junta que informe sobre el contenido del recurso que hizo a dicha superioridad el Ayuntamiento de esta ciudad con motivo de la licencia que concedió esta Junta al capitán D. Lorenzo Zanqui para que pudiese cortar en los Pinares la madera necesaria para la construcción de un bergantín que destina para el tráfico y comercio entre esta isla y La Habana. Sobre lo cual se acordó se obedece y que, para darle cumplimiento, se haga dicho informe a la mayor brevedad por el señor D. Isidoro Romero en la forma siguiente:

Excelentísimo señor. En Junta de Montes que se zelebró en la mañana de este dia en acuerdo y obedezimiento del superior mandamiento de vuestra excelencia de diez y nueve del corriente, que se sirvió expedir con motibo del recurso echo a vuestra excelencia por el personero y Ayuntamiento de esta ciudad en razón de la lizencia de corte de madera en los Pinares que concedió dicha //339rto Junta al capitán don Lorenzo Zanchy para la construcción de un bergantín para el tráfico de América, mandando que dicha Junta informase sobre ella, se acordó que yo, a su nombre, espusiese respectivamente a vuestra excelencia que la dicha Junta concedió la referida licencia al capitán don Lorenzo Zanchy, porque le constava que este se havía connaturalizado por vasallo de Su Magestad el rey nuestro señor (que Dios guarde) con las formalidades prevenidas en 
sus reales cédulas renunciando su patria, sus leyes y la prote[c]ción de su enbajada, sujetándose en todo y por todo a las que saquen en nuestra España. Que en esta virtud, deviendo gozar todos los privilegios y esenciones que goza la nación española, no havía motivo para denegarle su pretención, como no se le coharta a ningún vezino natural desta ysla que solicita lizencia para la construcción de buques como sea para fomentar el comercio y beneficio de ella, semejante al que se propuesto el referido Zanchy de abrir directamente comunicación entre esta ysla y la de La Habana navegando a ella y retornando a esta, proporcionando la salida de los caldos y otros frutos y manufacturas del pais en fomento de la agricultura, industria y comercio activo y del pasivo por el retorno de azúcares, cuero, cera y otras producciones de aquellos dominios, con lo que también se moverán otros a su imitación haciendo construir más barcos para en/san]char dicho comercio, de que se seguirá indubitablementre a esta ysla la proporción de disfrutar sus vesinos industriosos las utilidades que gozan los de la ysla de Thenerife por dicha vía.

Que está más distante de creer la Junta de que //339vto por solo el referido corte se destruian los pinares de la ysla, pues para ello era necesario desentenderse de los muchos y repetidisimos que se están [h]asiendo para la construcsión de varcos nuebos y compocisión de los biejos, en que por proceder los dueños de ellos [d]espóticamente a las talas sin solicitar (si no es uno otro) la competente lizencia de la Junta se hacen dolorosos desmontes en donde mejor les acomoda para sus haorros sin el buen orden y método que por su oficio deven hacer observar los guardas con arreglo a las órdenes e instruc/cjiones que se les tiene dada por dicha Junta, los quales daños sí son en realidad dignos de lástima porque reducirán los montes en poco tiempo a su total desolación. No lo siendo menos de reparo el que el celo del Ayuntamiento y su personero no se haia movido a reclamar estos excesos que an mirado con total indiferencia, esxitándose solo en ocasión que se pretende el corte con lizencia y en que por sus resultas se va [a] aumentar el comercio de esta ysla aAmérica, de que ha caresido desde que faltaron los rexistros de la permisión, y esto no a costa de caudal público sino de un particular que se espone a sacrificar a una suerte incierta cantidades considerables que si se pierden se malogran de su cuenta.

Si los dichos montes, excelentísimo señor, están en el atraso que se espresa por dicho Ayuntamiento y personero, no es culpa ni por omisión de la Junta sino del caballero corregidor y sindico personero, pues viendo estos las gruesas partidas de leña y maderas que se desenvarcan //340rto en esta playa, ni el primero usando su jurisdic/c]ión contenciosa las impide ni castiga a los culpados ni el segundo ha pedido en cumplimiento de su cargo lo conveniente al remedio alguno que la Junta como a vuestra excelencia consta ha acordado y ha pedido en uso de su jurisdicción económica y gubernatiba quanto ha jusgado por conveniente a su conservación, aumento y replantos [...].

Si la Junta que se celebró para la otorgación de dicha lizencia tiene la nulidad que reclama el personero, él tiene la culpa, según resulta del certificado que con el devido respeto incluio a vuestra excelencia, a cuio superior mandato me someto. 


\section{6 \\ 1792/Junio/8. Canaria.}

Junta con asistencia de D. Manuel del Río y D. Isidoro Romero, regidores perpetuos, y el síndico personero D. Juan de Cala.

Memorial de D. Pedro Cabrera, hacedor de rentas decimales de esta isla, para sacar del Pinar sin señalamiento de puerto ni término en que se deba sacar, ciento veinte piezas entre tosas y vigas para la obra de la catedral que se está haciendo. Se acordó conceder la licencia siendo cierto que es la para la obra, y que el corte no sea en las orillas ni donde haya despoblado sino donde haya espesura.

\section{7}

\section{2/Junio/12. Canaria.}

Junta con asistencia de D. Manuel del Río y D. Isidoro Romero, regidores perpetuos, y D. Andrés Barreto, diputado. Citado el síndico personero que no asistió.

D. Manuel del Río mostró un auto de la Audiencia, fechado en Canaria a 24 de mayo de 1792, por el cual los señores presidente regente e oidores de la Real Audiencia dijeron que, habiendo visto el expediente promovido en razón de la licencia concedida por la Junta de Montes a D. Lorenzo Zanqui para la construcción de un bergantín con madera del Pinar, por ahora se levanta la suspensión de corte de madera y corra la licencia que por la Junta se concedió a D. Lorenzo Zanqui para la construcción del bergantín, otorgando la fianza de no enajenarlo que propuso la Real Sociedad. Que la Junta no conceda iguales licencias sin consultarlo antes con este tribunal y cuide del replanto correspondiente a este corte, según lo previenen las instrucciones, para lo cual recoja el importe de maravedies que está asignado en el reglamento a cada árbol cortado, todo lo que ejecute con intervención de la Sociedad y la ciudad nombre sin dilación al diputado que falta a la Junta como es de su obligación.

Se acordó se obedece y se le dé debido cumplimiento.

Igualmente acordó se haga presente, por medio del señor D. Manuel del Río, con testimonio de este acuerdo, el que a esta Junta le parece más útil para asegurar el fondo de dichos maravedies y menos gravoso para los que intentaren y pretendiesen las licencias el que, según la cantidad de madera que pidan así sean los derechos que exhiba; es, a saber, que el que pida licencia para cortar, por cada diez tosas, veinte jubrones y cincuenta tijeras pague 8 reales de vellón; que el que baje de ahí, pague 5 reales de vellón, y por la de una lancha 15 reales vellón. Los cuales derechos exhiba precisamente al mayordomo de propios, sin cuyo requisito de poner este el pago en la licencia firmada de los señores de la Junta no pueda el escribano de ésta firmarlas ni el guarda darles cumplimiento.

Haviendo observado la Junta de que el motibo más poderoso de la decadencia y atraso de los montes depende principalmente del abuso y libertad que tienen los que fabrican barcos, los que comercian en madera y los que traginan en la leña de sabina, de cortar y sacar las dichas maderas de los montes y pinales sin la competente lizencia desta Junta e intervención de los guardas, y 
que esto está espresamente prohivido en la real cédula de montes, en el citado reglamento y en varios acuerdos particulares de la misma Junta; y que si no se impide este desorden por ello, ya que el señor corregidor, a quien compete el castigo destos exesos, los tolera, llegará el caso del total exterminio de los Pinares y Montes de savinal de Amurga, se acordó que el presente escribano esté alerta y a las primeras partidas que decemvarquen de maderas de construcción nabal y terrestre y leñas de montaña y savinas cuios dueños no le manifiesten la lizencia que obtuvieron para ello de la Junta según el término que en ella se le huviese concedido las embargue inmediatamente dando parte de ello con la misma brevedad a la Junta para su govierno, recogiendo las lizencias de las que las tengan para que no se vuelba a usar de ellas dándoles sus pases.

Memorial de José Manuel, vecino de Tejeda, que pretende hacer brea en el Pinar y pide se le conceda licencia. Se le concede, con tal que sea fuera de las orillas del Pinar y con intervención del guarda D. Antonio Tovar, y sea por el término de este año, y los que no tuviesen licencia de los fabricantes de dicha especie ocurran a sacarla porque de lo contrario se les privará.

\section{8}

\section{2/Julio/2. Canaria.}

Junta con asistencia de D. Manuel del Río y D. Isidoro Romero, regidores perpetuos, y los demás señores citados.

El escribano de Cabildo D. José Martel exhibió tres certificaciones que contenian haber pasado a la playa de San Telmo, donde había porción de leña de sabinas, soleras, tijeras y leña de tarajal, y son los siguientes:

- Pedro Pérez, vecino de Gáldar, que condujo a la playa de San Telmo leña de sabina y de tarajal.

- Otro de Blas de Miranda, vecino de la ciudad, que condujo en su barco porción de leña de sabina.

- Otro de José Cerdeña, vecino de Telde, que condujo a la playa de esta ribera porción de leña de sabina, soleras y tijerones.

Toda la dicha leña se embargó y consta de los certificados. Y, en su vista, se acordó pase al señor corregidor para que dé las providencias que corresponda.

\section{9}

\section{2/Julio/5. Canaria.}

Junta con asistencia de D. Manuel del Río y D. Isidoro Romero, regidores perpetuos, D. Andrés Barreto, diputado, y D. Juan de Cala, sindico personero. No concurrió D. Andrés Cabrera.

Habiendo advertido esta Junta que, por haberse olvidado el escribano Vázquez, a quien tocó anotar al margen del acuerdo de 6 de abril de 1791 en que se prohibió el corte de madera de sabina sin la competente licencia, se ha tomado de este pretexto para hacer impunes las contravenciones en esta parte alegando no haberse publicado ni hecho saber en los pueblos ni por los guardas la dicha prohibición, continuando el corte sin el requisito de dicha licencia en grave perjuicio de los montes, que llegarán a su total destrucción si no se 
ataja con tiempo, se acordó que para que no se alegue ignorancia en su punto de tanta consecuencia se suplique al corregidor con el correspondiente oficio por medio de D. Andrés Barreto con testimonio de este acuerdo se sirva mandar fijar carteles en esta capital en que se manifieste dicha prohibición bajo las penas que fueren de ley.

En esta Junta, D. José Martel, escribano de Cabildo, manifestó una representación hecha por el teniente de sobreguarda puesto por la Real Audiencia D. Francisco Tomás Hernández en la Montaña de Doramas:

Muy ylustres señores: Don Francisco Tomás Hernández, guarda mayor nombrado por la Real Audiencia de la Montaña Doramas, vezino de Arucas en la costa de la Ayraga, ante vuestra señoría en desempeño de su encargo hace presente que deseando la conserbación y aumento de dicha Montaña está tocando con la experiencia que estaba caminando a su última desolación, pues los fueristas de los lugares de Arucas, Moya, Firgas, Teror, Guía y Gáldar, validos de dicho fuero entran en ella y la talan para sacar leña en tal conformidad que si por vuestras señorias no se toman algunas providencias para contenerles, pasando al señor governador de armas un oficio a fin de que les contenga, llegará el día que no hayga Montaña y se verán los naturales en la precisión de abandonar la ysla, pues el que representa no puede estorbarles a causa de que validos del fuero de la guerra no hazen caso de sus moniciones y si provara quitarles la hacha y piden se resisten a ello y se expone queriéndola llevar a devido efecto a un lanze sangriento.

Tamvién debo exponer que los carboneros, si se les permite continuar como hasta aqui, acabarán con dicha Montaña, pues no tan sólo la destrosan sin distinción y árboles sino que la ban arando y dejándola en postura de no producir más árboles en aquellas partes donde queman para hacer el carbón. En cuya atención espera el que representa que vuestras señorias den una providencia general que habrase el modo y forma con que deben portarse los fabricantes de dicho carbón para lo subsesivo, imponiéndoles para que lo observen las penas y multas que se tengan a bien. Francisco Thomás Hernández".

Vista la representación, se acordó en lo que concierne al desorden que causan los fueristas militares a su sombra se pase el correspondiente oficio con testimonio de esta representación y acuerdo al gobernador de las armas por medio de D. Isidoro Romero, para que dé las órdenes convenientes en los cuerpos de milicias de esta isla para que se contengan observando lo mandado por Su Majestad. Y por lo que toca a contener los inconvenientes y perjuicios que causan a la Montaña de Oramas los carboneros talando y desarraygando del todo los árboles de modo que no podrán reproducirse por sus raízes, en lo adelante se acordó que, no obstante que en la superioridad de la Real Audiencia hay expediente pendiente en la materia que se lleva por consulta que opinaron de diferente modo de pensar los indibiduos que la componian entonces, siendo de dictamen unos de que se pusiese número determinado de carboneros y los demás con el señor personero de otro parezer, desengañada esta de que no habrá otro medio de cortar de raíz tan graves perjuicios que es el de poner en execución el acuerdo que selebró esta ciudad en cavildo en que acordó prohivir absolutamente el que se hiciesen carbón en la Montaña de Oramas permitiéndolo solamente en los Pinares, en estos en donde no hiziesen perjuicio, se haga 
presente este su parecer a la superioridad de la Real Audiencia a fin de que, dignándose mandar unir el testimonio deste acuerdo y representación que se incluirá con oficio del señor don Andrés Barreto a los dichos antezedentes que se hallan en el acuerdo, se sirba resolver lo que fuese de su mayor agrado, suplicándole asimismo respetuosamente, sin ser visto hazer instancia, tenga ha vien el resolber igualmente el asunto pendiente en dicha superioridad sobre los derechos que deban pagar los que pretendan corte de madera por careser esta Junta de fondos, asi para costear los replantos como para dar alguna gratificación a los guardas que lo merezcan por el cumplimiento de su obligación.

110

\section{2/Julio/9. Canaria.}

Junta con asistencia de D. Manuel del Río y D. Isidoro Romero, regidores perpetuos, D. Andrés Barreto, diputado. Citados D. Andrés Cabrera y D. Juan de Cala, síndico personero.

Se presentaron dos memoriales por el escribano menor del cabildo:

- Uno de Andrés Rusell, pidiendo sacar del Pinar cuarenta tosas, sesenta vigas, cien jubrones y cien tijeras como consta de la lista jurada del oficial para la fábrica de casa. Sse concede con tal de estar a lo que se dignase resolver la Real Audiencia en cuanto a los derechos que han de pagar por cada árbol que se corte en virtud de la representación que le ha hecho esta Junta y de que se manifieste la dicha licencia al desembarcarse en esta ciudad la dicha madera.

- Otro de José Suárez, vecino de Telde, para sacar del Pinar una bancada de leña de tea y retal de la que otros han dejado de que han cortado árboles. Se concede con tal que dicha licencia la ha de manifestar a esta Junta traída que sea la dicha bancada.

\section{1}

1792/Julio/17. Canaria.

Junta con asistencia de D. Manuel del Río y D. Isidoro Romero, regidores perpetuos, D. Andrés Barreto, diputado.

Se presentaron dos memoriales:

- Uno de D. Carlos Navarro, vecino de Telde, para sacar del Pinar doce tosas, cuarenta jubrones, ciento cincuenta tijeras y diez vigas, que consta de la lista para la fábrica de una casa en Telde.

- Otro de D. Francisco del Castillo, alférez mayor y regidor perpetuo de esta isla, para sacar de la Montaña de Doramas veinte jubrones, dos madres y cuatro pies derechos para la fábrica de una casa que tiene en la hacienda de la Costa de Layraga.

Se acordó conceder las licencias, con tal de estar a lo que se dignase resolver la Real Audiencia sobre los derechos que han de pagar por cada árbol que se corte en virtud de la representación que tiene hecha esta Junta, y manifiestan las licencias a los guardas para que estos pongan el visto de estar cortada la madera. 


\section{2}

\section{2/Julio/23. Canaria.}

Junta con asistencia de D. Manuel del Río y D. Isidoro Romero, regidores perpetuos, D. Andrés Barreto, diputado.

Se presentaron dos memoriales:

- Uno de Vicente del Toro, vecino de Tejeda, para hacer brea en el Pinar de Pajonales, jurisdicción de Tejeda. Se concede con tal que dicha brea se haga de los retales y desperdicios de los cortes en lugar o sitio separado de bosque o árboles y donde el guarda señale; y si la licencia no se presenta, se procederá contra el susodicho.

- Otro de D. Juan Bravo, para sacar del Monte Lentiscal una corza y cuatro puyones para arrastrar una piedra de molino. Se acordó informe el señor D. José Arbonies si hay árbol alguno donde poderse sacar la corza y puyones del Monte respecto hallarse dicho señor con la limpia de dicho Monte.

\section{3}

\section{2/Agosto/1. Canaria.}

Junta con asistencia de D. Manuel del Río y D. Isidoro Romero, regidores perpetuos, D. Andrés Barreto, diputado, y D. José Gómez, síndico personero.

Memorial de José Domingo, vecino de La Aldea de San Nicolás, para sacar del Pinar una barcada de leña de sabina que tiene cortada antes que saliera la prohibición y que, sin la licencia de la Junta, no la puede traer a la ribera de esta ciudad. Atento a lo que señala, se acordó conceder la licencia, con tal que a su desembarque manifieste esta licencia de esta Junta al guarda para que presencie si es cierta estar cortada la dicha barcada de leña.

\section{4}

\section{2/Agosto/6. Canaria.}

Junta con asistencia de D. Manuel del Río y D. Isidoro Romero, regidores perpetuos, D. Andrés Barreto, diputado. Citado el sindico personero.

Se presentó un pedimento de denuncia por el escribano D. José Martel, entregado por el guarda del Pinar D. Antonio Tovar, sobre la quema de dicho pinar por la parte de Pajonales. que es así:

Muy ylustres señores. Don Antonio Tobar, guarda de los Pinares de esta ysla, ante vuestra señoria, como mejor corresponda parezco y digo: Que en cumplimiento de mi encargo no puedo menos de hacer presente que, en el veinte $y$ quatro de julio próximo pasado, se incendió el pinar de Pajonales que estaba ardiendo por espacio de quatro dias, infiriéndose de ellos los perjuicios que son notorios. Que el causador de este incendio, según distintas notizias que [h]e adquirido, fue Francisco Lorenzo, vezino del lugar de Texeda, donde dizen Chimberil o Hoya de la Vieja, pero nunca huviera tenido tanto fomento el fuego como se experimentó si el alcalde real de Texeda, cumpliendo como devía con su hobligación, huviese tratado de apagarlo y cortarlo. Pero sucedió tan al contrario que el dia dicho veinte y quatro de dicho mes por la mañana pasó dicho alcalde por la parte que estaba ardiendo el Pinar con dirección a una función que se celebraba en una hermita de Santiago, y lejos de tratar impedir el que 
se dilatase siguió su destino, mandándome tan solamente a la noche un recado para que yo fuese [a] apagarlo, a cuyo acto concurrió el día siguiente. Y, en fin, con atención a que siempre por estos tiempos suceden estos incendios cometidos por los infractores, tal vez por falta de un castigo exemplar denuncio al Francisco Lorenzo y demás que resulten reos en dicho acto para que vuestra señoria se sirba imponerles las penas a que se han [h]echo acreedores. Por tanto, suplico a vuestra señoria se sirba en vista de lo expuesto probeer como en esta denuncia se contiene que es justicia. Antonio Thobar Falcón".

Se acordó se saque testimonio del artículo de la última instrucción al guarda que habla sobre incendios de montes, se una a esta denuncia y se pase inmediatamente por el presente escribano al corregidor para que le dé el correspondiente curso.

\section{5}

1792/Agosto/11. Canaria.

Junta con asistencia de D. Manuel del Río y D. Isidoro Romero, regidores perpetuos. Citados D. Andrés Barreto, diputado, y el síndico personero.

Se presentaron dos memoriales:

- Uno de Juan Sánchez Betancurt, vecino de Telde, para sacar del Pinar trescientas cargas de leña de sabina para con una poca que tiene cortada hacer una barcada, doscientas soleras y una cumbrera, todo de retal.

- Otro de Francisco José Betancurt, vecino de Telde, para sacar del Pinar ciento cincuenta cargas de leña de sabina, ciento cincuenta soleras, veinte jubrones y dos vigas, todo del desbroce que otros han cortado.

Se acordó conceder licencia para la leña de sabina que tienen cortada y no para que corten la que pretenden. También se le concede licencia para las soleras pero no para el resto, con tal que las soleras sean de retales. Y trayendo lista jurada de oficial de carpintero, se dará providencia y dicha licencia se presentará al guarda, quien pondrá su toma de razón.

Se presentó el informe hecho por D. José Arbonies, como comisionado por la Real Sociedad de esta isla para el desbroce y limpia del Monte Lentiscal, a un memorial dado por D. Juan Bravo, vecino de esta ciudad, en junta de 23 de julio de este año, en que pretendía sacar de dicho Monte un corzón y cuatro puyones. Y en vista de dicho informe, se acordó no ha lugar a la corza y se conceden los puyones con tal de que se proporcione coyuntura en el desbroce asistiendo el guarda.

\section{6}

\section{2/Agosto/23. Canaria.}

Junta con asistencia de D. Manuel del Río y D. Isidoro Romero, regidores perpetuos, y D. Andrés Barreto, diputado.

Se presentaron dos memoriales:

- Uno de D. Bartolomé Morales, para sacar del Pinar ciento cincuenta tijeras, cincuenta jubrones y once tosas para la fábrica de una composición de atrás. Se concede la licencia, con tal de estar a lo que se dignase resolver la 
Real Audiencia en cuanto a los derechos que han de pagar por cada árbol que se corte en virtud de la representación que le ha hecho esta Junta y de que se manifieste la dicha licencia al desembarcarse en esta ciudad la dicha madera.

- Otro de D. ${ }^{a}$ Leonor Alvarado, vecina de esta ciudad, para sacar de la Montaña de Doramas doscientas cargas de leña para el abasto de su casa. Se concede la licencia con tal que el guarda señale el puesto de árboles secos de donde se han de cortar las doscientas cargas y tomará razón de la madera.

\section{7}

\section{2/Septiembre/3. Canaria.}

Junta con asistencia de D. Isidoro Romero, regidor perpetuo, y D. Andrés Barreto, diputado. D. Manuel del Río, en el campo, y citado el síndico personero.

Se presentaron dos memoriales:

- Uno de Blas de Miranda, vecino de esta ciudad, para sacar del Pinar cien palos de ligazón, planes, aposturas y brazos, seis manos de cintas, un timón, quilla, dos rodas, doce latas, veinte palos para tablado, dos palos para arbolar con sus vergas, y la madera para una lancha y composición de otra, cien tijeras, doce vigas y treinta jubrones, una cumbrera y doce palos para solladio, según la lista presentada y jurada por él como oficial de carpintero de rivera, que es la madera del desbroce que dejó el capitán Zanqui del barco que cortó en dicho Pinar. Se acordó conceder la licencia que ha de manifestar cuando traiga la madera que sea de retal.

- Otro de Diego Martín Mayor, vecino de Telde, para sacar del Pinar una barcada de leña de sabina que tiene cortada para traer a esta ribera; se concede la licencia, con tal que a su desembarque manifieste esta licencia de esta junta al guarda para que presencie si es cierta estar cortada la dicha barcada de leña.

Se añade otro memorial de Francisco Sánchez, vecino de Telde, pidiendo licencia para sacar una barcada de leña de sabina que se le concedió con tal que la ha de manifestar a esta Junta luego que venga a esta playa, y del resto de su pretensión no hay lugar.

\section{8}

\section{2/Octubre/8. Canaria.}

Junta con asistencia de D. Isidoro Romero, regidor perpetuo, y D. Andrés Barreto, diputado. D. Manuel del Río en el campo.

Se presentaron dos memoriales:

- Uno de D. Antonio Betancurt, para sacar de la Montaña de Doramas doscientas cargas de leña para el abasto de su casa y quemar aguardiente. Se concede con tal que la licencia la ha de presentar al guarda de la Montaña para que señale el sitio y ponga la toma en razón y traída a estas playas. La manifestará a esta Junta. 
- Otro de Juan Rodríguez el Pájaro, vecino de Telde, para sacar del Pinar una barcada de leña de sabina, de la cual tiene cortada una poca y de la demás para cortarla. Se concede la licencia para la que tiene cortada y lo que pretende cortar sea de retal o troncos de las sabinas ya cortadas y no de otra manera, y dicha licencia se presentará al guarda para la toma de razón.

- Otro memorial presentado por Manuel Medina, vecino de Telde, para sacar del Pinar media barcada de leña de sabina y cortar otra poca para hacer la barcada. Se concedió la licencia para traerla y cortar de los gajos más gruesos de las ramas de las sabinas pero no derribarlas por el tronco, dejando las más delgadas para que estén vivas.

- Otro memorial de D. Antonio del Castillo, vecino de esta ciudad, para sacar del Pinar doscientos jubrones cuadrados, veinte tosas y quince vigas, todo madera de tea, para la fábrica de una casa en esta ciudad. Se concede la licencia con tal de estar a lo que se dignase resolver la Real Audiencia en cuanto a los derechos que han de pagar por cada árbol que se corte, en virtud de la representación que le ha hecho esta Junta y de que se manifieste la dicha licencia al desembarcarse en esta ciudad la dicha madera.

Haviendo entendido la Junta de que, con el motibo de estarse recoguiendo la baga en la Montaña de Oramas, se están haciendo por los que la toman muchos destrozos desgajando árboles y cortando los nuebos por evitar trabajos, se acordó se escriba por el presente escribano cartas a los guardas de de dicha Montaña encargándoles no permitan se tome dicha baga sin estar presentes, prosediendo a denunciar inmediatamente y procesar a los que la fueren a tomar [h]aciendo dichos perjuicios, haciéndoles responsables, como los hace, la Junta a dichos guardas de todos los daños que se verificasen por su omisión como por no celar los cortes en lo que se les advierte mucho descuido; pues save la Junta se están sacando maderas verdes y varias sacas de maderas sin esperimentar el que se haga una denuncia, deviendo entender que de no cumplir con su respectiba hobligación se daba parte a la superioridad de la Real Audiencia de sus descuidos para la providencia que haia lugar.

Habiéndose entendido que José Suárez con dos compañeros, que son Francisco Alejandro y Juan Hernández, a quien se concedió licencia para sacar del retal una barcada de leña de tea de los retales la han llevado a Santa Cruz, se dé parte al corregidor por el escribano con testimonio de este acuerdo para que se proceda a hacer la competente averiguación.

\section{9}

1792/Octubre/24. Canaria.

Junta con asistencia de D. Isidoro Romero, regidor perpetuo, y D. Andrés Barreto, diputado.

Se presentaron dos memoriales:

- Uno de Simón Jorge, vecino de La Aldea de San Nicolás, para sacar del Pinar de Pajonales treinta jubrones, veinte vigas, veinte vigotes y cuarenta tosas para la fábrica de una casa de alto y bajo y otro para sacar retal para traer a esta playa. Se concede la licencia con tal de estar a lo que se dignase 
resolver la Real Audiencia en cuanto a los derechos que han de pagar por cada árbol que se corte, en virtud de la representación que le ha hecho esta Junta y de que se manifieste la dicha licencia al desembarcarse en esta ciudad la dicha madera.

- Otro de Juan Candelaria, vecino de Telde, para sacar del Pinar cien cargas de retal de sabina de los troncos o de tea y para traer cincuenta cargas de horcones. Se concede la licencia para que sea la barcada de leña de retal de tea y no de sabinas, y de lo que otra manera hiciese se dará por decomiso la leña, y se presente la licencia al guarda del pinar para que tome razón de la barcada de leña y traída a esta playa se presente a esta Junta.

\section{0}

\section{2/Noviembre/7. Canaria.}

Junta con asistencia de D. Manuel del Río y D. Isidoro Romero, regidores perpetuos, y D. Andrés Barreto, diputado.

Memorial de Ildefonso de Santa Ana, vecino de esta ciudad, para sacar del Pinar de Pajonales cincuenta tosas, sesenta jubrones y veinte vigas para la fábrica de una casa y composición de otra. Se concede la licencia con tal de estar a lo que se dignase resolver la Real Audiencia en cuanto a los derechos que han de pagar por cada árbol que se corte, en virtud de la representación que le ha hecho esta Junta y de que se manifieste la dicha licencia al llegar a la ciudad con el visto bueno del guarda.

Se presentó un pedimento por el escribano D. José Martel de D. Francisco Tomás Hernández, guarda mayor de la Montaña de Doramas, diciendo que en este día se le acaba de manifestar que distintos sujetos se emplean en tomar la baga de la Montaña de los laureles, y en su consecuencia manda se reciba información de los contraventores. Se acordó que se esté a lo proveído en Junta de 8 de octubre del corriente año, cumpliendo con su obligación delatando a los contraventores.

\section{1}

1792/Noviembre/14. Canaria.

Junta con asistencia de D. Isidoro Romero y, regidor perpetuo, y D. Andrés Barreto, diputado. Citado el síndico personero.

Se presentaron tres memoriales:

- Uno de D. Diego de Cabrera, mayordomo dela cofradia de Nuestra Señora del Rosario de Arucas, para sacar del Pinar de Pajonales cincuenta tosas, treinta vigotes, cuarenta vigas, seis cumbreras, ciento cincuenta jubrones, cuarenta tijerones y doscientas tijeras para la fábrica del camarín y un retablo en la parroquia de dicho pueblo de Arucas. Se acordó conceder la licencia con tal de estar a lo que se dignase resolver la Real Audiencia en cuanto a los derechos que han de pagar por cada árbol que se corte, en virtud de la representación que le ha hecho esta Junta y la nota puesta del guarda a su pie.

- Otro de Francisco José Betancurt, vecino de Telde, para sacar del Pinar una barcada de leña de retal de tea y troncos de sabina y doscientas soleras 
y dos cumbreras, estas para una casa, y la leña para vender. Se concede la licencia para la barcada de leña de retal de tea, soleras y las dos cumbreras, pero no para la sabina; y la licencia deberá presentar al guarda para que tome su razón.

- Otro de D. Domingo Galdós, vecino de esta ciudad, para sacar de la Montaña de Doramas madera para una lancha y composición de otra. Se acordó no haber lugar sacarla de la Montaña de Doramas y se le concede para el Pinar.

Se presentaron por el guarda Francisco Domínguez, vecino de Teror, ocho denuncias de distintos sujetos de vecinos de Fontanales, los Palmitales de Guía, del barranco del Pinal y de Teror por atentar contra la Montaña de Doramas. Se pasen al corregidor para que les dé curso.

122

1792/Noviembre/23. Canaria.

Junta con asistencia de D. Manuel del Río y D. Isidoro Romero, regidores perpetuos, y D. Andrés Barreto, diputado.

En esta Junta exhibió el escribano D. José Martel una denuncia dada por Antonio Rodríguez, guarda del Monte Lentiscal, de haber encontrado un burro en él comiendo hierba, que no se sabe de quién es. Se acordó pase al corregidor para que le dé curso.

Memorial de D. Francisco Peniche, vecino de esta ciudad, para sacar del Pinar una barcada de tea del desbroce que hay alli. Se concede la licencia

\section{3}

\section{2/Diciembre/5. Canaria.}

Junta con asistencia de D. Isidoro Romero, regidor perpetuo, y D. Andrés Barreto, diputado. Citado D. Manuel del Río.

Se presentaron tres memoriales, uno de D. Lorenzo Sanchi, otro de D. Domingo de Galdós, vecino de esta ciudad, y otro de José Martín Domingo, vecino de La Aldea de San Nicolás. Los dos primeros pretenden sacar de la Montaña de Doramas madera para fabricar dos lanchas para el tráfico de la costa, y la de Sanchi para el tráfico a Indias, y el de La Aldea una barcada de leña de tea de retal. Se acordó que Miguel Farias y Blas de Miranda, maestros del oficio de carpinteros de ribera, informen bajo juramento si es cierto no poder ni deber hacerse con la correspondiente firmeza y seguridad las lanchas del barco de costa y demás de este porte sin que el costillaje y ligazón interiores sean de madera de montaña, por ser tan delgados respecto del tamaño de la lancha y no tener la fuerza suficiente la madera de pino. Y en cuanto a la de José Martín, se concede la licencia con tal que sea de retal y no de otra manera.

\section{4}

1792/Diciembre/10. Canaria.

Junta con asistencia de D. Manuel del Río y D. Isidoro Romero, regidores perpetuos, y D. Andrés Barreto, diputado. 
Se presentó el informe hecho por Miguel Farías y Blas de Miranda, oficiales de carpintero de ribera, mandado dar por la Junta en 5 de este mes a resultas de la madera pedida por D. Lorenzo Sanchi y D. Domingo de Galdós:

Dezimos nos Miguel Farias y Blas de Miranda, maestros de carpinteros ribera, que haviéndosenos manifestado por el escribano maior de Cavildo D. Francisco Martinez de Escobar el acuerdo y memoriales dados por don Lorenzo Sanchi y don Domingo de Galdós para que por la Junta se les concediese lizencia para cortar de la Montaña de Oramas madera para lanchas, y que si esta se puede estorbar su corte respecto haverla en el Pinal. Y en cumplimiento de lo mandado, juramos que la madera del dicho Pinal no es suficiente por ser muy vidrienta y que con las lanchas se trabaja más en la manihobra de los barcos, caletas y demás cargas que hacen con ellas, y que por lo propio no es de la subsistencia, como la de la Montaña, por ser madera más recia y tener [h]ebra para la subsistencia de su duración. Y por no saber firmar, rogamos a un testigo que lo hiziera por nosotros. Canaria, y Diziembre, seis de mil setecientos noventa y dos años. Soy testigo, Antonio Abad Vásquez Romero.

Se acordó conceder la licencia que solicitan para la madera de las lanchas con tal que se corte en la parte no vedada de la Montaña de Doramas y de que asista al señalamiento del corte un guarda, y lo mismo al tiempo de sacarse la madera, lo que harán constar los interesados en papel que percibirán de dicho guarda, que manifestarán al tiempo del desembarco en las riberas de esta ciudad.

Memorial de D. Andrés Rusell, vecino de esta ciudad, para sacar de la Montaña de Doramas trescientas cargas de leña para el abasto de su casa. Se concede la licencia con tal que intervenga uno de los guardas en el señalamiento del lugar y se traiga papel del guarda.

Memorial del conde de la Vega Grande para sacar del Pinar doscientos jubrones, cincuenta vigas y cincuenta palos para la fábrica de una casa y composición de otras. Se acordó conceder la licencia con tal de estar a lo que se dignase resolver la Real Audiencia en cuanto a los derechos que han de pagar por cada árbol que se corte, en virtud de la representación que le ha hecho esta Junta y la nota puesta del guarda a su pie.

\section{5}

\section{2/Diciembre/29. Canaria.}

Junta con asistencia de D. Isidoro Romero, regidor perpetuo, y D. Andrés Barreto, diputado.

Memorial de D. José Navarro para sacar de la Montaña de Doramas madera para la fábrica de un barco de Jandia. Se acordó que José Talavera y Blas de Miranda, oficiales de carpinteros de ribera, informen bajo juramento si es cierto no deber hacerse el barco del tráfico de la pesca de Jandia sin que el costillaje y ligazón interior sea de madera de la Montaña de Doramas. 


\section{6}

1793/Enero/3. Canaria.

Junta con asistencia de D. Manuel del Río y D. Isidoro Romero, regidores perpetuos.

Se presentó el informe hecho por José Talavera y Blas de 29 de diciembre de 1792 a resultas de la madera pedida por D. José Navarro, el cual es una copia exacta del informe transcrito en Junta de 10 de diciembre de 1792. Se acordó conceder la licencia que solicitan para la madera de las lanchas con tal que se corte en la parte no vedada de la Montaña de Doramas y de que asista al señalamiento del corte un guarda, y lo mismo al tiempo de sacarse la madera, lo que harán constar los interesados en papel que percibirán de dicho guarda, que manifestarán al tiempo del desembarco en las riberas de esta ciudad.

Memorial de Juan Sánchez Castrillo, vecino de Gáldar, para sacar una barcada de leña de retal de tea del desbroce de los cortes que se hacen en el Pinar. Se concede con que la licencia se ha de presentar al guarda para la toma de razón, y al desembarque en esta ciudad se deberá presentar a esta Junta.

Se acordó se paguen al escribano D. Nicolás del Castillo los 5 pesos que, del producto del desbroce, se sirvió la Real Audiencia mandar se le diesen cada año por el trabajo de citar a los señores de la Junta por lo que respecta al año pasado.

\section{7}

\section{3/Enero/30. Canaria.}

Junta con asistencia de D. Manuel del Río y D. Isidoro Romero y Zevallos, regidores perpetuos.

Se presentaron tres memoriales:

- Uno de D. José Suárez, vecino de esta ciudad, para sacar del Pinar de las vegas de Amurga, cien palos de ligazón y demás cosas para un barco del tráfico de la costa.

- Otro de Francisco Monzón, vecino de Telde, para sacar del Pinar de Veneguera cuarenta vigas, veinte tosas, ciento cuatro jubrones, cincuenta soleras, para la fábrica de una casa y demás.

- Otro de Antonio Trensado, vecino de Tejeda, para sacar del Pinar de Mogán y Veneguera treinta tosas, treinta vigas, cien jubrones y cien tijeras para la fábrica de una casa y demás.

Se acordó conceder la licencia con tal de estar a lo que se dignase resolver la Real Audiencia en cuanto a los derechos que han de pagar por cada árbol que se corte en virtud de la representación que le ha hecho esta Junta, y que a su llegada a esta capital hayan de entregar la licencia con el visto bueno del guarda.

Se presentaron dos memoriales:

- Uno de D. ${ }^{a}$ Rita de Medina, vecina de Arucas, y otro de D. Juan Tomás Hernández, vecino de Arucas, para sacar de la montaña de Doramas porción de latas y horcones que son dos mil novecientas. Se acordó no haber 
lugar a la pretensión, y se escriba al sobreguarda puesto por la Real Audiencia para que pase a la ciudad a informar sobre el estado en que se halla la Montaña para acordar lo que se tenga por conveniente.

Se presentaron ocho denuncias por el escribano menor del Cabildo, dadas por el guarda Francisco Domínguez, vecino de Teror. Son todas ellas contra vecinos de Teror, el Palmital, Fontanales sobre todo por estar cogiendo vaga.

\section{8}

1793/Febrero/4. Canaria.

Junta con asistencia de D. Manuel del Río y D. Isidoro Romero, regidores perpetuos.

Se presentaron tres memoriales:

- Uno de D. Francisco Tomás Hernández, vecino de Arucas, para sacar de la Montaña de Doramas dos mil latas y horcones para la fábrica de sus parrales.

- Otro de D. ${ }^{\text {a }}$ Rita de Medina, vecina de Arucas, para sacar novecientas latas y horcones para lo mismo.

Se acordó conceder la licencia para extraer la mitad de sus pretensiones y que sean de los más inútiles dando comisión para el primero a D. Diego de Medina y para el segundo a D. Francisco Tomás.

Otro memorial de Juan Domínguez, vecino de esta ciudad, para sacar del Pinar cincuenta y cuatro palmos de quilla y otros materiales para la fábrica de un barco. Se concede la licencia con tal de estar a lo que se dignase resolver la Real Audiencia en cuanto a los derechos que han de pagar por cada árbol que se corte, en virtud de la representación que le ha hecho esta Junta y que a su llegada a esta capital hayan de entregar la licencia con el visto bueno del guarda

\section{9}

\section{3/Febrero/7. Canaria.}

Junta con asistencia de D. Manuel del Río y D. Isidoro Romero, regidores perpetuos.

Se presentaron tres memoriales:

- Uno de Lucas de Torres, vecino de esta ciudad, para sacar del Pinar cien palos de ligazón y otros materiales para la fábrica de un barco de costa.

- Otro de José Gutiérrez, vecino de esta ciudad, para sacar del Pinar cuatro cumbreras, veinte tosas, cien jubrones y doscientas tijeras para fabricar una casa en dicho lugar.

- Otro de D. Francisco Posadas, presbitero, vecino de esta ciudad, para sacar del Pinar doce tosas y veinte vigas para una casa en esta ciudad.

Se acordó conceder la licencia con tal de estar a lo que se dignase resolver la Real Audiencia en cuanto a los derechos que han de pagar por cada árbol que se corte, en virtud de la representación que le ha hecho esta Junta y que a su llegada a esta capital hayan de entregar la licencia con el visto bueno del guarda. 


\section{0}

\section{3/Marzo/9. Canaria.}

Junta con asistencia de D. Manuel del Río y D. Isidoro Romero, regidores perpetuos.

Se presentaron tres memoriales:

- Dos de D. Antonio Betancurt, uno para cortar madera del Pinar y una barcada de leña de la Montaña de Doramas para el abasto de su casa y fabricar un barco para el trajín de las islas. Se acordó conceder la licencia para la barcada, y en cuanto al barco se concede con tal que sea sin ejemplar, siendo la madera la siguiente: cincuenta piezas dobles de ligazón, treinta palos de apostura dobles, doce latas dobles, barzolas y cabezales dobles dos, tejeles ${ }^{17}$ tres, yugo, aletas, codaste y gambotillas seis piezas dobles, timón, tajamar, sobrecodaste y codaste, roda, durmientes y sobrequilla tres piezas dobles, trancaniles tres palos, quilla y madera para una lancha, treinta palos para tablas y la arboladura correspondiente para el barco; y con tal de estar a lo que se dignase resolver la Real Audiencia en cuanto a los derechos que han de pagar por cada árbol que se corte, en virtud de la representación que le ha hecho esta Junta, y que a su llegada a esta capital hayan de entregar la licencia con el visto bueno del guarda.

- Otro de José Gil para sacar de la Montaña de Doramas, doscientas cargas de leña. Se le concede la licencia.

Se presentaron nueve denuncias por D. José Martel, escribano de Cabildo, contra: Antonio León, por coger vaga en la Montaña de Doramas; Antonio Betancor y su familia, vecino de Guía, por coger vaga; a José Báez, vecino de Firgas, por cortar madera para una lancha; a Cayetano de Sosa y a Juan Bolaños, por coger vaga; otra a Sebastián de León, por coger vaga; otra a Antonio García, hijo de Juan Guerra, de la costa por cortar leña verde; otra a Antonia la gorda ,cogiendo vaga; otra a Juan Blanco, oficial del molino de Firgas, por cortar madera; otra a Juan Bolaños, vecino de Guía, por coger vaga. Se acordó pasen a al corregidor para que se dé cumplimiento y haga justicia con ellas.

\section{1}

$1793 /$ Marzo/23. Canaria.

Junta con asistencia de D. Manuel del Río y D. Isidoro Romero, regidores perpetuos.

Se presentaron dos memoriales: uno de D. Vicente Puertas, para sacar de la Montaña de Doramas cien latas y cien horcones; y otro de Miguel Ruiz para sacar ciento cincuenta latas de la misma Montaña, ambos para los parrales que tienen. Se acordó conceder la licencia, dando comisión al guarda D. Francisco Tomás para que señale y vea lo que se corta.

El señor D. Isidoro Romero dio cuenta de que tiene entendido que la goleta de Antonio Carvajal pasó a un puerto de las calmas de esta isla y cargó leña de tea para el puerto de Santa Cruz y que los sujetos que la fueron a cargar eran José el Ronco, Juan Hernández y Cristóbal el Pájaro, vecinos de Telde. Y

17 (sic) 
se acordó se pase certificación de este acuerdo al corregidor para que lo examine y le dé curso con la mayor brevedad.

Memorial de D. Isidoro Romero para sacar del Pinar cinco vigas, una cumbrera y pie derecho para la fábrica de una casa. Se concede la licencia en los términos propuestos en otras sobre el mandato de la Real Audiencia.

\section{2}

\section{3/Abril/ 17. Canaria.}

Junta con asistencia de D. Manuel del Río y D. Isidoro Romero, regidores perpetuos.

Se presentaron tres memoriales:

- Uno del convento de Santo Domingo de esta ciudad, para sacar del Pinar cien jubrones, ocho tosas, veinticinco tijerones, cincuenta soleras y seis tosas.

- Otro de Antonio de Aguilar, vecino de esta ciudad, para sacar del Pinar ciento cincuenta jubrones, treinta vigas, quince palos y veinticuatro tijeras para la fábrica de unas casas en esta ciudad.

Se acordó conceder las licencias con tal de estar a lo que se dignase resolver la Real Audiencia en cuanto a los derechos que han de pagar por cada árbol que se corte, en virtud de la representación que le ha hecho esta Junta.

- Otro de José Calcines, vecino de Artenara, pretendiendo hacer brea en el Pinar. Se concede la licencia por espacio de un mes con tal que se ha de hacer la brea de los retales y desperdicios o árboles que señale el guarda D.

Antonio Tovar; y en caso de que esta licencia no se presente al guarda, se procederá contra el susodicho.

Por el escribano José Martel se presentaron veintisiete denuncias entregadas por el guarda del Monte Lentiscal Antonio Rodriguez, fundamentalmente por coger hierba e introducir animales. Se acordó se pasen al corregidor para que les dé curso.

\section{3}

\section{3/Abril/24. Canaria.}

Junta con asistencia de D. Manuel del Río y D. Isidoro Romero, regidores perpetuos.

Se presentaron tres memoriales:

- Uno de D. Antonio Zerpa y Romero, regidor perpetuo de esta isla, para sacar del Pinar cuarenta jubrones y quince tosas para su casa.

- Otro de Blas Miranda, vecino de esta ciudad, para sacar del Pinar veinte palos, treinta jubrones, cuarenta tijeras, quince tosas, una cumbrera y un pie derechos.

- Otro de Gregorio Miranda, vecino de Gáldar, para sacar del Pinar treinta piezas de ligazón dobles, veinticinco palos para tablas, dos rodas, quilla y palos de arbolar, con la madera para su lancha, todo ello para un barco del tráfico de estas islas. 
Se acordó conceder la licencia con tal de estar a lo que se dignase resolver la Real Audiencia en cuanto a los derechos que han de pagar por cada árbol que se corte, en virtud de la representación que le ha hecho esta Junta.

Se acordó por los señores de la Junta que no sea de cuenta y riesgo las denuncias dadas en junta anterior el no despacho de ellas, y que se dará cuenta a la Real Audiencia en caso de omisión.

\section{4}

\section{3/Mayo/17. Canaria.}

Junta con asistencia de D. Manuel del Río y D. Isidoro Romero, regidores perpetuos.

Se presentaron dos memoriales: uno de Domingo Sánchez y otro de D. Francisco Cabral, vecinos de esta capital, pretendiendo sacar madera del Pinar para sus obras como carpinteros. Se acordó en el de Cabral que indique para qué obra es la madera o qué sujeto la pide, y en el de Sánchez que, especificando la que necesita para su casa, se dará providencia.

Se acordó que por el presente escribano se haga saber a D. José Martel dé cuenta a primera junta del estado en que se hallan las denuncias dadas por el guarda Antonio Rodriguez en junta del 17 del mes pasado.

Por el escribano mayor de Cabildo hizo presente que los herederos de la acequia de Tafira quieren se les dé certificación de la pretensión de la saca de lajas que se pretendió sacar de dicho Monte para la construcción de dicha acequia en 20 de julio de 1790 . Se acordó se le dé el certificado que pretende.

\section{5}

\section{3/Mayo/24. Canaria.}

Junta con asistencia de D. Manuel del Río y D. Isidoro Romero, regidores perpetuos.

Se presentaron cuatro memoriales: uno del convento de San Francisco, otro Domingo de Gracia Sánchez (ambos pretendiendo sacar madera del Pinar), otro de D. Antonio Betancurt y otro de Salvador de Medina, los primeros vecinos de la ciudad y el último de Guía, estos dos últimos para sacar de la Montaña de Doramas. D. Antonio Betancurt solicitando roda, codaste, quilla, treinta palos de ligazón y cuatro cintas para una lancha, y Salvador de Medina una barcada de leña. Se acordó conceder las licencias en los términos que van expedidas y se da comisión a D. Francisco Tomás, guarda de dicha Montaña.

Y la de Domingo Sánchez es para sacar treinta tosas, diez vigas y cincuenta jubrones para la fábrica de su casa. Y la del convento treinta jubrones, diez tosas, seis medias vigas y ocho tijerones para la fábrica de dicho convento. Se concede las licencias con tal de estar a lo que se dignase resolver la Real Audiencia en cuanto a los derechos que han de pagar por cada árbol que se corte. 


\section{6}

1793/Mayo/28. Canaria

Junta con asistencia de D. Manuel del Río y D. Isidoro Romero, regidores perpetuos.

Se presentó memorial por Ildefonso de Santa Ana, vecino de esta ciudad, para sacar del Pinar una barcada de leña de acebuche y del retal del desbroce que han dejado los cortes que se han hecho en él. Se acordó conceder la licencia con tal que la ha de presentar en esta Junta con la nota puesta del guarda.

\section{7}

$1793 / J u n i o / 7 . ~ C a n a r i a$.

Junta con asistencia de D. Manuel del Río y D. Isidoro Romero, regidores perpetuos.

Se presentaron dos memoriales:

- Uno de Ildefonso de Santa Ana para sacar del Pinar ocho docenas de tablas y una barcada de leña del desbroce para el abasto de su casa y composición de sus barcos. Se acordó conceder la licencia con tal de estar a lo que se dignase resolver la Real Audiencia en cuanto a los derechos que han de pagar por cada árbol que se corte en virtud de la representación que le ha hecho esta Junta.

- Otro de José Mesa, vecino de esta ciudad, para sacar de la Montaña de Doramas cien cargas de leña para el abasto de su casa. Se le concede la licencia presentándola al guarda D. Francisco Tomás, y que éste señale los árboles y presencie el corte, y traída a estas playas la presentará a la Junta.

\section{8}

\section{3/Julio/1. Canaria.}

Junta con asistencia de D. Manuel del Río, regidor perpetuo, y D. Andrés Cabrera, diputado.

Memoria de D. Luis Berneta, vecino de esta ciudad, para sacar del Pinar la madera que consta de la lista jurada del maestro Miguel Farias, que consiste en quilla, sobrequilla, roda, ocho palos de cinta, cuatro gusaldas, cien palos de ligazón, timón y veinte palos para tablas; todo ello, para la composición o reedificación del barco que se naufragó en 27 de junio de este año. Se acordó conceder la licencia con tal de estar a lo que se dignase resolver la Real Audiencia en cuanto a los derechos que han de pagar por cada árbol que se corte en virtud de la representación que le ha hecho esta Junta.

\section{9}

\section{3/Julio/8. Canaria.}

Junta con asistencia de D. Manuel del Río y D. Isidoro Romero, regidores perpetuos, y D. Andrés Cabrera, diputado.

En esta junta, que fue convocada para ver un auto de la Real Audiencia, entró el receptor D. Fernando de Quintana y leyó el auto: 
Canaria, Julio seis de mil setecientos noventa y tres años. Los señores, estando en su Real Acuerdo, dixeron que la Junta de Montes informe a la sala dentro de segundo día si después del auto de veinte y quatro de mayo del año pasado de mil setecientos noventa y dos, en el expediente de corta de maderas concedido a don Lorenzo Zanqui, de nación veneciano, ha concedido otra a este sujeto $u$ a otro que no sea vezino de la ysla sin la consulta en él prevenida.

En su virtud, se acordó guardar y cumplir. Y para darle debido cumplimiento, se saque testimonio del memorial, memoria y acuerdo en que se concedió licencia a D. Luis Verneta, vecino de esta ciudad, fundándose en que la Junta, en la conseción de dicha licencia, no creyó ni cree haverse separado del superior mandato respecto a que la espresada lizencia fue concedida, no a don Lorenzo Zanqui sino a Don Luis Verneta, el qual estando connaturalizado y avesindado en esta ysla a más de diez y seis años y deviendo gozar por esta razón de todas las exepciones y regalias que los demás vasallos de Su Magestad, no se faltava a la condición y limitación puesta por dicha superioridad en quanto a las lizencias que se pidiesen por estrageros, tranzeúntes y no domiciliados. Y aunque quando se pidió la antezedente licencia se creyó ser el único y general interesado el don Lorenzo Zanqui con motibo de la desgracia acaesida, se [h]a descubierto ser el principal interesado el don Luis. Como quiera que la lizencia de madera que se ha pedido no es para fabricar otro nuevo buque sino para reedificar el que se desbarató, renovándole solamente aquella corta porción de maderas que se le inutilisaron por el fondo al tiempo de su desgracia, como se evidencia de la memoria mandada testimoniar, en cuias circunstancias no se podria faltar según la buena hospitalidad y derecho de gentes ni aún a un buque estrangero que casualmente padeciese alguna abería, reputó semejante conseción aunque huviese sido en cavesa del mismo don Lorenzo como insidencia y parte integral de la que por la sala se le avía confirmado. Y solo en este consepto, en que pensó no apartarse en lo más mínimo de lo resuelto por el tribunal, accedió a su consesión, sin que se aya verificado haver concedido otra lizencia de igual naturaleza después del referido auto, el que ha tenido y tendrá muy presente [...].

\section{0}

\section{3/Julio/9. Canaria.}

Junta con asistencia de D. Manuel del Río y D. Isidoro Romero, regidores perpetuos, y D. Andrés Cabrera, diputado.

En esta Junta se hizo presente el decreto de la Real Audiencia, a consecuencia del informe que esta Junta acordó hacer a dicho tribunal en virtud de su mandato, en la que celebró el día de ayer, a resultas de la licencia que concedió a D. Luis Verneta para la reparación del barco nombrado San Luis Gonzaga, que se desgració al tiempo de botarse, que se decía ser de D. Lorenzo Zanqui, de nación veneciano, y que es como sigue:

Canaria, y julio, nueve de mil setecientos noventa y tres. Los señores, estando en su Real Acuerdo dixeron que la Junta de Montes presente dentro del dia la justificación que la haya manifestado don Luis Vernetta acreditando ser 
suio el barco destrosado a el tiempo de votarse a el mar; y pasado y no lo haciendo, suspéndase el corte de madera y recójase la lizencia dada, y sin perjuicio tráiganse las representaciones y expediente refiere dicha Junta.

Se acordó obedecerlo y se informe a la superioridad que los documentos que tuvo presentes para reconocer el derecho que tenía al barco destrozado el D. Luis Verneta fue la insinuación que, como escribano de hipotecas y de la Junta, hizo a esta D. Francisco Martínez al tiempo de leerse el memorial de que a favor de este se habian otorgado dos escrituras por D. Lorenzo Sanqui obligando al crédito de 3.912 pesos el dicho barco, afirmando que dichas escrituras habian pasado una ante él mismo en 20 de enero del presente año y otra ante D. Andrés Cabrera en 4 de mayo del mismo año; que como diputado de esta Junta lo atestó igualmente, con cuyos testimonios no le quedó a la Junta motivo de dudar del interés principal que tenía en el barco D. Luis Verneta. Supuesto ser más la cantidad de la deuda que el valor del barco, no se le ofreció el más mínimo reparo de dudar de la sinceridad de dicha pretensión. Sáquese testimonio de este acuerdo y remítase por medio de D. José Martel al tribunal y su Real Acuerdo.

Memorial de José Flores para sacar de la Montaña de Doramas doscientas sesenta cargas de leña para el abasto de su casa y barcos. Se concede la licencia solamente para cien cargas, con tal que dicho corte ha de ser con intervención del guarda puesto por la Real Audiencia, D. Francisco Tomás, y han de ser de los árboles más retuertos e inútiles, y que deberá presentar la licencia a esta Junta cuando traiga la leña.

Memorial de D. ${ }^{a}$ Antonia Trenzado, vecina de Tejeda, para sacar del Pinar ciento cincuenta jubrones, treinta tosas y treinta y cinco vigas para fabricar unas casas, cocina y demás. Se acordó no haber lugar respecto a lo desorbitado y que, expresadas las piezas que va a fabricar con lista jurada del carpintero que haya de fabricar la casa, se dará providencia.

\section{1}

\section{3/Julio/10. Canaria.}

Junta con asistencia de D. Manuel del Río y D. Isidoro Romero, regidores perpetuos, y D. Andrés Cabrera, diputado.

Entró el receptor D. Fernando de Quintana y leyó y notificó el auto siguiente de la Real Audiencia:

Canaria y Julio, diez, de mil setecientos noventa y tres años. Los señores, estando en su Real Acuerdo, dixeron que la Junta de montes inmediatamente haga suspender la corta de madera, recoja la lizencia concedida a don Luis Berneta, la entregue en esta Real Audiencia, donde dicho Berneta y Don Lorenzo Sanqui usen de su derecho.

Y se acordó cumplir y guardar dicho mandato, notificando a D. Luis Verneta por el escribano que en tercer día exhiba la licencia en esta Junta, despachando sin pérdida de tiempo persona que haga suspender el corte de madera que se le concedió. 
142

$1793 /$ Julio/11. Canaria.

Junta con asistencia de D. Manuel del Río y D. Isidoro Romero, regidores perpetuos.

Se vio el acuerdo celebrado por el Ayuntamiento en primero del corriente por el que sirvió nombrar por señores diputados de Junta en propiedad a D. Manuel del Río y, en lugar de D. Andrés Barreto, al señor D. Agustín Márquez Romero, precedida la aprobación de la Real Audiencia, donde visto este día se hubieron por nombrados a dichos señores.

Se acordó obedecer al tribunal y quedar enterada.

143

1793/Julio/ 13. Canaria.

Junta con asistencia de D. Manuel del Río y D. Isidoro Romero, regidores perpetuos, y D. Andrés Cabrera, diputado. Citado D. Agustín Romero.

En esta junta exhibió D. Luis Verneta la licencia que se le había concedido obedeciendo el acuerdo de la celebrada en 10 del corriente. Y se acordó se pase en el correspondiente oficio por D. Manuel del Río a la Real Audiencia en cumplimiento de su auto.

\section{4}

1793/Julio/29. Canaria.

Junta con asistencia de D. Manuel del Río y D. Isidoro Romero, regidores perpetuos, y D. Andrés Cabrera, diputado, y D. Agustín Romero.

Haviéndose tratado y conferido sobre los perjuicios que se están siguiendo a la Montaña de Oramas en su de[s]población por causa de que los actuales guardas no zelan ni cumplen con los articulos de sus respectibas instrucciones, pues al paso que el de la parte de Teror tiene un suegro y cuñado fragueros que acaso por su respecto harán talas muy perjudiciales, y que además destrosan este como los otros dos a don Diego de Medina por la parte de Arucas y Juan Martín por la parte de Guí, sin embargo de estar tocando la Junta la saca de maderas, no dan denuncias algunas, de que previene el poco respecto que se tiene a las ordenanzas y penas impuestas a los taladores. $Y$ sin ser visto perjudicar a los tales en manera alguna en sus prosedimientos, dejándolos en buena opinión y fama en desempeño de sus encargos, los que componen esta Junta acordaron removerlos y nomvrar en su lugar, atento a los ynformes que han tomado de su integridad, zelo y desinterés a don Juan del Sar, por la parte de Guí; por la de Teror a Blas Rodríguez, vecino del Palmar; y por la de Arucas, a Juan Marrero Falcón, consultándose con el superior tribunal de la Real Audiencia para su aprovación.

El escribano mayor de Cabildo presentó veinte denuncias dadas por el sobreguarda puesto por la Real Audiencia, D. Francisco Tomás Hernández, de distintos sujetos que encontró cortando leña en la Montaña de Doramas, siete de Teror, cuatro de Moya, dos de Fontanales, cuatro de Gáldar y tres de Guía. Se acordó pasen al alcalde mayor para que proceda contra ellos y se haga representación a la Real Audiencia para que la parte de multas que tocan a 
los propios se entregue a la Junta, para con ellas pagar los gastos de replantos y demás que se ofrezcan.

\section{5}

\section{3/Agosto/9. Canaria.}

Junta con asistencia de D. Manuel del Río y D. Isidoro Romero, regidores perpetuos, y D. Andrés Cabrera, diputado, y D. Agustín Romero.

D. Manuel del Río manifestó un oficio remitido por D. Juan Sall, administrador de reales rentas, que es el siguiente:

Muy ylustres señores. Por el adjunto oficio se instruirá vuestra señoría de lo que me manifiesta el provechedor de la tropa de esta ysla en rasón de prohivirselo por los guardas de la Montaña [de] Doramas a José Gonsález y Francisco Arencivia, condu[c]tores de la leña para la provición de dicha tropa su saca, por cuya razón se carese de este tan preciso abasto y más en las presentes circunstancias, que es necesario tenerlo de respuesto para hechar mano de él, asi en esta ciudad como en la parte donde se ne[ce]cite. En esta inteligencia espero que, continuando vuestra señoría con su acreditado celo al real servicio se cirvirá acordar que dichos guardas no pongan impedimento a los enunciados José Gonsález y Francisco Arencivia a el corte y saca de la leña necesaria para el habasto indispenzable de la tropa de aquellas partes donde la Junta tenga por conveniente, cuyas providencias requieren la mayor breveda[d] a causa de la falta que se experimenta en la provincia. Dios guarde a vuestra señoría muchos años. Palmas de Canaria, y Agosto 9, de mil setecientos nobenta y tres años. Juan Antonio Sall. Muy ylustres señores en Junta de Montes.

Se acordó se conteste al susodicho, con testimonio de este acuerdo, por el señor D. Manuel del Río, insinuándole que esta Junta está pronta y conforme en conceder el corte y saca de leña que se necesite para los fines expresados, pero que para esto, en consecuencia de lo que dispone la ordenanza municipal y reales instrucciones, es indispensable que por el dicho proveedor se pida la correspondiente licencia de las cantidades de leña que necesita para repuesto y consumo de la referida tropa.

\section{6}

\section{3/Agosto/17. Canaria.}

Junta con asistencia de D. Manuel del Río y D. Isidoro Romero, regidores perpetuos, y D. Agustín Romero. Ausente D. Andrés Cabrera.

El receptor Fernando de Quintana hizo saber un decreto de la Real Audiencia fechado el 3 de agosto de 1793 por el que se aprueba el nombramiento de guardas hecho por la Junta de Montes. Y se acordó se guarde, cumpla y ejecute, y se haga saber a los guardas que acudan a la ciudad a realizar el juramento de estilo y recibir el testimonio de sus obligaciones y a los que han estado ejerciéndolo para que entreguen sus títulos y se separen de continuar en estos cargos.

Haviendo entendido la Junta por noticias positivas de que se [h]a pegado fuego en la Montaña de Oramas sin que los guardas, como hera de su hobligación, hayan dado parte a la Junta, se acordó se dé parte de esta novedad con 
testimonio deste acuerdo al señor alcalde maior por medio del señor don Agustín Márquez a fin de que se sirva tomar todas las providencias más conformes a la conservación de los montes.

\section{7}

1793/Agosto/23. Canaria.

Junta con asistencia de D. Manuel del Río y D. Isidoro Romero, regidores perpetuos, y D. Andrés Cabrera, diputado, y D. Agustín Romero.

En esta Junta el señor D. Andrés Cabrera exhibió la representación siguiente sobre la Montaña de Doramas:

Dize que, de resultas de la deboración que hizo el fuego en la Montaña [de] Doramas desde la tarde del dia catorze del corriente hasta la mañana del diez y seis que estuvo ardiendo, pasó el señor exponente a ella y la registró en el modo que pudo, y la encontró en un estado tan deplorable que pareze imposible de que vuelba a su ser primero. No se contrahe el que expone al ser que tenía en lo antiguo, que por tradición save era superior a otro, y si al que le conosió habrá veinte años, desde cuyo tiempo hasta el presente la han tratado con ánimo de //373rto destruirla, porque en aquella era una delicia el ver su frondosidad y espesura pero en este una total desolación. Ella se serró hay pocos años vedando el corte en su mitad y permitiendo este, aunque con el arreglo devido en la otra mitad. Pero qué dolor no causa, señores, al ver el estado en que [h]an dejado esta última porción, quien la vio ahora diez años y la ve en la actualidad es preciso que llore sobre ella. ¿Quien creyera que unos hombres (hablo con los guardas) encargados para su custodia y conserbación permitiesen que a rienda suelta hiziesen tal destrozo? Yo veo en aquel lomo tan espasioso que atrabiesa la Montaña desde Fontanales hasta la Madre de Moya que tiene por nomvre El Peñón, tan celebrado por la hermosura, corpulencia, ma[g]nitud y abundancia de sus árboles, las plazas enteras, todo está destroçado, tal qual árbol antiguo subsiste en él, y el mayor dolor que causa es no haver un retoño ni árbol nuevo que prometa su población.

Ahora se [h] a vedado esta porción y se [ha] abierto la otra mitad, ¿y que se esperará de aqui a mañana de esta? Aseguro que dentro de un año, y aún me alargo, dan con ella en tierra por estado. En ella (que es en donde hizo la deboración el fuego, consumien//373vto do más de doscientas fanegadas) no se encuentra árbol que cortar, todos son renuebos, que es necesario cortar una dozena para hazer una carga de leña; $y$ si estos se permiten reducir a dicha especie, que es lo que se espera, es preciso que vean la extinción dentro de dicho término.

Asimismo, veo que en lo interior de dicha Montaña se está haciendo el carbón. De aqui prosede los insendios quan inculpables con dicho disimulo; toda ella está llena de los hoyos que sirben de horno para su fábrica, permitiendo los guardas este desarreglo, quando se halla prohivido y mandado que se haga en sus orillas distante de los árboles. Que esta fábrica es el enemigo mayor que tiene la Montaña, pues es preciso para sacar una carga de carbón quemar quince o veinte de leña de antes nuestros antiguos, tal ves esperimentando que no podía resistir la Montaña esta fábrica sin su ruina cocinaban con leña. Ahora todos lo quieren hacer con carbón. Es presiso que nos incomodemos y se prohiva 
semejante fábrica en dicha Montaña y solo se permita una cosa moderada, señalando el //374rto sitio adonde ban [a] concurrir unos quantos carboneros que se nomvren para que, sacando de la Montaña con las mismas bestias al referido citio aquellos troncos inútiles, lo reduzgan a dicha especie.

Veo igualmente llena de ganados dicha Montaña. A cada paso no se oye sino belidos de las cabras, que es la rosadera mayor de los árboles. Los serdos en bandos sin auganel ${ }^{18}$, comiendo las semillas y havriendo unos hoyos considerables para arrancar las rayses de aquellas que han brotado.

Veo tamvién que los árboles se siente los derriban por el pie para hacer la leña y algún otro palo que necesitan, sin obserbar el método lexítimo, qual es el de cortar los gajos dejando al árbol su horca y pendón.

Es presiso, señores, que procuremos el remediar este daño; renovemos el celo antiguo para su custodia, que se advitrie el mejor remedio de su conservación, porque de lo contrario y permaneciendo en la propia conformidad se verán prezisados nuestros subsesores a sacar nuestros huesos de los osarios para cosinar con ellos por no tener otro arbitrio. Y para ello me parezía conveniente que se tomasen ynformes de todos //374vto los lugares sircunvesinos y de los nuevos guardas de dicha Montaña, que tal ves lo que uno no alcansa lo descubre otro, y con lo que resultase acordar el arreglo más ada[p]table a dicha conservación para que ante todas cosas se dé quenta al superior tribunal de la Real Audiencia para que como tan sabia provea lo más justo.

Habiéndose tratado y conferido sobre esta representación, se acordó que sacándose testimonio de ella, de la representación hecha por el proveedor de la tropa y de las ordenanzas que se le entregan a los guardas al tiempo de su ingreso, se remita a la Real Audiencia a fin de que se sirva unirlas al expediente general que trata sobre carboneros y otros puntos representados por esta Junta y tomar la providencia que sea de su agrado.

\section{8}

1793 / Agosto/30. Canaria.

Junta con asistencia de D. Manuel del Río y D. Isidoro Romero, regidores perpetuos, y D. Andrés Cabrera, diputado. Citado D. Agustín Márquez, se excusó.

D. Fernando de Quintana, receptor de la Real Audiencia, entró y manifestó un decreto que es el siguiente:

Canaria y agosto, veinte $y$ tres, de mil setecientos noventa y tres años. Los señores, estando en su Real Acuerdo dixeron que, por ahora, ninguna persona pueda hacer carbón sin expresa lizencia de la Junta de Montes y a distancia de docientos pasos de la Montaña en el citio que se les señale, pena de quatro años de servicio en el batallón de estas yslas. Y no siendo apto para dicho servicio, de doscientos ducados aplicados a pena de cámara, y gastos de justicia, y en su defecto de quatro años de destierro a una de las islas menores, lo que se publique en los lugares circumbezinos a ella y en esta ciudad para que llegue a noticia de todos.

18 (sic) 
Se acordó se obedece, guarde y cumpla, y en su consecuencia se pase oficio al alcalde mayor por medio de D. Andrés Cabrera para que se sirva mandarlo publicar por bando en los parajes públicos de esta ciudad y pasar las correspondientes órdenes a los alcaldes de los pueblos para que ejecuten lo mismo en sus poblaciones. Y por el escribano se escriban cartas a los guardas y sobreguarda de la Montaña de Doramas para que no permitan hacer carbón a persona alguna a menos que manifieste licencia de esta Junta.

\section{9}

1793 / Septiembre/2. Canaria.

Junta con asistencia de D. Manuel del Río y D. Isidoro Romero, regidores perpetuos, y D. Andrés Cabrera, diputado, y D. Agustín Márquez.

En esta Junta se presentó la carta siguiente:

Teror y agosto, treinta y uno, de mil setecientos noventa y tres. Muy señor mio, remito a vuestra merced esta denuncia de los sugetos que he coxido en la Montaña de Oramas con leña verde para que vuestra merced la presente donde convenga, y son los siguientes: a Juan Antonio Melián, de Arucas, lo coxi el dia veinte y uno con tres cargas de leña verde; a Salvador Falcón, de Arucas del Serrillo, le coxi en el mismo dia; a Salvador Henrriquez, del mismo Arucas Serrillo, en el mismo dia; a Francisco Mathos, de dicho Arucas, en dicho dia. Fue testigo de vista de todos estos sujetos que ban dichos Josef Antonio de Ojeda, que lo llevé conmigo. Más encontré con leña verde el día veinte y seis a Marcos de Santa Anna, vezino del Trapiche, testigo Josef Blanco, que llevé conmigo. Nuestro Señor guarde a vuestra merced muchos años, su más afectísimo y seguro servidor. Blas Rodríguez. Señor don Ysidoro Romero.

Se acordó se exhiba la carta al guarda que comparezca a formalizar las denuncias y jurarlas como es costumbre.

Se acordó que, a la representación acordada y encargada a D. Andrés Cabrera en razón de que la parte que corresponde a los propios en las multas del ramo de montes con arreglo a la ordenanza, sea para fondo de la Junta, y se añada el que la Junta se halla sin libro y no sabe de qué fondo sacar el costo del que se ha de hacer nuevo.

\section{0}

\section{3/Septiembre/5. Canaria.}

Junta con asistencia de D. Manuel del Río y D. Isidoro Romero, regidores perpetuos. Citados D. Andrés Cabrera, diputado, y D. Agustín Márquez.

Se vio un auto de la Real Audiencia:

En Canaria a veinte $y$ tres de julio de mil setecientos noventa y tres años. Los señores presidente, rexente e oydores, haviendo visto el expediente obrado en razón de la lizencia concedida por la Junta de Montes a don Luis Berneta, vezino de esta ciudad, para el corte de maderas en el Pinar para la nueba construc/clión de un bergantín en las riberas de esta ciudad en lugar del que naufragó del tiempo de su bote con los demás que se tubieron presentes, dixeron que, afianzando don Luis Berneta los derechos que deba pagar por el corte de 
la madera conforme al arreglo que establezerá el tribunal, resolviendo la consulta que sobre el particular tiene echa la Junta de Montes, corra la lizencia concedida por esta del número de árboles que expresa la lista presentada poniendo a su respaldo el guarda el número de árboles que se huviese para ello cortado o se cortasen, con aperzivimiento de que de no hacerlo con toda integridad se procederá a la que huviese lugar. La Junta suspenderá conceder lizencia para corta de madera sin consulta del tribunal por ahora, entre tanto que se forma el referido arreglo, para lo qual se traiga el expediente, y lo rubricaron. Don Josef Antonio Pérez."

Memorial dado por el proveedor de la tropa de esta isla, Pedro Alcántara Déniz, señalando que desde el 19 de agosto había pedido licencia para cortar y sacar de la Montaña de Doramas noventa cargas de leña mensuales para el consumo de dicha tropa, a la cual se acordó que se consultase con el tribunal de la Real Audiencia, uniéndola a otra que se hizo sobre la conservación de dicha Montaña, pero que esto ha sido causa del retraso y multas que se han impuesto a sujetos que han cortado leña por el elevado consumo que tiene la tropa, por lo que suplica una pronta providencia sobre el asunto en atención a la urgencia que lleva expuesta y porque se aproxima el invierno, por lo cual necesita hacer acopio y provisión de leña. Se acordó que, por estar el recurso pendiente en la Real Audiencia, se remite este memorial a esa superioridad para que sobre ello de la providencia que sea de su agrado.

\section{1}

1793/Septiembre/9. Canaria.

Junta con asistencia de D. Manuel del Río, regidor perpetuo, y D. Andrés Cabrera, diputado. Citado D. Agustín Márquez y D. Isidoro Romero, en el campo.

Se vio un certificado dado por el escribano de cámara, D. Juan Reyes de Cabrera, en que manifiesta en él un decreto de la Real Audiencia. que es el siguiente:

Don Juan Reyes de Cabrera, escribano de cámara de la Real Audiencia de estas yslas, y que despacho los negocios del Real Acuerdo por impedimento de don Josef Antonio Pérez, que lo es propietario. Certifico, hago fe y verdadero testimonio que, haviéndose remitido a dicho Real Acuerdo el recurso hecho en la Junta de Montes de esta ysla por parte del provehedor de la tropa de ella, solicitando se consediese lizencia a Josef Gonsález y Francisco Arencivia, condutores de leña, para la saca de la correspondiente a dicha provición sobre lo que en nueve de agosto próximo pasado, acordó dicha Junta hallarse pronta y conforme en conseder el corte y saca de leña que se nesecitase para dicho fin, presentando el provehedor en la Junta solicitando las lizencias que nesecitase, en cuyo particular repitió ynstancia dicho provehedor en Junta de cinco del corriente que por testimonio remitió al Real Acuerdo el comicionando de dicha Junta don Augustín Andrés Márques Romero con representación del día de ayer. Con vista todo se proveyó por la superioridad el decreto siguiente: Canaria, y septiembre, siete, de mil setecientos noventa y tres años. Los señores, estando en su Real Acuerdo digeron que se aprueba el acuerdo celebrado por la Junta de Montes en nueve de agosto próximo, y en su consequencia esta 
proseda a expedir la lizencia para sacar de leña que se solicita por el provehedor de la tropa, según que todo ello asi consta y parese de dicho expediente a que me remito. Y lo firmó en Canaria, a siete de septiembre de mil setecientos noventa y tres años. Don Juan Reyes de Cabrera."

$\mathrm{Y}$ en su vista se aguarde y cumpla y ejecute lo contenido, y se despache la competente licencia.

Se vio una representación dada por D. Juan del Saz, teniente capitán del regimiento de milicias provinciales de Guía, como guarda nombrado de la Montaña de Doramas, en el que señala que se le hizo nombramiento de guarda de la Montaña de Doramas por la parte de Guía; y como es imposible dar cumplimiento a ese encargo debido a los muchísimos y graves negocios de mi casa que debe atender, suplica se le exonere del referido encargo. Se acordó se llame a Junta para el día mañana 10 del corriente.

\section{2}

\section{3/Septiembre/11. Canaria.}

Junta con asistencia de D. Manuel del Río, regidor perpetuo, y D. Andrés Cabrera, diputado, y D. Agustín Márquez. Y D. Isidoro Romero, en el campo.

En esta Junta, habiéndose advertido que los señores que la componen, con motivo de ir a firmar la licencia concedida y aprobada por la Real Audiencia para el proveedor de la tropa para el gasto y consumo de la leña que para ella se necesita, ser excesiva porción de noventa cargas que mensualmente pide, se acordó se haga saber al proveedor de dicha tropa presente en esta Junta lista jurada del consumo que se distribuye con la tropa, y hecho se dará providencia.

Habiéndose tratado sobre el memorial presentado por D. Juan del Saz, teniente capitán del regimiento de milicias provinciales de Guia, extendido en la junta anterior, se acordó que, en atención a que la Junta no atiende otra cosa que a la conservación y aumento de los montes y que según los informes de que se halla instruida no encuentra otro sujeto más activo para desempeñar el encargo de guarda, y manifestar no poder por sí solo dar cumplimiento con la pureza debida a dicho encargo, deseando se le ponga un sustituto que le ayude a llevar la cargas, con cuyas cualidades aceptará el encargo, se le concede amplia facultad para que elija una persona de su satisfacción para que tenga las mismas facultades que los demás guardas, proponiendo antes a esta Junta la persona que elija para que, siendo de su satisfacción, se le nombre en el encargo, todo lo cual se haga presente a la Real Audiencia para su aprobación.

Memorial de D. Juan Rivero, vecino de Guía, para sacar de la Montaña de Doramas doscientos aperos, veinte jubrones y cien tijeras para embarcar para la isla de Fuerteventura por carecer de toda especie de maderos; se acordó no ha lugar a la solicitud y se escriba carta secreta a D. Juan del Saz para que indague si se halla ya cortada la madera expresada, dando aviso a esta Junta de lo que haya bajo el mismo secreto. 


\section{3 \\ 1793/Septiembre/16. Canaria.}

Junta con asistencia de D. Manuel del Río, regidor perpetuo, y D. Andrés Cabrera, diputado. Citado D. Agustín Márquez.

Memorial de Pedro Alcántara Déniz, proveedor de la tropa de esta isla:

Rasón jurada en toda forma de la leña que se nesesita para el mensual consumo de la tropa de esta ysla. Para ciento veinte y quatro hombres de que se compone el destacamento de ynfantería se necesitan indispensablemente de trescientos setenta y dos arrovas, que a quatro arrovas cada carga hacen noventa y tres cargas. Para quinse plasas de la partida de instrución de este reximiento, al mismo respecto onse y una. Para trese plazas de artilleros al propio respe[c]to, nueve y tres. Ymporta la leña que se debe consumir en esta provisión ciento catorse cargas mensuales, además de lo qual se deve tener en consideración que, para el ynbierno que se aproxima, se nesesita haser la suficiente prevención de ella, y no tan solamente por dicho respeto sino por el de qualquier contingencia que acontesía en que se aumente el número de gente, por todo lo qual no solo se nesesitan las referidas ciento y catorse cargas mensuales sino algunas más para los fines expresados, como todo lo juro en forma en virtud de la notificación que se me ha hecho por el escribano de la Junta de Montes del acuerdo de dicha Junta de once del corriente. Canaria, septiembre, dies y seis de mil setecientos noventa y tres años. Pedro Alcántara Díaz. Se acuerda que, por ahora, corra la licencia de noventa cargas de leña mensuales que están concedidas.

Memorial de Juan Mújica, vecino de Moya, para sacar de la Montaña de Doramas leña para hacer carbón, retirados los doscientos pasos según está mandado y en el paraje más oportuno que se le señale según lo prevenido en el bando. Se acordó que los guardas informen señalando el sitio más adaptable y proporcionado para la fábrica de él y remitirán listas de los sujetos que se ocupan en este ejercicio, poniendo al margen de ella los que sean más íntegros en este oficio y se pase oficio suplicando al Ayuntamiento a fin de que se sirva señalar el precio a que se debe vender cada saca de carbón por medio del señor D. Andrés Cabrera.

Se presentó una certificación dada por José Martel Monzón expresando que, habiendo pasado a la playa, encontró una partida de leña de sabina y que era de Francisco José, vecino de Telde. Se acordó se llame a Junta. 